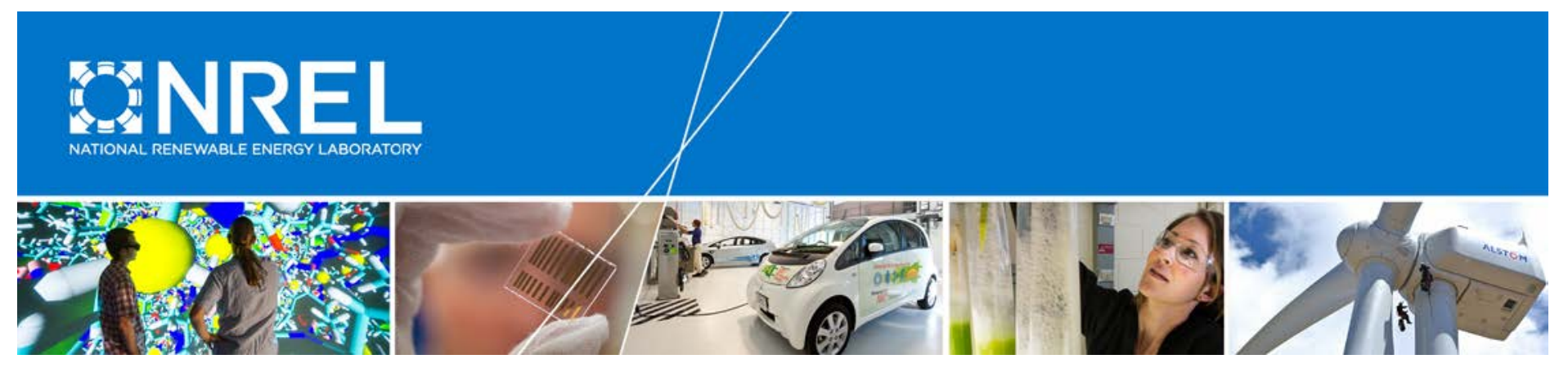

\title{
New York Solar Smart DG Hub- Resilient Solar Project: Economic and Resiliency Impact of PV and Storage on New York Critical Infrastructure
}

Kate Anderson, Kari Burman, and Travis Simpkins National Renewable Energy Laboratory (NREL)

Erica Helson, Lars Lisell, and Tria Case City University of New York (CUNY)

NREL is a national laboratory of the U.S. Department of Energy Office of Energy Efficiency \& Renewable Energy Operated by the Alliance for Sustainable Energy, LLC

This report is available at no cost from the National Renewable Energy Laboratory (NREL) at www.nrel.gov/publications.

Technical Report

NREL/TP-7A40-66617

June 2016 


\section{New York Solar Smart DG Hub- Resilient Solar Project: Economic and Resiliency Impact of PV and Storage on New York Critical Infrastructure}

Kate Anderson, Kari Burman, and Travis Simpkins National Renewable Energy Laboratory (NREL)

Erica Helson, Lars Lisell, and Tria Case City University of New York (CUNY)

Prepared under Task No. WTLU.1000

NREL is a national laboratory of the U.S. Department of Energy Office of Energy Efficiency \& Renewable Energy Operated by the Alliance for Sustainable Energy, LLC

This report is available at no cost from the National Renewable Energy Laboratory (NREL) at www.nrel.gov/publications.

National Renewable Energy Laboratory 15013 Denver West Parkway Golden, CO 80401

303-275-3000 • www.nrel.gov
Technical Report

NREL/TP-7A40-66617

June 2016

Contract No. DE-AC36-08GO28308 


\section{NOTICE}

This report was prepared as an account of work sponsored by an agency of the United States government. Neither the United States government nor any agency thereof, nor any of their employees, makes any warranty, express or implied, or assumes any legal liability or responsibility for the accuracy, completeness, or usefulness of any information, apparatus, product, or process disclosed, or represents that its use would not infringe privately owned rights. Reference herein to any specific commercial product, process, or service by trade name, trademark, manufacturer, or otherwise does not necessarily constitute or imply its endorsement, recommendation, or favoring by the United States government or any agency thereof. The views and opinions of authors expressed herein do not necessarily state or reflect those of the United States government or any agency thereof.

This report is available at no cost from the National Renewable Energy Laboratory (NREL) at www.nrel.gov/publications.

Available electronically at SciTech Connect http:/www.osti.gov/scitech

Available for a processing fee to U.S. Department of Energy and its contractors, in paper, from:

U.S. Department of Energy

Office of Scientific and Technical Information

P.O. Box 62

Oak Ridge, TN 37831-0062

OSTI http://www.osti.gov

Phone: 865.576.8401

Fax: 865.576.5728

Email: reports@osti.gov

Available for sale to the public, in paper, from:

U.S. Department of Commerce

National Technical Information Service

5301 Shawnee Road

Alexandria, VA 22312

NTIS http://www.ntis.gov

Phone: 800.553 .6847 or 703.605 .6000

Fax: 703.605.6900

Email: orders@ntis.gov 


\section{Acknowledgments}

This work was sponsored by the U.S. Department of Energy under a Solar Market Pathways grant. The New York City Department of Citywide Administrative Services (DCAS), New York City Housing Authority, Fire Department of New York, New York Department of Education, New York City Emergency Management, New York Power Authority, Con Edison, and BlocPower were instrumental in providing data for the analysis and hosting site visits. We would like to acknowledge Dylan Cutler and Dan Olis of NREL for their role in developing the stochastic outage modeling capability in REopt. We would also like to thank Bob Butt and Dan Olis of NREL, Jeff Irvine and Allison Silverman of CUNY, Ellen Zielinski, Steve Lochner and Hamid Lekic of DCAS, Doug Staker of Demand Energy, Henry Misas of Bright Power, Cynthia Barton of New York City Emergency Management, Benjamin Pickard of Peak Power LLC, and the DG Hub Software Working Group members for their input and review of this analysis. 


\section{List of Abbreviations and Acronyms}

\begin{tabular}{|c|c|}
\hline ASHRAE & $\begin{array}{l}\text { American Society of Heating, Refrigerating, and Air- } \\
\text { Conditioning Engineers }\end{array}$ \\
\hline CUNY & City University of New York \\
\hline DC & direct current \\
\hline DCAS & Department of Citywide Administrative Services \\
\hline DOE & U.S. Department of Energy \\
\hline $\mathrm{EC}$ & engine company \\
\hline $\mathrm{EE}$ & energy efficiency \\
\hline FDNY & Fire Department of New York \\
\hline $\mathrm{Ft}$ & feet \\
\hline $\mathrm{Ft}^{2}$ & square feet \\
\hline ICE & interruption cost estimate \\
\hline ITC & investment tax credit \\
\hline K & thousand \\
\hline $\mathrm{kW}$ & kilowatt \\
\hline $\mathrm{kWh}$ & kilowatt-hour \\
\hline LCOE & levelized cost of energy \\
\hline LED & light-emitting diode \\
\hline M & million \\
\hline MACRS & modified accelerated cost recovery system \\
\hline NPV & net present value \\
\hline NREL & National Renewable Energy Laboratory \\
\hline NYC & New York City \\
\hline NYCHA & New York City Housing Authority \\
\hline NYC-DOE & New York City Department of Education \\
\hline NYC EM & New York City Emergency Management \\
\hline NYPA & New York Power Authority \\
\hline NYSERDA & $\begin{array}{l}\text { New York State Energy Research and Development } \\
\text { Authority }\end{array}$ \\
\hline O\&M & operations and maintenance \\
\hline PPA & power purchase agreement \\
\hline PV & photovoltaics \\
\hline RE & renewable energy \\
\hline RPR & reverse power relay \\
\hline SCADA & supervisory control and data acquisition \\
\hline SREC & solar renewable energy credit \\
\hline TOD & time of day \\
\hline $\mathrm{W}$ & watt \\
\hline
\end{tabular}




\section{Executive Summary}

Resilient PV, which is solar paired with storage ("solar-plus-storage") that operates both on and off grid, provides value during normal grid operation and during power outages, as opposed to traditional solar PV, which functions only when the electric grid is operating. During normal grid operations, resilient PV systems help host sites generate revenue and/or reduce electricity bill charges. During grid outages, resilient PV provides critical emergency power that can help people in need and ease demand on emergency fuel supplies. The combination of grid interruptions during recent storms, the proliferation of solar PV, and the growing deployment of battery storage technologies has generated significant interest in using these assets for both economic and resiliency benefits. This report analyzes the technical and economic viability of solar and storage on three critical infrastructure sites in New York City (NYC): a school that is part of a coastal storm shelter system, a fire station that was flooded during Sandy, and a NYCHA senior center that serves as a cooling center during heat emergencies. This analysis differs from previous solar-plus-storage studies by placing a monetary value on resiliency and thus, in essence, modeling a new revenue stream for the avoided cost of a power outage. Analysis results show that resilient PV can be economically viable for NYC's critical infrastructure and that it may be similarly beneficial to other commercial buildings across the city.

This report will help managers of city buildings, private building owners and managers, the resilient PV industry, and policymakers to better understand the economic and resiliency benefits of resilient PV. As NYC fortifies its building stock against future storms of increasing severity, resilient PV can play an important role in disaster response and recovery while also supporting city greenhouse gas emission reduction targets and relieving stress to the electric grid from growing power demands.

This analysis used the REopt modeling platform to optimally select and size resilient power options for the sites in the study. Four scenarios were modeled to reflect different priorities and constraints; each scenario was modeled with and without a resiliency revenue stream. The value of resiliency to a site in this analysis is equal to the estimated costs incurred due to grid interruptions. In each case, the resilient PV system was able to capture revenue streams associated with displacing energy purchases from the grid, reducing peak demand charges, and shifting grid-purchased energy from high to low time-of-use cost periods. In all cases, the model found the combination of energy assets that minimized the life cycle cost of energy for the site.

1. Scenario 1: Resilient PV sized for economic savings; no resiliency requirement imposed The model chose from solar and storage resources to size a system that is cost-effective ${ }^{*}$ for the host site.

2. Scenario 2: Resilient PV sized to meet resiliency needs

The model chose from solar and storage resources to size a system that supports critical electric loads for short and long outages.

3. Scenario 3: Resilient PV and a generator (hybrid system) sized to meet resiliency needs The model chose from solar, storage, and diesel generator resources to size a hybrid system that supports critical electric loads for short and long outages.

\footnotetext{
1 "Cost-effective" in this report means that the modeled system has a life cycle NPV that is equal to or greater than zero.
} 


\section{Scenario 4: Generator sized to meet resiliency needs}

The model sized a diesel generator to support critical electric loads for short and long outages.

The results from the modeling indicate that resilient PV can provide both resiliency and economic benefits for the three sites analyzed in this study. The level of resiliency and/or economic savings the systems will provide depends on a number of factors including:

- Electricity rate of the host site

- Available space to accommodate solar energy

- The combination of technologies used

- The size and shape of the typical load and the critical load

- Whether or not the model includes a monetary value for resiliency.

If a technology solution is being implemented primarily to provide emergency power, the results of the analysis indicate that a hybrid system (Scenario 3) that includes resilient PV and a generator is the most cost-effective technology solution, when measured by lifecycle cost savings. The savings the battery (and sometimes PV) provides during normal grid-connected operation make the hybrid system more economical than a diesel generator alone. However, the hybrid system has a higher initial cost and is more complex than a stand-alone generator.

If lifecycle cost savings is the primary goal, and emergency power is secondary, the results of the study show storage (and sometimes PV) to be the best solution out of the options evaluated for the three sites analyzed under this study. These systems provide maximum cost savings over the project lifecycle with some resiliency benefit. A generator-only solution (Scenario 4), while having the least expensive initial cost, provided lower lifecycle cost savings because this type of asset does not provide value during normal, on-grid operations in this analysis.

The analysis also found that energy storage was cost-effective at all three locations. This is due to the high demand rates and the shape of the load profile at each of these sites. A modestly sized battery system can be strategically charged and discharged such that it shaves the monthly peak loads and therefore captures significant demand savings. It is expected that batteries would also be economically viable at other critical infrastructure sites with high demand rates and similarly shaped load profiles.

The three studied sites are all supplied by NYPA, with Con Edison providing electric delivery services. They have high demand charges and lower-than-average energy costs. For the smaller sites with limited roof space, the model did not always select solar as part of the lowest-cost solution. However, storage savings at these locations were used to offset the cost of solar to demonstrate how these technologies can be used in conjunction to create cost-effective systems. With NYC's commitment to deploying $100 \mathrm{MW}$ of solar on city-owned buildings by 2025, this analysis demonstrates that solar paired with energy storage can support the city's solar deployment goals at buildings where energy costs are low and standalone solar may not always be cost-effective. 
Lastly, the results showed that the inclusion of the cost of power outages can have a large impact on the economic viability of a resiliency solution. The net present value (NPV) of a system was always higher when resiliency was valued. Resiliency values were higher for the radial customer (the fire station in this analysis) which is likely to experience more frequent outages, and lower for the school shelter and cooling center, which are network customers on a more reliable grid. The resiliency value realized by the systems was higher for longer outages because there are more outage costs avoided during a long outage compared to a short outage. Currently, generators are responsible for providing the majority of NYC's emergency power needs during times of disaster. This analysis shows that cost-effective hybrid systems that include resilient PV and a generator can extend limited fuel supplies by reducing fuel consumption by approximately 9-36\%. Furthermore, with and without a resiliency value, a hybrid system provides emergency power to the sites studied in this analysis at the lowest lifecycle cost.

While only three types of critical infrastructure were evaluated in this analysis, similar results could be expected at other critical infrastructure sites with similar loads and utility rate tariffs. Modestly sized resilient PV systems can achieve both economic savings during normal grid operation and limited emergency power supply during outages. When paired with a backup diesel generator, hybrid resilient PV systems can sustain critical loads for short and long outages ( 2 hours up to 2 days were modeled). This analysis is intended to initiate a conversation about the use of resilient PV on city buildings among policymakers who are working to increase resiliency while lowering greenhouse gas emissions and electricity costs. 


\section{Table of Contents}

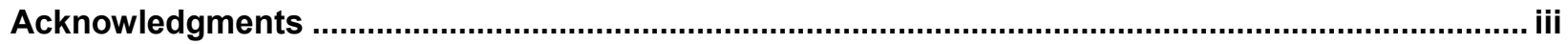

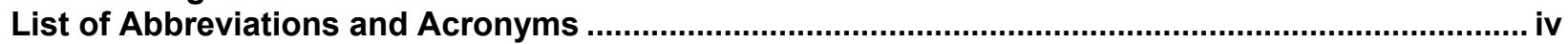

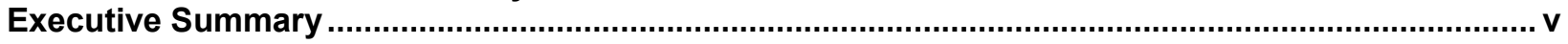

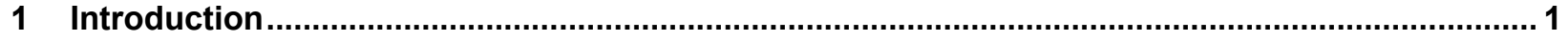

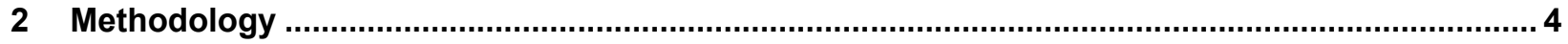

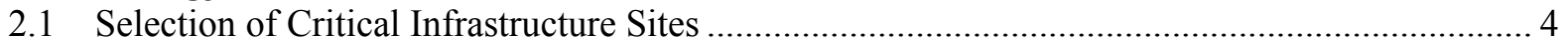

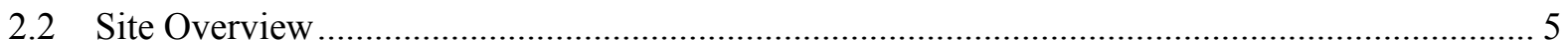

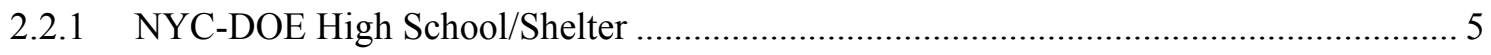

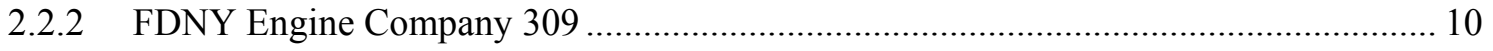

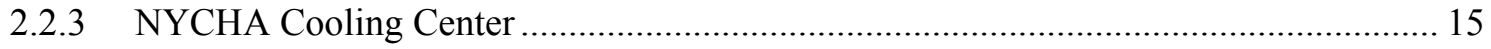

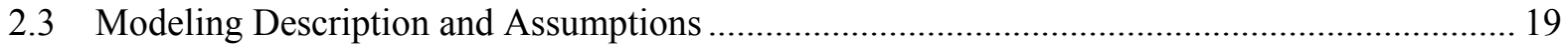

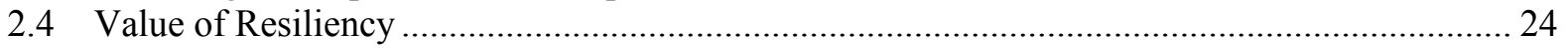

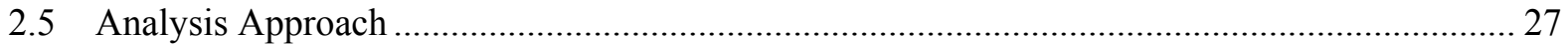

2.5.1 Scenario 1: Resilient PV Sized for Economic Savings; no Resiliency Requirement

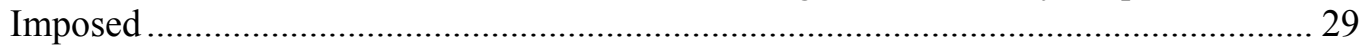

2.5.2 Scenario 2: Resilient PV Sized to meet Resiliency Needs ........................................... 29

2.5.3 Scenario 3: Resilient PV and a Generator (Hybrid System) Sized to meet Resiliency

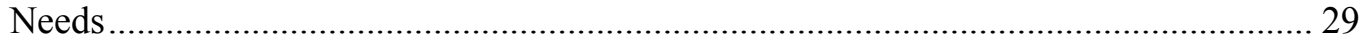

2.5.4 Scenario 4: Generator Sized to meet Resiliency Needs ................................................ 30

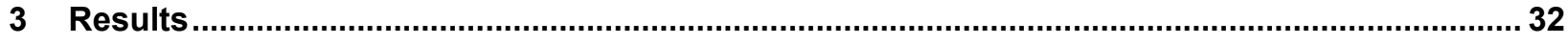

3.1 NYC-DOE High School/Coastal Storm Shelter................................................................... 32

Scenario 1: Resilient PV Sized for Economic Savings; no Resiliency Requirement

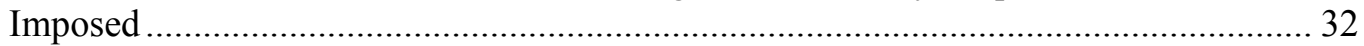

Scenario 2: Resilient PV Sized to meet Resiliency Needs ....................................................... 35

Scenario 3: Resilient PV and a Generator (Hybrid System) Sized to meet Resiliency Needs .... 36

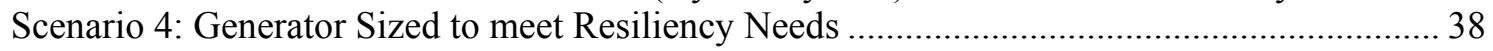

Discussion of School Shelter Results Across All Scenarios................................................. 38

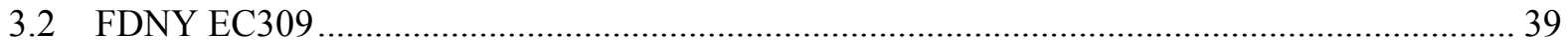

Scenario 1: Resilient PV Sized for Economic Savings; no Resiliency Requirement Imposed ... 39

Scenario 2: Resilient PV Sized to meet Resiliency Needs ....................................................... 41

Scenario 3: Resilient PV and a Generator (Hybrid System) Sized to meet Resiliency Needs .... 42

Scenario 4: Generator Sized to meet Resiliency Needs ............................................................ 43

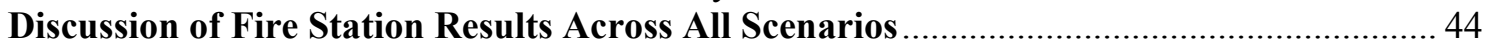

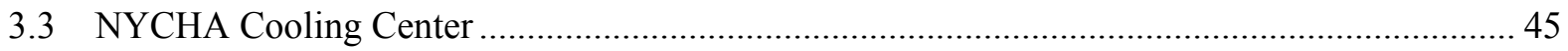

Scenario 1: Resilient PV Sized for Economic Savings; no Resiliency Requirement Imposed ... 45

Scenario 2: Resilient PV Sized to meet Resiliency Needs ....................................................... 47

Scenario 3: Resilient PV and a Generator (Hybrid System) Sized to meet Resiliency Needs.... 48

Scenario 4: Generator Sized to meet Resiliency Needs ......................................................... 49

Discussion of Cooling Center Results Across All Scenarios ............................................ 50

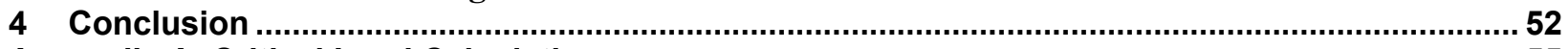

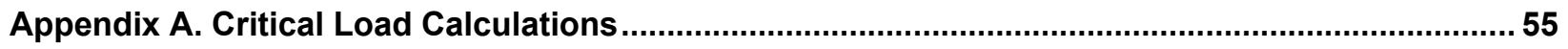

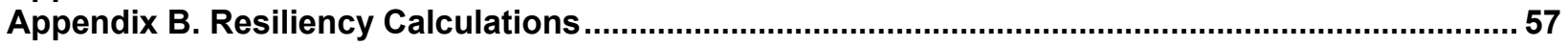

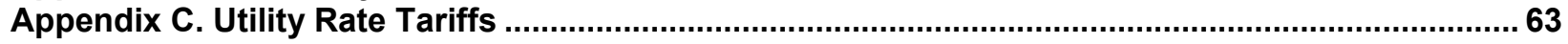

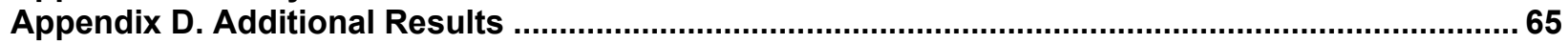

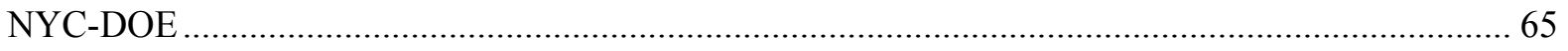

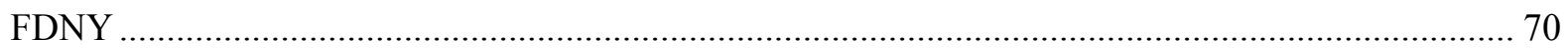

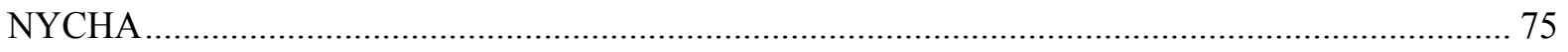




\section{List of Figures}

Figure 1. Susan Wagner High School

Figure 2. Susan Wagner High School annual energy profile 2014-2015 ......................................... 6

Figure 3. Susan Wagner High School composite daily load profile .................................................... 6

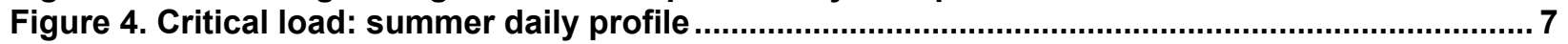

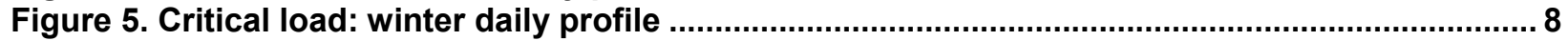

Figure 6. Critical load: shoulder season daily profile ................................................................. 8

Figure 7. Susan Wagner High School/Shelter PV layout ............................................................ 9

Figure 8. Roof of the Susan Wagner High School, looking south in Area 1 ...................................... 9

Figure 9. FDNY EC309 in Marine Park........................................................................................ 11

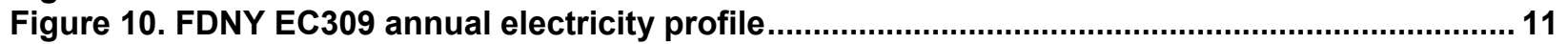

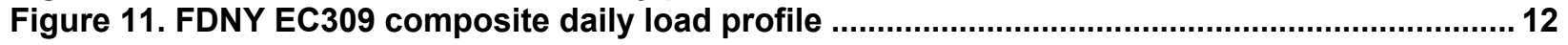

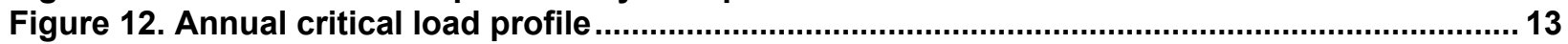

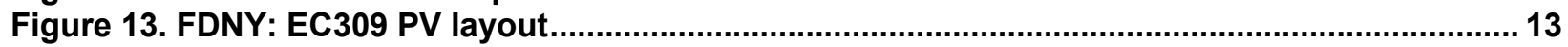

Figure 14. Roof of the fire station looking east from the west side ................................................. 14

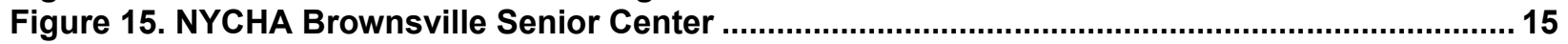

Figure 16. NYCHA Brownsville Senior Center annual load profile ................................................ 16

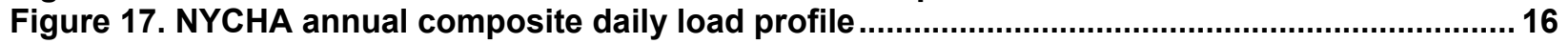

Figure 18. NYCHA Brownsville Senior Center daily critical load profile .......................................... 17

Figure 19. NYCHA Senior Center PV layout .............................................................................. 18

Figure 20. Roof of the NYCHA Senior Center/Cooling Center looking south ................................... 18

Figure 21. Screenshot of DOE ICE Calculator inputs............................................................... 25

Figure 22. Con Edison system-wide grid reliability with storms ................................................. 25

Figure 23. PV and battery combine to reduce peak demand........................................................... 33

Figure 24. PV and battery support the critical load during a 51-hour outage ................................. 36

Figure 25. PV and battery reduce the size of generator required to meet the critical load during a 51-

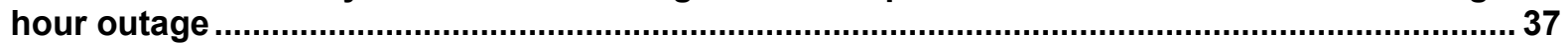

Figure 26. PV and battery combine to reduce peak demand at the fire station ..............................40

Figure 27. During a 21-hour grid outage on September 7th, the PV (orange) and battery (green) sustain

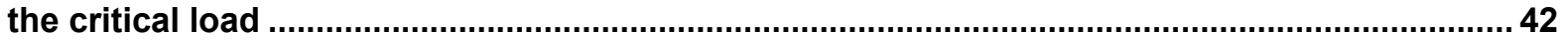

Figure 28. During a 21-hour grid outage on September 7th, the PV (orange) and battery (green) meet peak loads to reduce the size of generator required to sustain the critical load ..........................43

Figure 29. The battery (green) is discharged in the evening to shave the peak demand .................46

Figure 30. During a 51-hour grid outage in August, PV production is marginal and the battery (green)

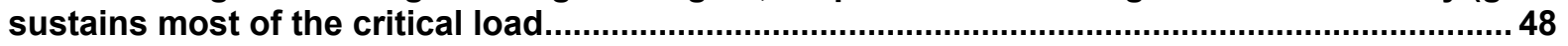

Figure 31. During the 51-hour outage in August, the PV and battery reduce the size of diesel generator required to meet the critical load, as well as reducing run-time of the diesel generator ............49

Figure B-1. Outputs from the ICE Calculator for the Fire Station .................................................... 57

Figure B-2. Cost vs. Outage Length from the ICE Calculator for the Fire Station ............................58

Figure B-3. Outputs from the ICE Calculator for the NYCHA Cooling Center ...................................59

Figure B-4. Cost vs. Outage Length from the ICE Calculator for the Cooling Center ........................60

Figure B-5. Outputs from the ICE Calculator for the School Shelter................................................61

Figure B-6. Cost vs. Outage Length from the ICE Calculator for the School Shelter........................62

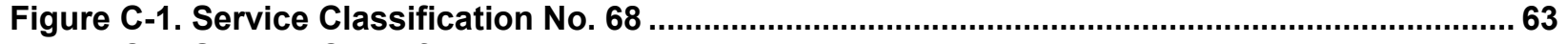

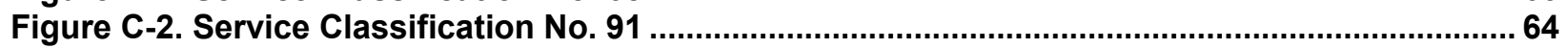




\section{List of Tables}

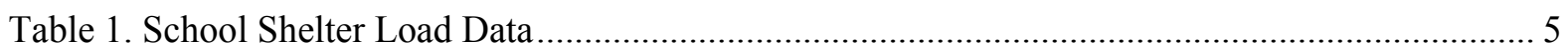

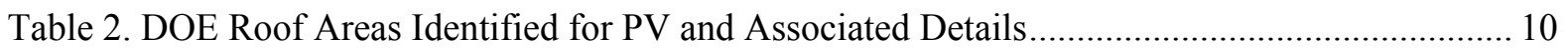

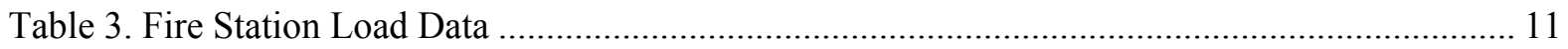

Table 4. FDNY Roof Areas Identified for PV and Associated Details ............................................ 14

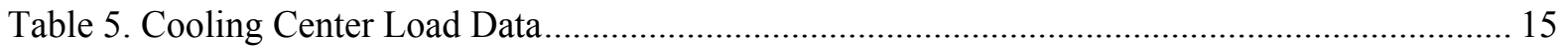

Table 6. NYCHA Roof Areas Identified for PV and Associated Details......................................... 19

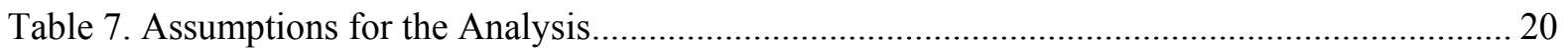

Table 8. Con Edison Five-Year Average SAIFI Values for Radial and Network Customers.............. 26

Table 9. Con Edison CAIDI Values for Radial and Network Customers ........................................26

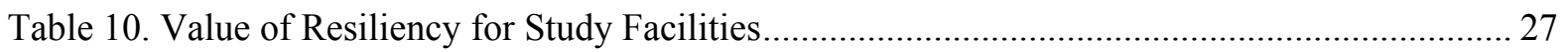

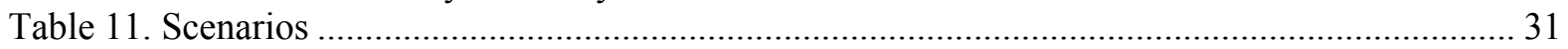

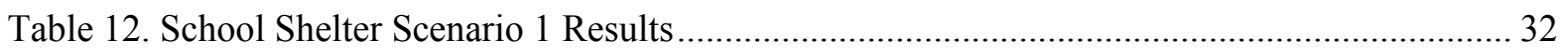

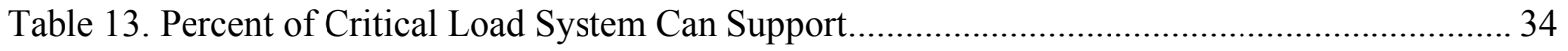

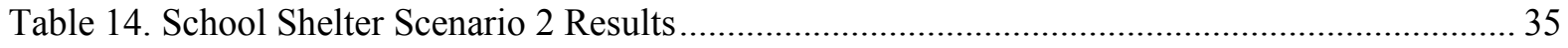

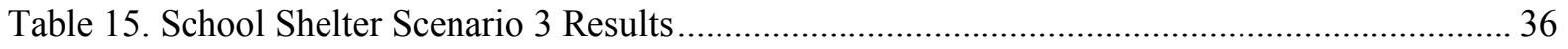

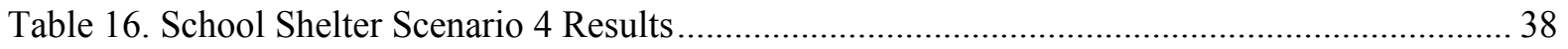

Table 17. School Shelter NPV and Payback Comparison of Scenarios 2, 3, and 4 ........................... 39

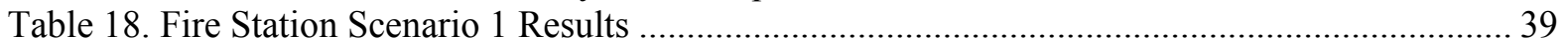

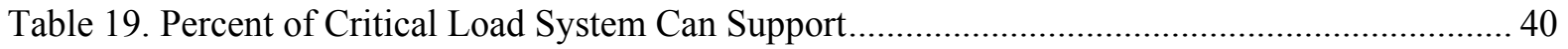

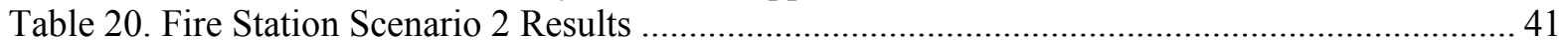

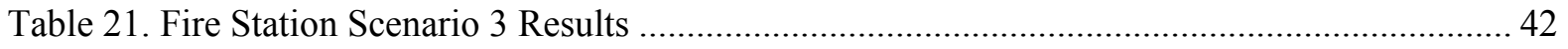

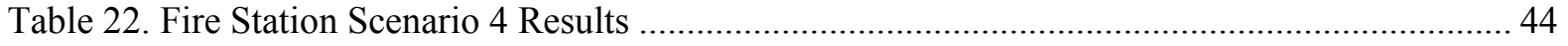

Table 23. Fire Station NPV and Payback Comparison of Scenarios 2, 3, and 4 ............................... 44

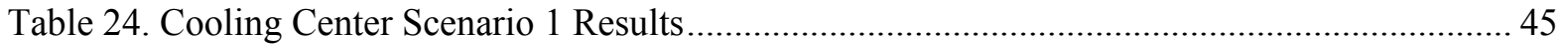

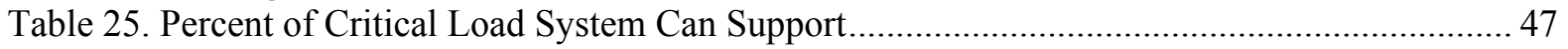

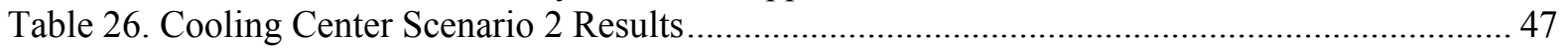

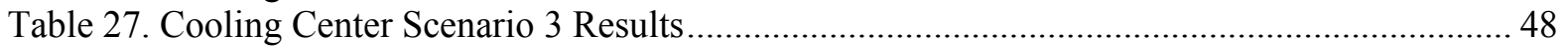

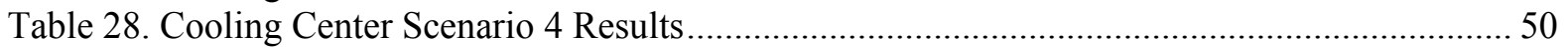

Table 29. Cooling Center NPV and Payback Comparison of Scenarios 2, 3, and 4 ........................ 51

Table A-1. NYCHA Cooling Center Daily Critical Load During the Summer .................................. 55

Table A-2. NYC-DOE School Shelter Daily Critical Load During the Summer and Winter .............. 56

Table B-1. Outputs from the ICE Calculator for 1-16 Hour Outages (in 60-Minute Increments) for the

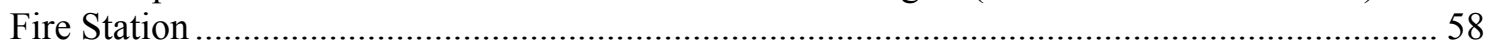

Table B-2. Outputs from the ICE Calculator for 1-16 Hour Outages (in 60-Minute Increments) for the

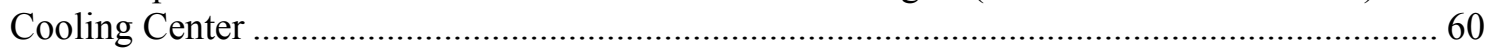

Table B-3. Outputs from the ICE Calculator for 1-16 Hour Outages (in 60-Minute Increments) for the

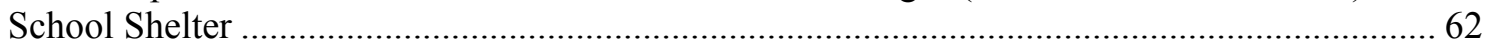

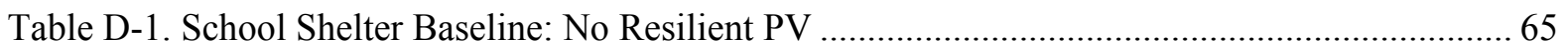

Table D-2. School Shelter Scenario 1: Resilient PV Sized for Economic Savings...............................66

Table D-3. School Shelter Scenario 2: Resilient PV Sized to Meet Resiliency Needs ........................ 67

Table D-4. School Shelter Scenario 3: Resilient PV and Generator (Hybrid System) Sized to Meet

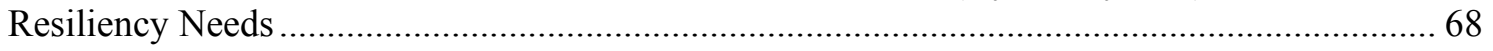

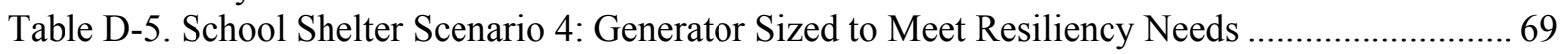

Table D-6. Fire Station Baseline: No Resilient PV .......................................................................... 70

Table D-7. Fire Station Scenario 1: Resilient PV Sized for Economic Savings ................................. 71

Table D-8. Fire Station Scenario 2: Resilient PV Sized to Meet Resiliency Needs............................ 72

Table D-9. Fire Station Scenario 3: Resilient PV and Generator (Hybrid System) Sized to Meet

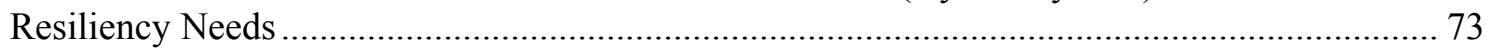

Table D-10. Fire Station Scenario 4: Generator Sized to Meet Resiliency Needs ............................... 74 
Table D-11. Cooling Center Baseline: No Resilient PV .....

Table D-12. Cooling Center Scenario 1: Resilient PV Sized for Economic Savings.......................... 76

Table D-13. Cooling Center Scenario 2: Resilient PV Sized to Meet Resiliency Needs ..................... 77

Table D-14. Cooling Center Scenario 3: Resilient PV and Generator (Hybrid System) Sized to Meet

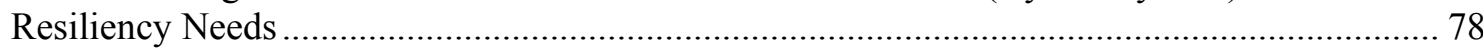

Table D-15. Cooling Center Scenario 4: Generator Sized to Meet Resiliency Needs ........................ 79 


\section{Introduction}

Electricity system resiliency focuses on preventing power disruption and, when an outage does occur, restoring electricity supply as quickly as possible while mitigating the consequences of the outage. Resiliency in energy services has always been a top priority, especially for critical or high-value facilities such as emergency response centers, hospitals, and shelters. Currently, diesel or gas-powered generators are relied upon for the majority of emergency power needs, though renewable energy and other forms of distributed generation are starting to play a role in energy resiliency. ${ }^{2}$

The United States has seen an increase in the number of high-impact/high-cost natural disasters - seven of the ten costliest storms in U.S. history have occurred in the last ten years. ${ }^{3}$ These high-impact events have sometimes resulted in widespread and long outage durations, demonstrating that existing approaches to energy resiliency were not sufficient in some cases. This was due to a number of factors including lack of generators or other forms of backup power; lack of refueling options for backup diesel generators; unreliable operation of backup generators; interruptions in natural gas and other fuel supplies; and aging infrastructure.

According to the NYC Hurricane Sandy After Action Report, the need for generators after the storm far exceeded the available supply. The city deployed approximately 230 generators in total. ${ }^{4}$ Even when they were available, generators failed at several high-profile hospitals in NYC after the storm and called attention to the fact that the presence of a generator does not ensure emergency power. Generators are more susceptible to failure when equipment is outdated, improperly maintained, placed in flood-prone basements, or when fuel supplies are limited. ${ }^{5}$ NYC codes limit onsite fuel storage for tank-based diesel generators to 250 gallons. ${ }^{6}$ For a building with a $200-\mathrm{kW}$ generator operating at half capacity, a 250 -gallon fuel supply would be depleted in just under 30 hours. ${ }^{7}$ The average annual outage duration with storms in NYC over the past 5 years is about 22 hours for affected radial customers and just over 50 hours for affected network customers ${ }^{8}$, but in 2012 (the year of Superstorm Sandy), outage durations

\footnotetext{
2 “Solar + Energy Storage $=$ Resilient Power in Vermont." 2014. Clean Energy Group. http://www.cleanegroup.org/solar-energy-storage-resilient-power-in-vermont/.

${ }^{3}$ Executive Office of the President. 2013. Economic Benefits of Increasing Electric Grid Resilience to Weather Outages. http://energy.gov/sites/prod/files/2013/08/f2/Grid\%20Resiliency\%20Report_FINAL.pdf.

${ }^{4}$ NYC Mayor's Office. 2013. NYC Hurricane Sandy After Action Report. http://www.nyc.gov/html/recovery/downloads/pdf/sandy_aar_5.2.13.pdf.

${ }^{5}$ Ornstein, C. 2012. "Why Do Hospital Generators Keep Failing?” ProPublica. https://www.propublica.org/article/why-do-hospitals-generators-keep-failing.

${ }^{6}$ Fire Department of the City of New York. 2014. Study Material for the Citywide Certificate of Fitness Examination. http://www.nyc.gov/html/fdny/pdf/cof study material/s 94 st mat.pdf.

${ }^{7}$ Based on Cat Model D200-2, a 200-kW generator that is $50 \%$ loaded and uses 8.6 gallons/hour.

${ }^{8}$ There are two types of electric grid systems, radial and secondary network. Radial systems have a single high voltage feeder sending energy from the substation to numerous distribution transformers tapped along it. Cables and transformers on radial grids are often above ground. Network grids have multiple primary feeders feeding several parallel network transformers that feed energy into a low voltage grid (grid network type) or local building bus (spot network) where the consumer is connected. Spot networks are where one or multiple transformers are dedicated to one large energy consuming building. Cables and transformers on network grids are often below ground. Network grids are considered more reliable than radial grids as there are redundant sources of backup power in case of failures on the grid and underground equipment is less prone to weather-related damage.
} 
reached 73 and 58 hours, respectively. ${ }^{9}$ Fuel supply in New York was scarce after Sandy for nearly a month as a result of refineries being shut down and other damages to the fuel supply chain serving New York. ${ }^{10}$ Local supplies were not sufficient to meet needs, resulting in FEMA providing more than 3.48 million gallons of fuel for Sandy recovery at a cost of $\$ 6.37$ million. ${ }^{11}$

Long-duration outages can lead to lost output, wages, and inventory. The estimated cost of U.S. weather-related outages in 2012 is $\$ \mathbf{2 7 - 5 2}$ billion dollars. ${ }^{12}$ For individuals who rely on electronic medical equipment, these outages can be lethal. Adding to costs associated with Superstorm Sandy, NYC was sued for violating the Americans with Disabilities Act, in part for failing to provide adequate emergency power. ${ }^{13}$ The cost of power outages varies from person to person and facility to facility, but the costs are real, and so is the value of avoiding an outage.

Resilient PV can serve as an alternative or supplement to existing forms of backup power, extending limited fuel supplies when paired with generators. A resilient PV system can be operated for economic gain during the $99.9 \%$ of the time that the grid is functional by offsetting bulk energy purchases, reducing peak demand charges, performing energy arbitrage ${ }^{14}$, and providing ancillary services. With appropriate inverters and controls these same systems can be islanded to form a microgrid, often along with diesel generators, to sustain critical electrical loads for the site during grid outages. A hybrid generator/PV/battery system can sustain longer outages for a given amount of diesel fuel by reducing the run-time (and therefore fuel consumption) of the diesel generator, thus increasing the energy resiliency of the site. ${ }^{15}$ For the three sites evaluated in this analysis, the hybrid generator/PV/battery system consumed $9 \%-36 \%$ less fuel than the standalone diesel generator during long outages. Additionally, resilient PV systems may provide a fast-acting backup power supply for small, highly sensitive critical loads like computers or communications equipment. Some resilient PV designs can re-energize critical loads within 10 to 20 milliseconds, compared to generators that may take 3-10 seconds to start.

Standalone resilient PV systems avoid problems associated with generators like noise and air quality issues while offering host sites a cost-savings opportunity and a reduced carbon footprint. Resilient PV hits an intersection point between resiliency and sustainability, two significant areas

9 “Electric Service Reliability Reports.” 2015. New York State Department of Public Service.

http://www3.dps.ny.gov/W/PSCWeb.nsf/All/D82A200687D96D3985257687006F39CA?OpenDocument.

${ }^{10}$ NYC Mayor's Office. 2013. A Strong, More Resilient New York. http://www.nyc.gov/html/sirr/downloads/pdf/final_report/Ch_1_SandyImpacts_FINAL_singles.pdf.

${ }^{11}$ Office of Inspector General. 2015. FEMA Has No Assurance that Only Designated Recipients Received \$6.37 Million in Fuel. Department of Homeland Security. https://www.oig.dhs.gov/assets/GrantReports/2016/OIG-16-04D-Nov15.pdf.

${ }^{12}$ Executive Office of the President. 2013. Economic Benefits of Increasing Electric Grid Resilience to Weather Outages.http://energy.gov/sites/prod/files/2013/08/f2/Grid\%20Resiliency\%20Report FINAL.pdf.

${ }^{13}$ Santora, M., and B. Weiser. 2013. "Court Says New York Neglected Disabled in Emergencies." New York Times. http://www.nytimes.com/2013/11/08/nyregion/new-yorks-emergency-plans-violate-disabilities-act-judge-says.html.

${ }^{14}$ Energy arbitrage is the process of charging batteries when energy prices are low, and discharging them when energy prices are high. This effectively shifts grid energy purchases to periods with lower energy prices.

${ }^{15} 1 \mathrm{~kW}$ of PV in NYC generates $1274 \mathrm{kWh} /$ year, or an average of $0.145 \mathrm{kWh} /$ hour. As previously described, a 200$\mathrm{kW}$ generator that is $50 \%$ loaded requires 8.6 gallons of fuel to generate $100 \mathrm{kWh}$. If the generator fuel curve were linear, a solar system would offset approximately 0.01247 gallons of fuel per hour per $\mathrm{kW}$ of solar installed. In this example, a $100-\mathrm{kW}$ PV system installed alongside the $200-\mathrm{kW}$ generator would displace about $14.5 \%$ of the hourly fuel consumption, saving about 1.25 of the 8.6 gallons used each hour. 
of interest for NYC and much of the country. With the technical analysis offered in this report, those who plan for the city's emergency power needs have a template methodology to compare and contrast resilient power options and the opportunity to deepen collaboration across resiliency and sustainability programs.

Solar installations in New York are increasing rapidly. From 2011 to 2015, solar installations in New York increased $575 \%$, and by $675 \%$ in NYC. ${ }^{16}$ The state is mandated to supply $50 \%$ of its electricity from renewables by 2030 and aims to deploy $3 \mathrm{GW}$ of solar across the state by 2023 . Energy storage can enable higher levels of intermittent renewables like solar, and studies show that the combined value of solar-plus-storage on commercial buildings is higher than deploying the technologies separately. ${ }^{17}$ In NYC, solar increased from a quarter of a megawatt in 2008 to nearly 50 megawatts in 2016, but few of these systems include backup power capabilities either through battery backup or inverters with emergency power plugs. Only a handful of commercialscale solar-plus-storage systems exist in NYC today, and only a few of these systems are configured to provide emergency backup power. With NYC committed to deploy $100 \mathrm{MW}$ of solar on city-owned buildings by 2025, this report highlights the unique opportunity that resilient PV systems can provide for critical infrastructure sites, many of which are owned by the city. The NYSolar Smart Distributed Generation (DG) Hub, through projects like this analysis, is creating pathways for resilient $\mathrm{PV}$ to reach the market. ${ }^{18}$

\footnotetext{
16 “Solar Growth per Region.” 2015. NYSERDA. http://www.nyserda.ny.gov/-/media/Files/About/SUN-GEN-solargrowth-by-region.pdf.

${ }^{17}$ Sussman, M., and J. Lutton. 2015. “The Economics of Solar, Storage and Solar-Plus-Storage.” Greentech Media. http://www.greentechmedia.com/articles/read/The-Economics-of-Solar-Storage-and-Solar-Plus-Storage.

${ }^{18}$ The DG Hub was formed by Sustainable CUNY in the aftermath of Hurricane Sandy, and received funding from the U.S. Department of Energy, NYSERDA, and NYPA in 2015 to work with partners to create strategic pathways for greater resiliency using solar and storage. Additional DG Hub resources can be found at www.cuny.edu/DGHub.
} 


\section{Methodology}

The City University of New York (CUNY) and the National Renewable Energy Laboratory (NREL) worked with city partners to select three critical infrastructure sites at which to evaluate PV and battery opportunities. CUNY and NREL gathered preliminary utility and site data, and verified the data during site assessments. For each of the three critical sites selected, we modeled the economic and resiliency benefits of PV and battery systems at the three sites. This section documents the data collected and assumptions made for the modeling.

\subsection{Selection of Critical Infrastructure Sites}

CUNY and NREL, in coordination with the NYSolar Smart DG Hub software working group, identified a range of critical infrastructure facility types to consider: utilities, coastal storm shelters, transportation systems, telecommunication systems, water and wastewater treatment facilities, and healthcare facilities, among others.

CUNY sent a survey to the working group to determine the critical infrastructure facility types to focus on in the analysis. The potential sites included gas stations, nursing homes, hospitals, water treatment facilities, shelters, and stores selling emergency supplies. Site selection was based on the following factors:

- Evacuation zones and close proximity to flood plain

- Prone to outages

- No existing backup generation

- Non-hospital site that serves medical needs

- Roof age (20+ years of usable life remaining) with limited shading

- Space for PV and battery (20,000 sq. ft. for solar)

- Number of people the shelters supported during storms Irene and Sandy

- Support from the building staff

- Sites with high demand charges

- Sites where energy efficiency upgrades are being implemented or considered.

The three critical infrastructure facility types selected were fire stations, cooling centers, and coastal storm shelters. CUNY reached out to the New York Department of Citywide Administrative Services (DCAS), New York City Department of Education (NYC- DOE), New York City Fire Department (FDNY), and New York City Housing Authority (NYCHA) to help select the specific sites to be analyzed in the study. The sites selected were:

- NYC-DOE coastal storm shelter: Susan Wagner High School, 1200 Manor Road, Staten Island, New York, 10314

- FDNY fire station: Engine Company 309, 1864 East $48^{\text {th }}$ Street, Brooklyn, New York, 11234

- NYCHA cooling center: Brownsville Senior Center, 528 Mother Gaston Blvd, Brooklyn, New York. 


\subsection{Site Overview}

A summary of the three critical infrastructure sites is presented in this section.

\subsubsection{NYC-DOE High School/Shelter}

\section{Description and Load Data}

The Susan Wagner High School is located on Staten Island and served as a shelter (Figure 1) after Hurricane Sandy with approximately 1,000 beds in the cafeteria. The school lost power after Sandy and had diesel generators brought in for backup power.

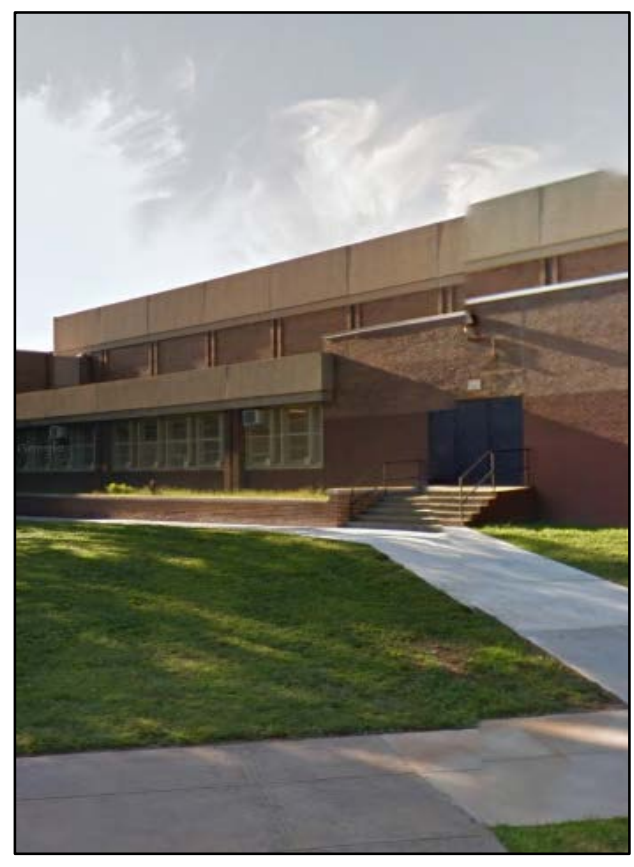

\begin{tabular}{|c|c|c|c|c|}
\hline \multicolumn{5}{|c|}{ Table 1. School Shelter Load Data } \\
\hline Data Source & \multicolumn{4}{|l|}{ DCAS } \\
\hline Data Type & \multicolumn{4}{|c|}{$\begin{array}{l}\text { 15-minute interval; } \\
\text { September } 2014 \text { - August } 2015\end{array}$} \\
\hline Methodology & \multicolumn{4}{|c|}{$\begin{array}{l}\text { Interval data were synthesized by modeling } \\
\text { the building based on DOE's secondary } \\
\text { school commercial reference building and } \\
\text { the New York City climate zone (ASHRAE } \\
\text { climate zone 4A). }\end{array}$} \\
\hline \multirow{2}{*}{ Load Size } & $\begin{array}{l}\text { Minimum } \\
\text { Load }\end{array}$ & $\begin{array}{l}\text { Maximu } \\
m \text { Load }\end{array}$ & $\begin{array}{l}\text { Average } \\
\text { Load }\end{array}$ & $\begin{array}{l}\text { Peak } \\
\text { Loads }\end{array}$ \\
\hline & $42 \mathrm{~kW}$ & $588 \mathrm{~kW}$ & 177 kW & $\begin{array}{l}\text { May - } \\
\text { October }\end{array}$ \\
\hline
\end{tabular}

Figure 1. Susan Wagner High School

Photo by Kari Burman, NREL

The annual energy profile is shown in Figure 2. Relative to May and September, peak loads do not increase during the summer months of June through August due to summer vacation. 


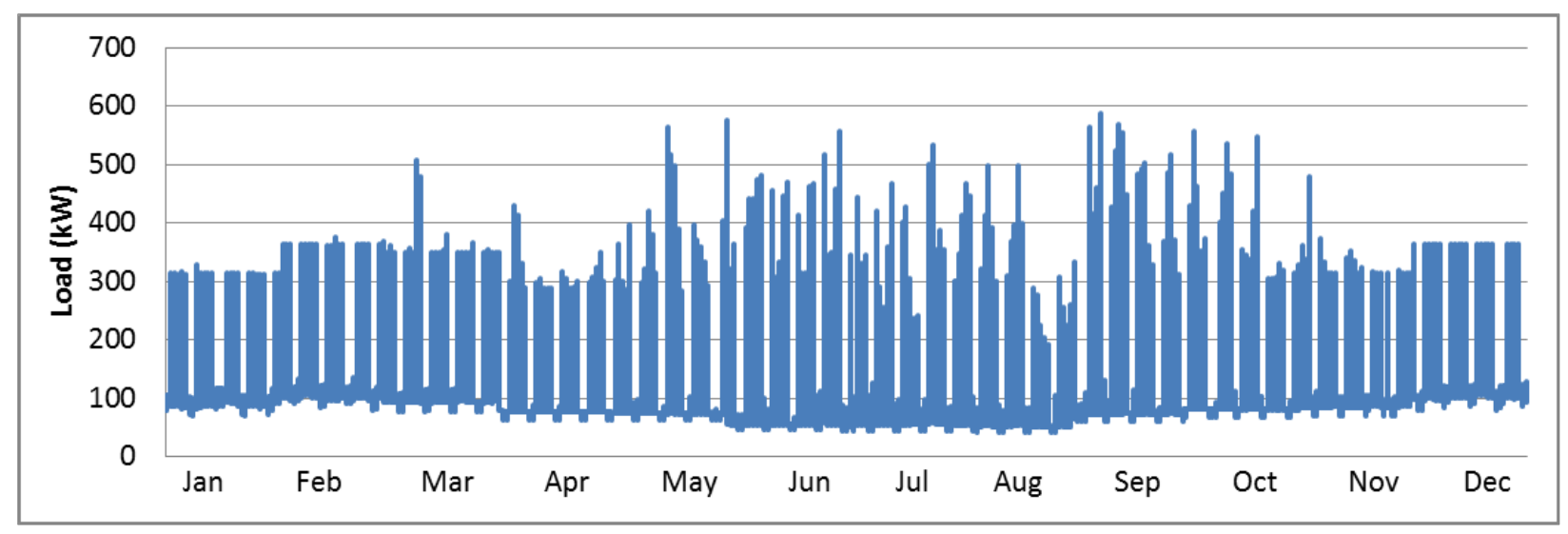

Figure 2. Susan Wagner High School annual energy profile 2014-2015

The composite daily load profile is shown in Figure 3. The peak load occurs during the midafternoon which would be expected for a school.

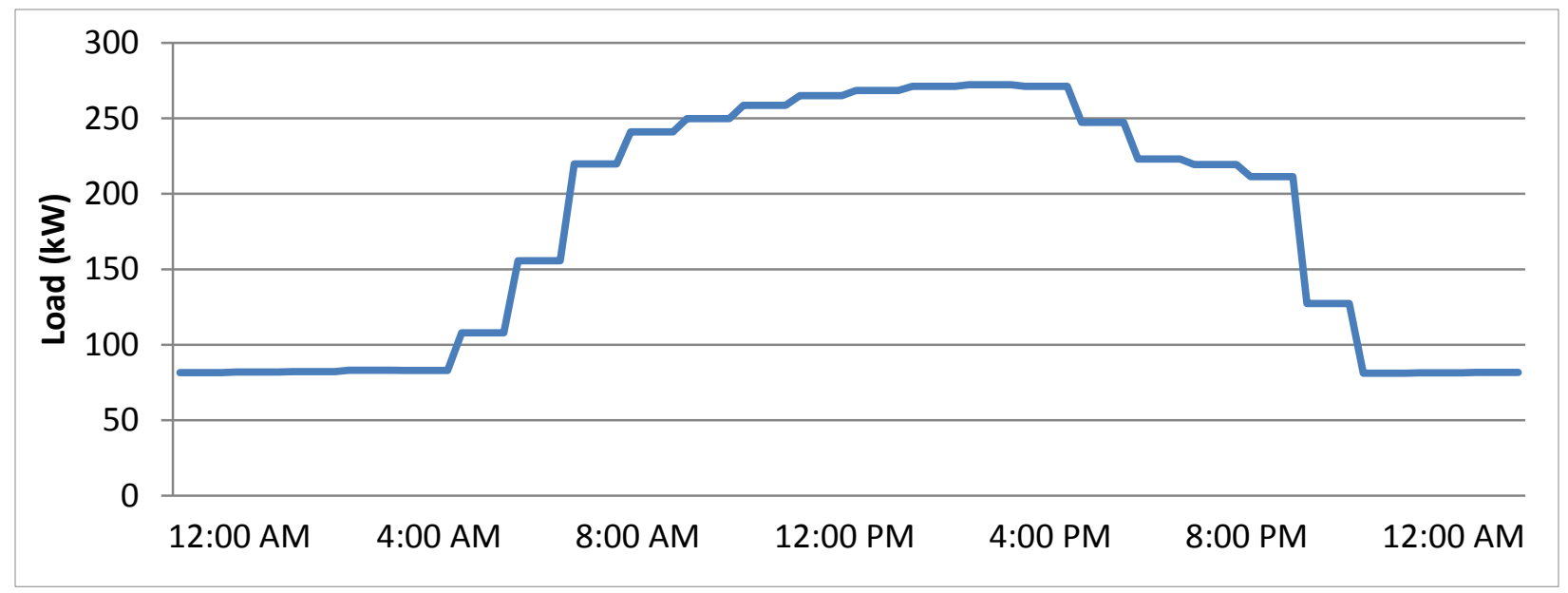

Figure 3. Susan Wagner High School composite daily load profile

\section{Utility Rate Structure}

The Susan Wagner High School is on the NYPA Service Tariff No. 100, Service Classification No. 91 for New York City Public Buildings-Schools, conventional, low tension service (see Service Classification No. 91, Appendix B, Table of Rates and Service). The tariff has an energy charge component (with different charges for summer and winter seasons) and a demand charge component. The demand component is split into a production charge and a delivery charge. For the production charge component, if metered demand in any given month is less than $75 \%$ of the maximum demand in the prior 12 months, billed demand is equal to $75 \%$ of the earlier maximum demand. For the delivery charge component, if metered demand in any given month is less than $39 \%$ of the maximum demand in the prior 18 months, billed demand is equal to $39 \%$ of the earlier maximum demand. Otherwise, the demand charges are the actual measured demand for the month. 
The school is eligible for a net metering agreement. Since this site is on a spot network, however, additional smart grid equipment must be installed at NYC-DOE's expense if the PV system exports to the grid. Per Con Edison guidance, buildings on a spot network may either enable a reverse power relay (RPR) to prevent export at a cost of $\$ 5,000$ or implement a smart grid solution that allows export at a cost of $\$ 50,000-100,000$. If the school installed the maximum PV system size $(210 \mathrm{~kW})$, the energy exported from the system would be worth about $\$ 500 /$ year ( $\$ 12,500$ over 25 years), which is less than the cost of the smart grid solution and negates the benefit of net metering. Therefore, in this analysis we assumed an RPR would be implemented at a cost of $\$ 5,000$ to prevent export.

\section{Critical Load Data}

NYC-DOE provided a list of equipment that would need to operate during an outage as well as an estimate of the number of hours each item would run. Since the shelter might need to operate year-round, we synthesized critical load profiles for summer, winter, and shoulder seasons (see Figures 4-6). The seasonal differences are primarily a result of air conditioning and auxiliary space heating loads. The summer (June-August) critical load includes air conditioning in limited rooms for shelter residents with special needs, while the winter (October-April) critical load includes space heating. The critical load in the shoulder season (September, May) includes neither. We estimated the total critical energy use was $352 \mathrm{kWh} /$ day in the summer and 432 $\mathrm{kWh} /$ day in the winter, which is approximately $7-13 \%$ of typical load. Peak critical demand ranges from $33 \mathrm{~kW}$ in the winter and shoulder seasons to $36 \mathrm{~kW}$ in summer. See Appendix A for a full list of equipment and calculations.

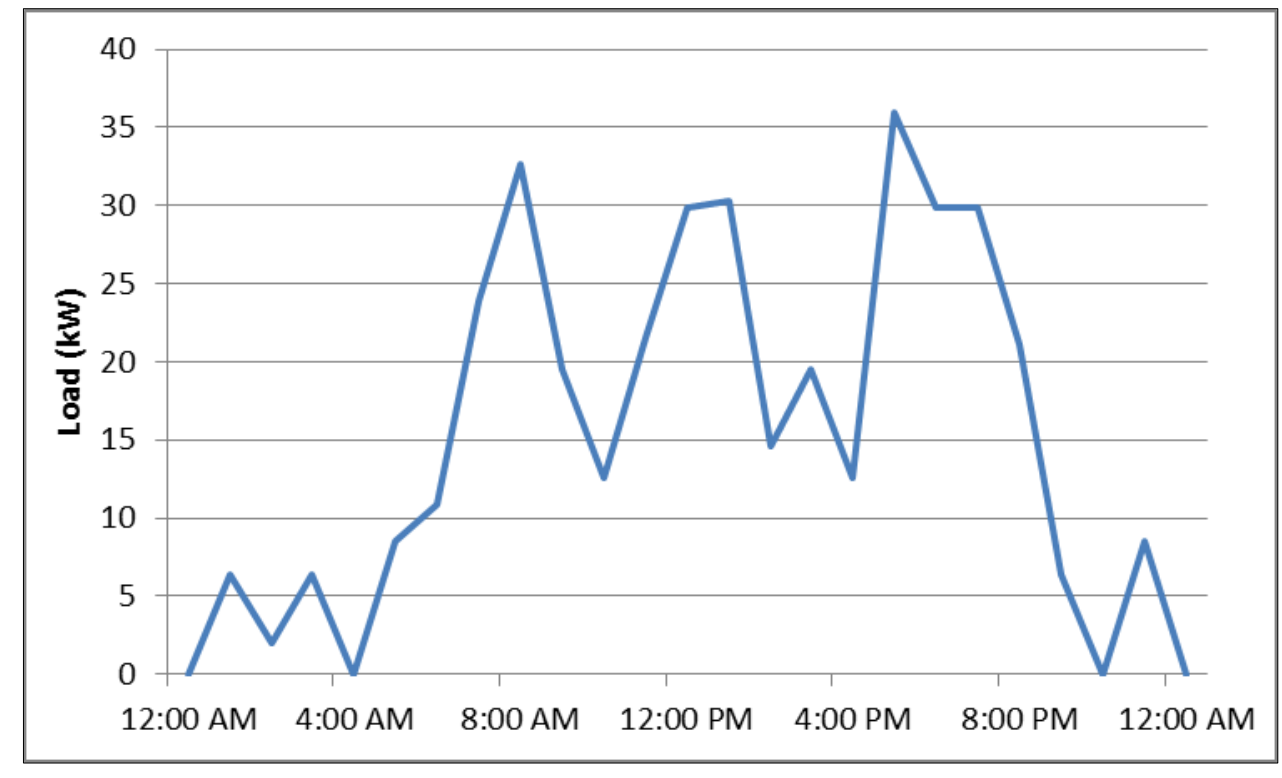

Figure 4. Critical load: summer daily profile 


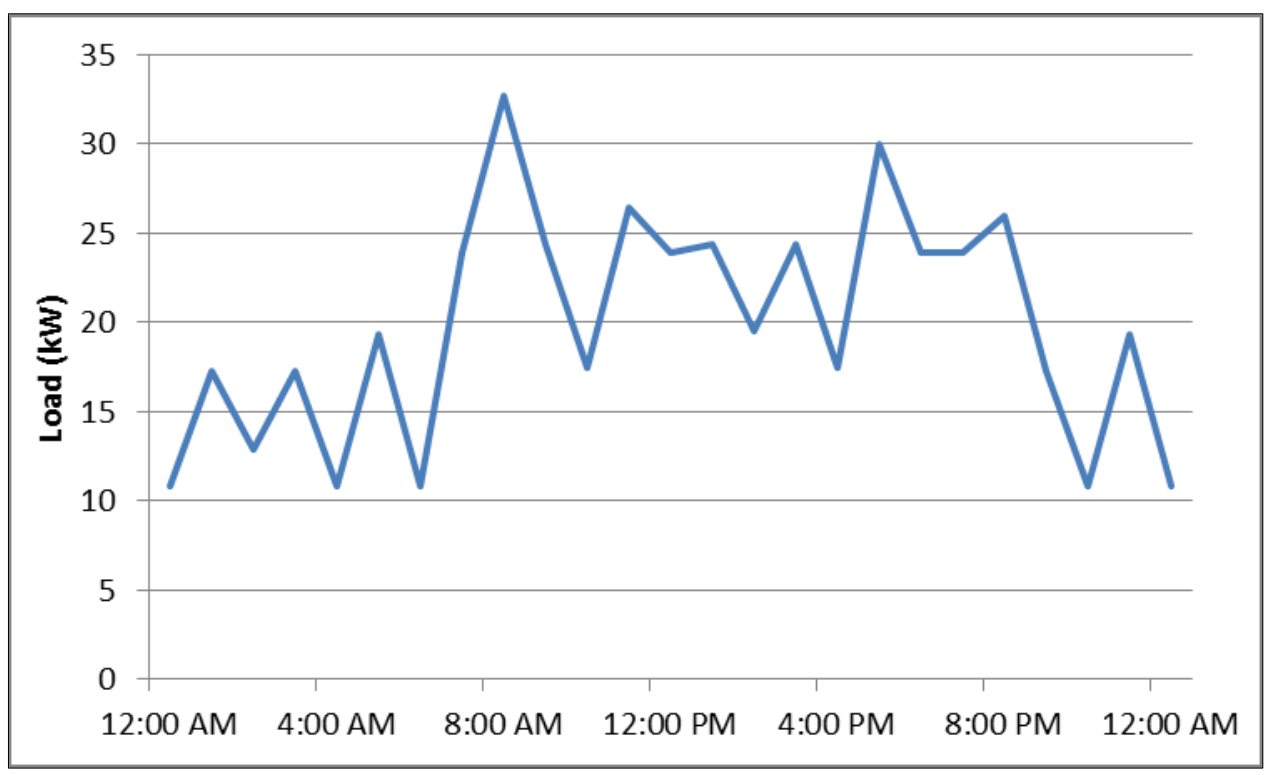

Figure 5. Critical load: winter daily profile

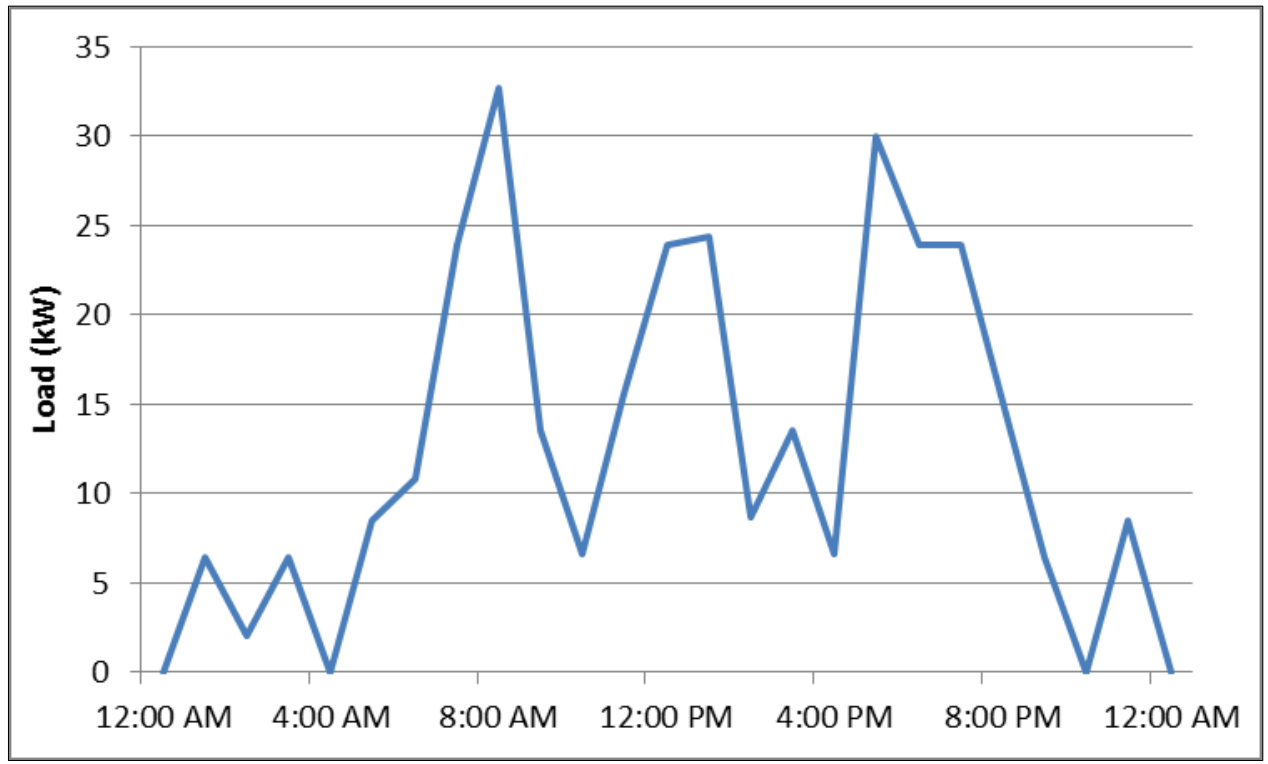

Figure 6. Critical load: shoulder season daily profile

\section{Types of Existing Backup Power}

There is no existing backup power/generation at the Susan Wagner High School. Backup diesel generators were brought in during the power outage after Hurricane Sandy.

\section{PV Assessment}

We visually inspected the roof areas of the high school to measure roof size, presence of rooftop equipment, and potential shading. The high school could accommodate PV systems on the roof areas designated in Figure 7. PV could also potentially be placed on carports in the parking lot, but this area was not considered in this analysis. 


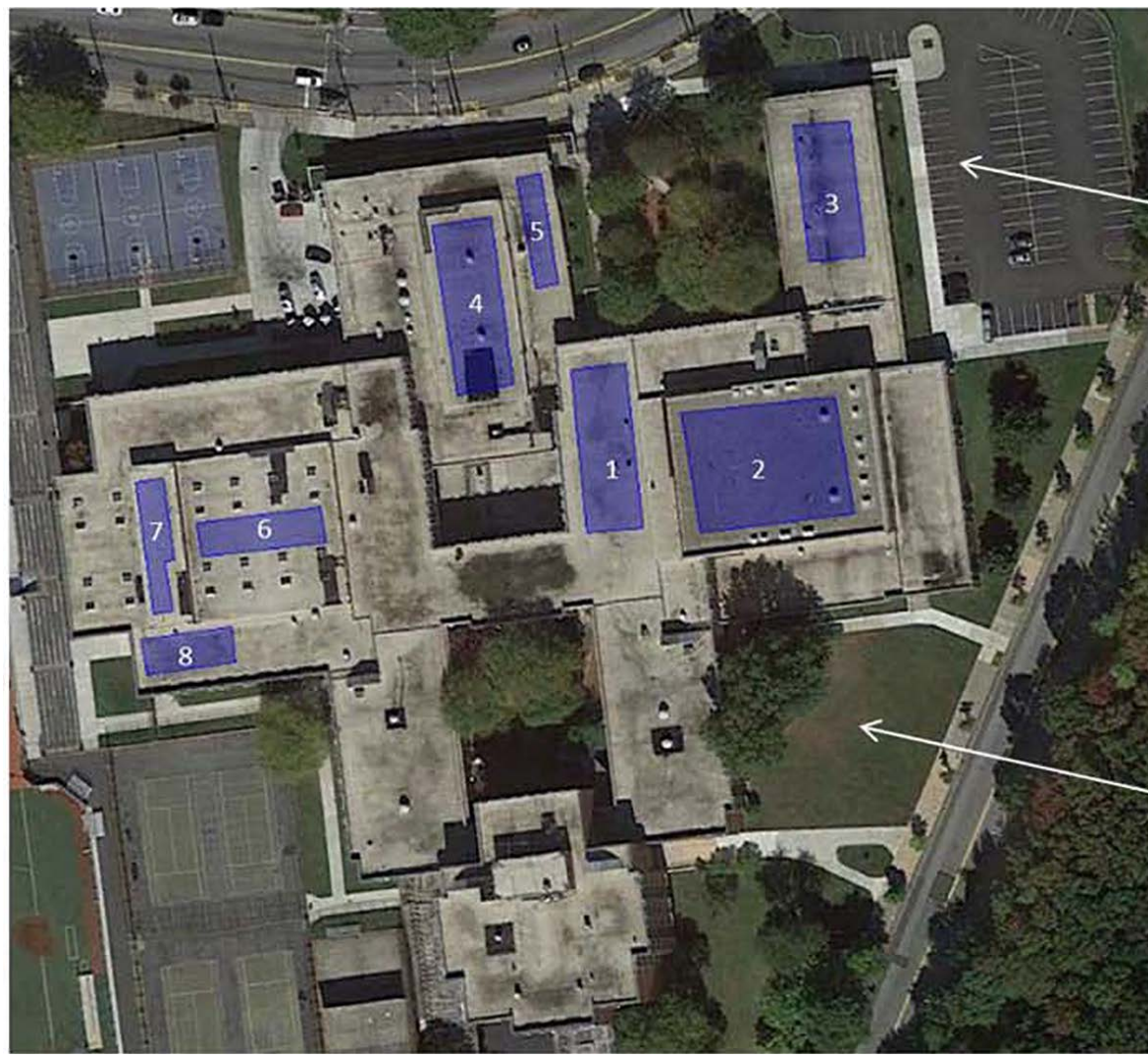

Potential

PV

Carport

New

Building

Figure 7. Susan Wagner High School/Shelter PV layout

Source: () 2016 Google Earth, alterations by Kari Burman

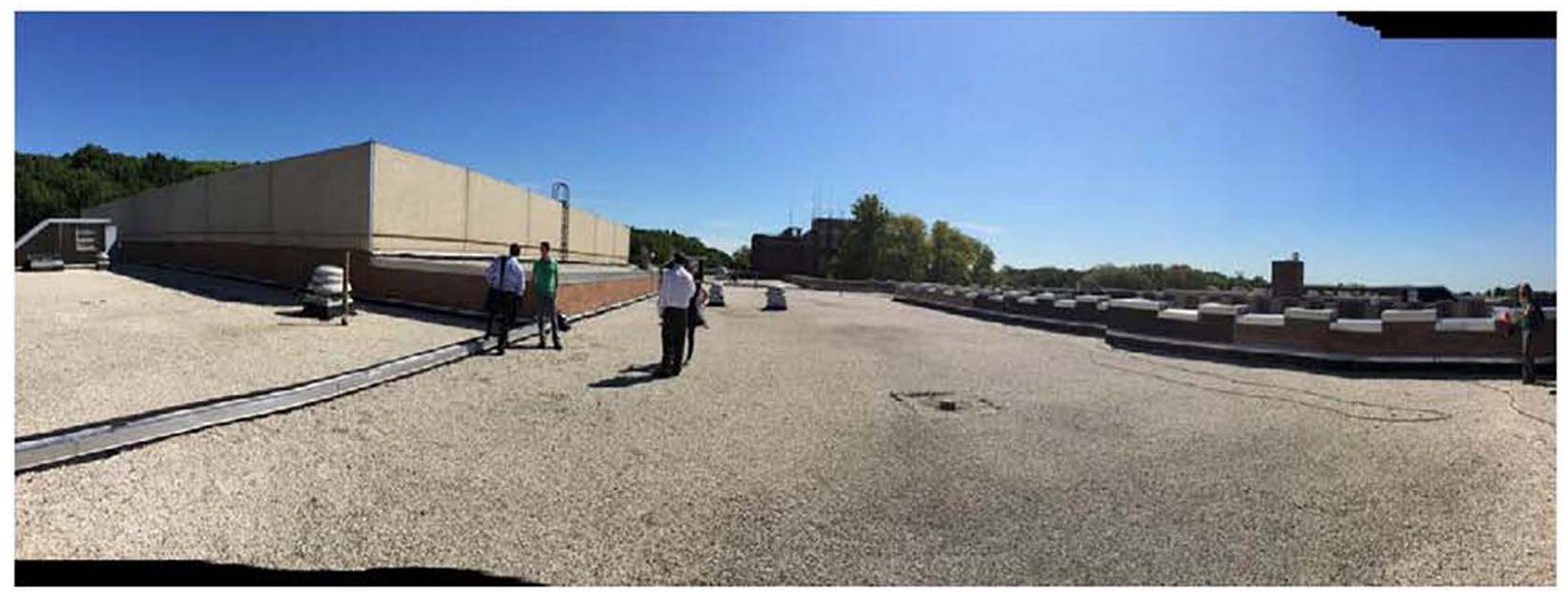

Figure 8. Roof of the Susan Wagner High School, looking south in Area 1

Photo by Kari Burman, NREL 
Table 2. DOE Roof Areas Identified for PV and Associated Details

\begin{tabular}{|c|c|}
\hline Array location and areas $\left(\mathrm{ft}^{2}\right)$ & $\begin{array}{l}\text { Area 1: } 3,626 \mathrm{ft}^{2} \\
\text { Area 2: } 7,373 \mathrm{ft}^{2} \\
\text { Area 3: } 3,000 \mathrm{ft}^{2} \\
\text { Area 4: } 3,960 \mathrm{ft}^{2} \\
\text { Area 5: } 1,050 \mathrm{ft}^{2} \\
\text { Area 6: } 1,722 \mathrm{ft}^{2} \\
\text { Area 7: } 1,320 \mathrm{ft}^{2} \\
\text { Area 8: } 1,272 \mathrm{ft}^{2}\end{array}$ \\
\hline Available roof area $\left(\mathrm{ft}^{2}\right)$ & $23,323 \mathrm{ft}^{2}$ \\
\hline $\begin{array}{l}\text { Maximum PV rated capacity (kW } \\
\text { DC) excluding potential carport } \\
\text { areas }\end{array}$ & $\begin{array}{l}210 \mathrm{~kW}(254,457 \mathrm{kWh} / \mathrm{year} \text {, or } 16 \% \text { of } \\
\text { annual building energy consumption) })^{19}\end{array}$ \\
\hline PV tilt angle & $10^{\circ}$ \\
\hline Roof fall-line azimuth & $173^{\circ}$ \\
\hline Roof type & Flat \\
\hline Roof condition & Fair \\
\hline Roof installation date & New roof will be installed in FY16 \\
\hline Potential obstructions & $\begin{array}{l}\text { Potential PV is designed around large } \\
\text { equipment }\end{array}$ \\
\hline Parapet wall height & 3 feet \\
\hline Solar availability (\%) & $\begin{array}{l}\text { PV was designated for areas with at } \\
\text { least } 90 \% \text { solar availability }\end{array}$ \\
\hline
\end{tabular}

\subsubsection{FDNY Engine Company 309}

\section{Description and Load Data}

Engine Company (EC) 309, located at 1864 East $48^{\text {th }}$ Street in Brooklyn, provides fire and emergency medical services. This facility lost power for about five days after Hurricane Sandy.

Recent renovations at the fire station included a new roof; it re-opened in July 2015. Because the building systems and the occupancy of the station changed, historical pre-renovation energy data for EC309 were not representative of future energy consumption. We used the one month of post-renovation energy data available (August 2015) and estimated the remaining months of the year based on energy data for EC315, a station of similar size and with similar August energy consumption and demand.

\footnotetext{
${ }^{19}$ A 210-kW PV system would generate 254,457 kWh/year (estimated using PVWatts). The school's annual energy consumption is $1,556,800 \mathrm{kWh}$.
} 


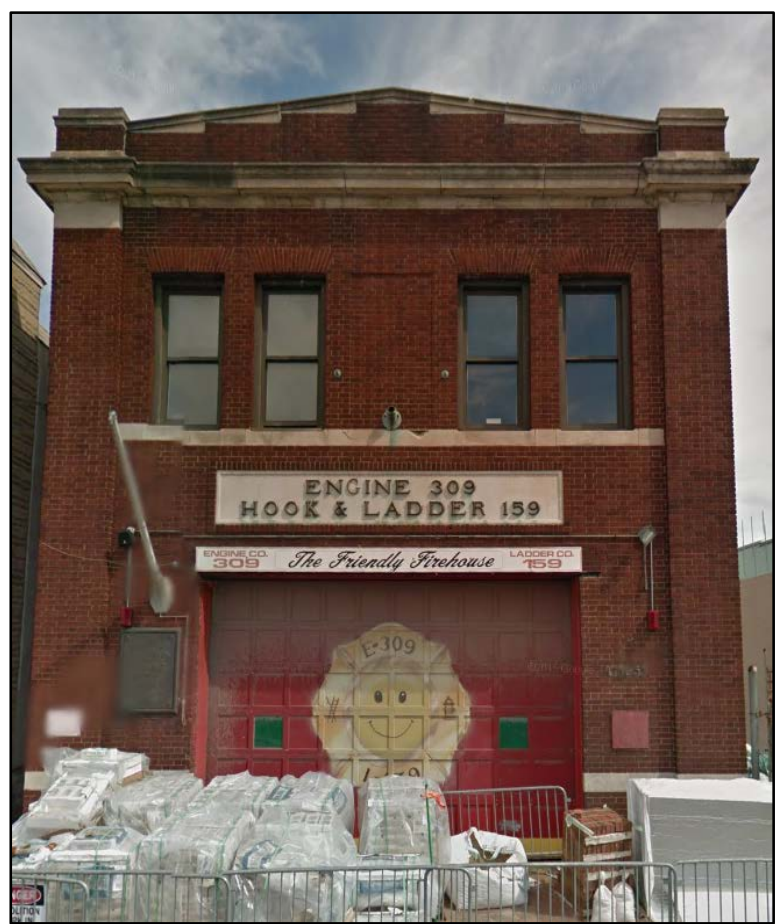

\begin{tabular}{|c|c|c|c|c|}
\hline Data Source & \multicolumn{4}{|l|}{ DCAS } \\
\hline Data Type & \multicolumn{4}{|c|}{ Energy and demand data } \\
\hline Methodology & \multicolumn{4}{|c|}{$\begin{array}{l}\text { Interval data were not available for this site, } \\
\text { so they were estimated from the monthly } \\
\text { electric use of a similar station by modeling } \\
\text { the building based on DOE's commercial } \\
\text { reference buildings and the New York City } \\
\text { climate zone (ASHRAE climate zone 4A). A } \\
\text { fire station is not one of the DOE commercial } \\
\text { reference building types, so we assumed } \\
50 \% \text { warehouse (for the garage area } \\
\text { downstairs) and } 50 \% \text { midrise apartment (for } \\
\text { the upstairs firefighter living quarters). }\end{array}$} \\
\hline \multirow[b]{2}{*}{ Load Size } & $\begin{array}{l}\text { Minimum } \\
\text { Load }\end{array}$ & $\begin{array}{l}\text { Maximum } \\
\text { Load }\end{array}$ & $\begin{array}{l}\text { Average } \\
\text { Load }\end{array}$ & $\begin{array}{l}\text { Peak } \\
\text { Loads }\end{array}$ \\
\hline & 2.86 kW & $63.2 \mathrm{~kW}$ & $15.2 \mathrm{~kW}$ & $\begin{array}{l}\text { May - } \\
\text { October }\end{array}$ \\
\hline
\end{tabular}

Figure 9. FDNY EC309 in Marine Park

Photo by Kari Burman, NREL

The annual electricity profile is shown in Figure 10.

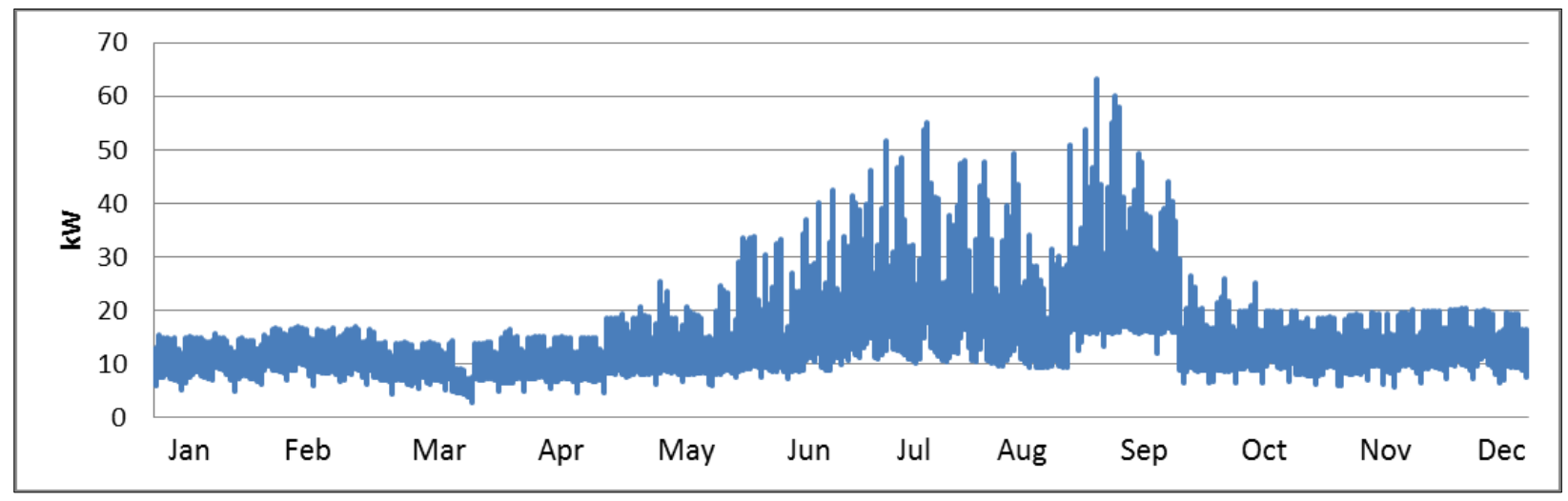

Figure 10. FDNY EC309 annual electricity profile 
Peak loads occur during the hotter summer months of July-September. The composite daily load profile is shown in Figure 11. The daily peak load occurs around 4 p.m.

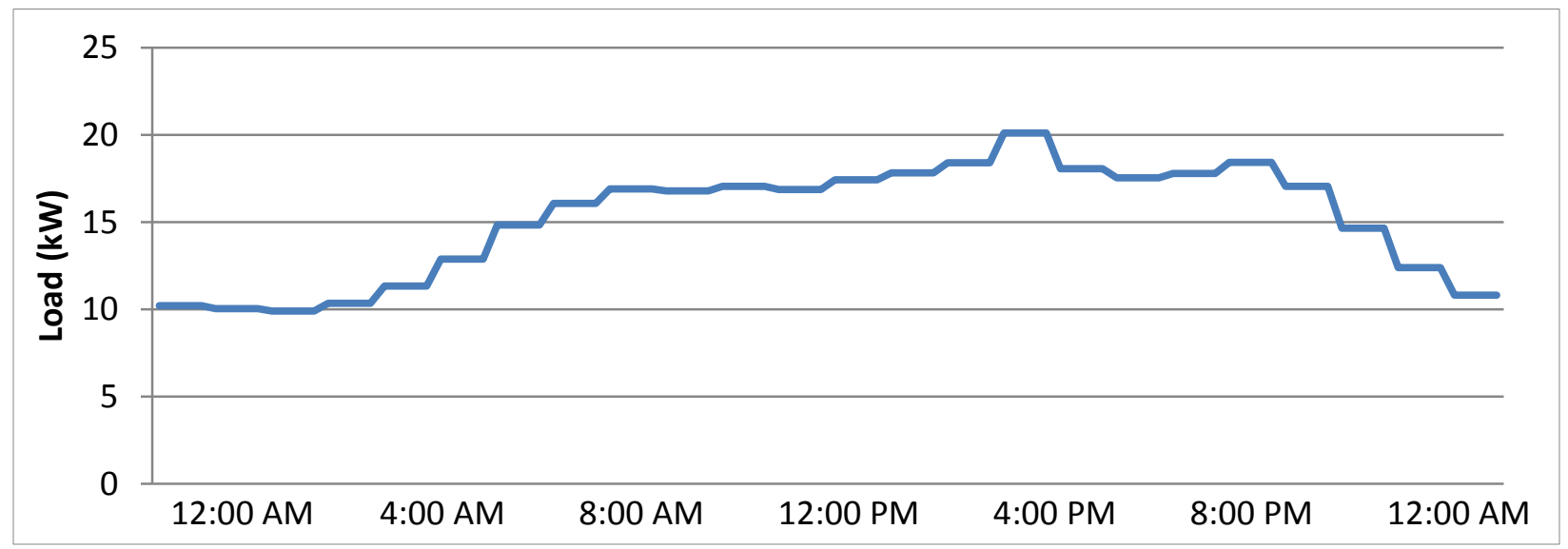

Figure 11. FDNY EC309 composite daily load profile

\section{Utility Rate Structure}

The fire station is on the NYPA Service Tariff No. $100^{20}$, Service Classification No. 91 for New York City Public Buildings, conventional, low tension service (see Service Classification No. 91, Appendix B, Table of Rates and Services). The tariff has an energy charge component (with different charges for summer and winter seasons) and a demand charge component. The demand component is split into a production charge and a delivery charge. For the production charge component, if metered demand in any given month is less than $75 \%$ of the maximum demand in the prior 12 months, billed demand is equal to $75 \%$ of the earlier maximum demand. For the delivery charge component, if metered demand in any given month is less than $39 \%$ of the maximum demand in the prior 18 months, billed demand is equal to $39 \%$ of the earlier maximum demand. Otherwise, the demand charges are the actual recorded value for the month.

The fire station is eligible for a net metering agreement. This building is on a radial grid.

\section{Critical Load Data}

FDNY did not provide a specific list of critical loads, so we estimated the critical load by applying a percentage reduction to the typical load. . The critical load level assumed for the fire station is $65 \%$ of typical load ${ }^{21}$, which is approximately $350 \mathrm{kWh} /$ day in the summer and 170 $\mathrm{kWh} /$ day in the winter. This would include loads such as computers and communication equipment in the control center, lighting, and pumps to fuel trucks. The critical annual load profile is shown in Figure 12.

\footnotetext{
${ }^{20}$ NYPA. 2015. Electric Service Tariff for New York City Governmental Customers, Service Tariff No. 100, Date of Issue March 2015.

${ }^{21}$ The NYC and San Francisco Solar Market Pathways teams conducted site visits at fire stations to determine critical loads. Critical loads were estimated by staff to be in the range of $65-100 \%$; $65 \%$ was selected since backing up a larger load would likely be cost prohibitive.
} 


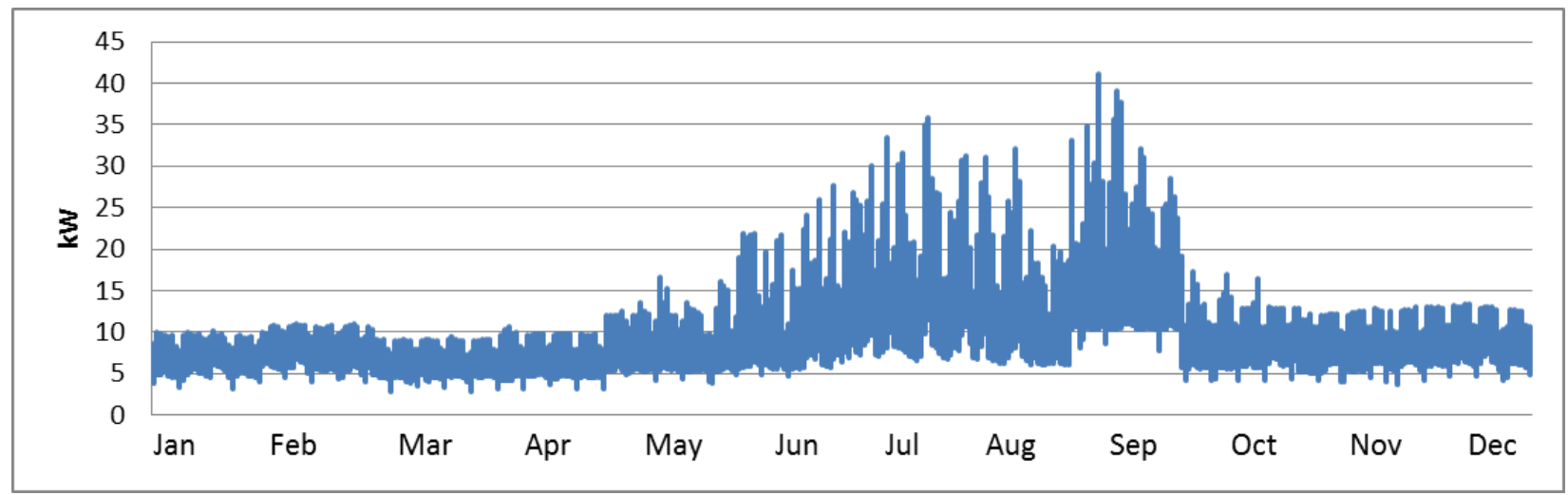

Figure 12. Annual critical load profile

\section{Types of Existing Backup Power}

There is no existing backup power/generation at this fire station at the time of the site visit.

\section{PV Assessment}

We visually inspected the roof areas of the fire station to measure roof size and identify the presence of rooftop equipment and potential shading. For buildings under 100 linear feet high, the New York City fire code ${ }^{22}$ requires a clear path on the roof of not less than six feet horizontal width from the front of the building to the rear of the building. An aerial view of the roof, with space available for PV, is shown in Figure 13 and a picture of the roof is shown in Figure 14. Table 4 shows the roof dimensions and PV capacity. This roof is estimated to be able to support approximately $10.2 \mathrm{~kW}-\mathrm{DC}$ of PV.

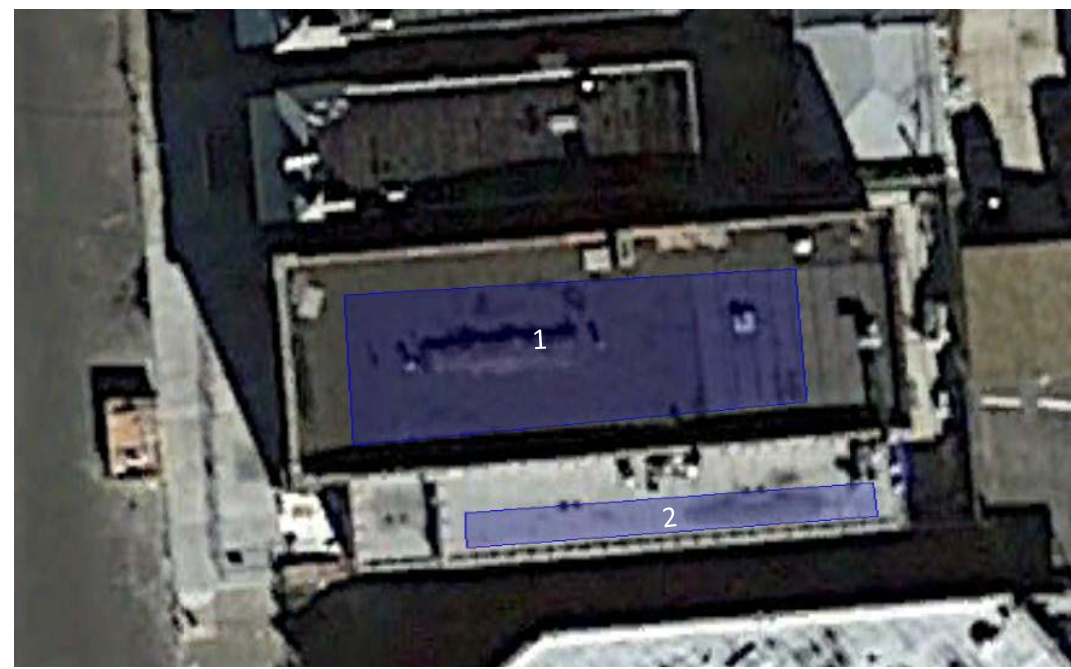

Figure 13. FDNY: EC309 PV layout

Source: @ 2016 Google Earth, alterations by Kari Burman

22 The New York City Fire Code, Chapter 504 and 512. 2014.

http://www.nyc.gov/html/fdny/apps/pdf_viewer/viewer.html?file=firecode_chap_05.pdf\&section=firecode_2014. 


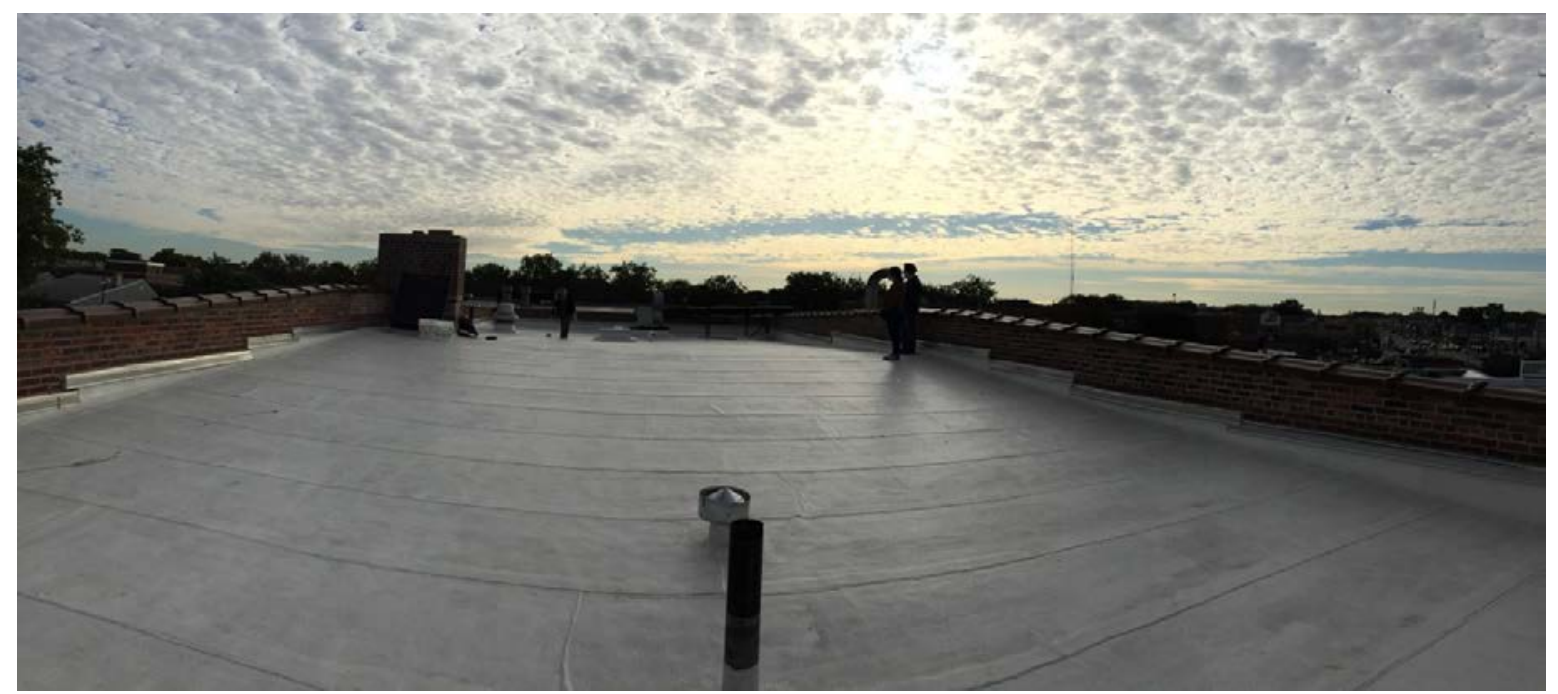

Figure 14. Roof of the fire station looking east from the west side Photo by Allison Silverman, CUNY

Table 4. FDNY Roof Areas Identified for PV and Associated Details

\begin{tabular}{|c|c|}
\hline \multirow[t]{2}{*}{ Array location and areas $\left(\mathrm{ft}^{2}\right)$} & Area 1: $891.3 \mathrm{ft}^{2}$ \\
\hline & Area 2: $251.6 \mathrm{ft}^{2}$ \\
\hline Available roof area $\left(\mathrm{ft}^{2}\right)$ & $1,142 \mathrm{ft}^{2}$ \\
\hline Maximum PV rated capacity (kW DC) & $\begin{array}{l}10.2 \mathrm{~kW}(12,362 \mathrm{kWh} / \mathrm{year} \text {, or } 9.2 \% \text { of building annual } \\
\text { energy consumption })^{23}\end{array}$ \\
\hline PV tilt angle & $10^{\circ}$ \\
\hline Roof fall-line azimuth & $175^{\circ}$ \\
\hline Roof type & Flat \\
\hline Roof condition & New \\
\hline Roof installation date & 2015 \\
\hline Potential obstructions & $\begin{array}{l}\text { Large equipment that was previously on the roof (shown in } \\
\text { the roof image above) was removed during the renovation }\end{array}$ \\
\hline Parapet wall height & 3 feet \\
\hline Solar availability (\%) & $95 \%$ \\
\hline
\end{tabular}

${ }^{23}$ A 10.2-kW PV system would generate 12,362 kWh/year (estimated using PVWatts). The fire station's annual energy consumption is $133,812 \mathrm{kWh}$. 


\subsubsection{NYCHA Cooling Center}

\section{Description and Load Data}

The Brownsville Senior Center (Figure 15) is located at 528 Mother Gaston Blvd in Brooklyn, New York. The senior center is located on the first floor of a seven story apartment building and may serve as a cooling center for up to 70 people during heat waves. The building lost power for about three days after Hurricane Sandy.

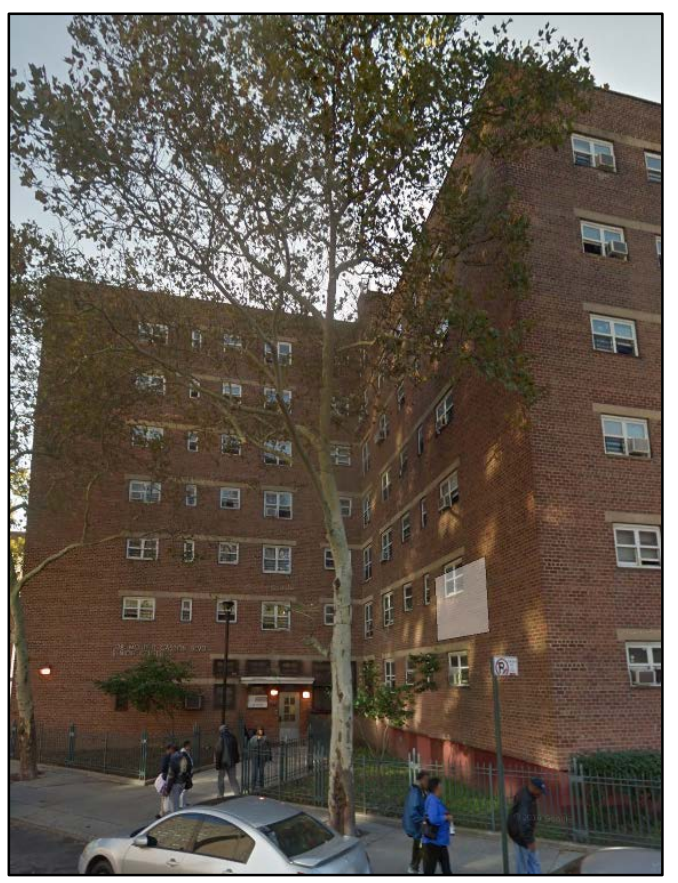

\begin{tabular}{|c|c|c|c|c|}
\hline Data Source & \multicolumn{4}{|l|}{ NYCHA } \\
\hline Data Type & \multicolumn{4}{|c|}{$\begin{array}{l}\text { 15-minute interval; } \\
\text { January } 2015 \text { - September } 2015\end{array}$} \\
\hline Methodology & \multicolumn{4}{|c|}{$\begin{array}{l}\text { 15-minute interval data were provided for } \\
\text { January-September. October - December } \\
\text { data were estimated based on previous } \\
\text { months: March for October, February for } \\
\text { November and January for December. }\end{array}$} \\
\hline \multirow[b]{2}{*}{ Load Size } & $\begin{array}{l}\text { Minimum } \\
\text { Load }\end{array}$ & $\begin{array}{l}\text { Maximum } \\
\text { Load }\end{array}$ & $\begin{array}{l}\text { Average } \\
\text { Load }\end{array}$ & $\begin{array}{l}\text { Peak } \\
\text { Loads }\end{array}$ \\
\hline & $21.5 \mathrm{~kW}$ & $77.3 \mathrm{~kW}$ & $30.5 \mathrm{~kW}$ & $\begin{array}{l}\text { June - } \\
\text { Sept. }\end{array}$ \\
\hline
\end{tabular}

Figure 15. NYCHA Brownsville Senior Center

Photo by Allison Silverman, CUNY 


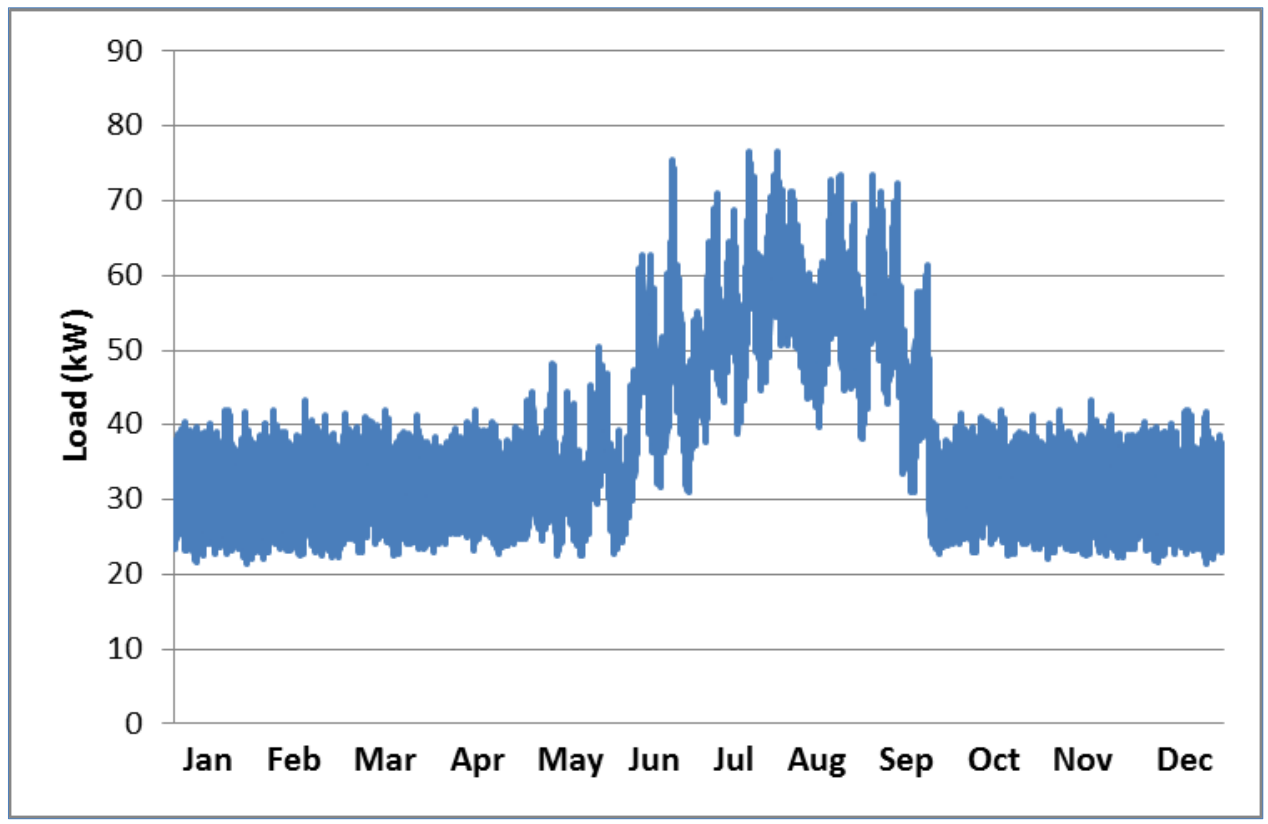

Figure 16. NYCHA Brownsville Senior Center annual load profile

A composite daily load profile for the entire apartment building was created by averaging the daily load profiles for the entire year (Figure 16 and Figure 17). The peak load occurs in the evening between 8 p.m. - 11 p.m., and the minimum load occurs in the morning between the hours of 5 a.m. - 9 a.m.

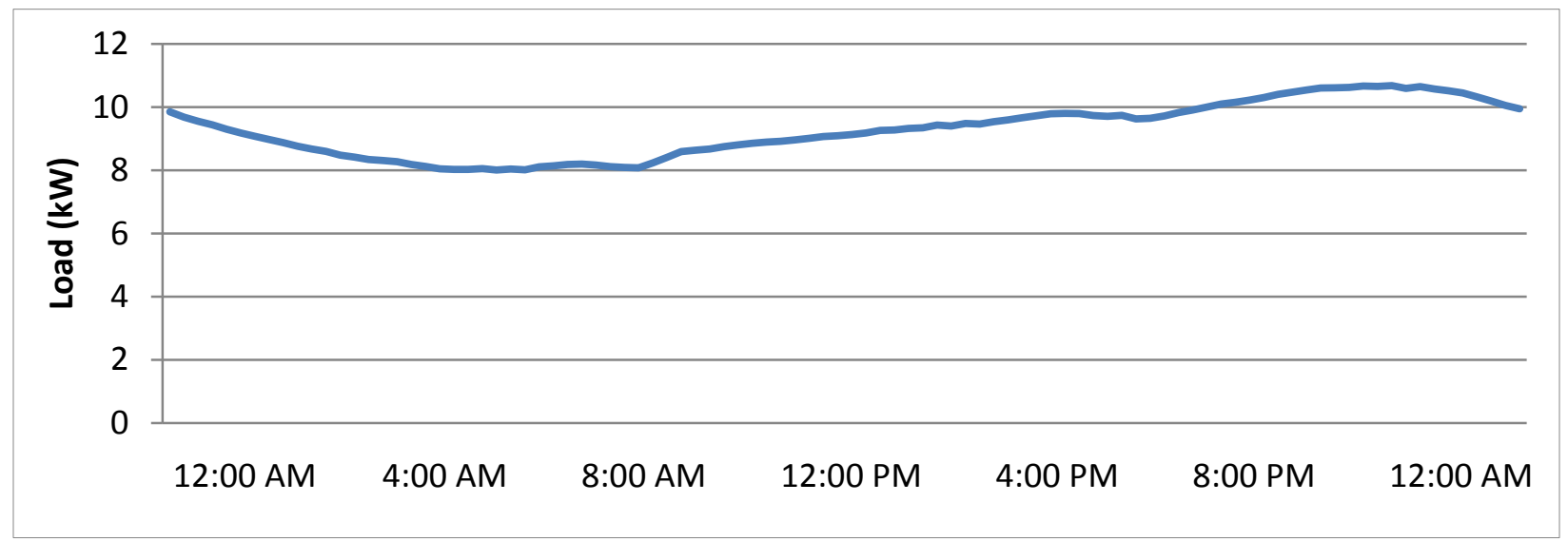

Figure 17. NYCHA annual composite daily load profile

\section{Utility Rate Structure}

The NYCHA Brownsville Senior Center is on the NYPA Service Tariff No. 100, Service Classification No. 68 for Multiple Dwellings-Redistribution, Time of Day (TOD), low tension service (see Service Classification No. 68, Appendix B, Table of Rates and Service). The tariff has an energy charge component (with different charges for summer and winter seasons) and on and off peak periods. It also has a demand charge component with different demand charges for summer and winter periods. The demand component is split into a production charge and a delivery charge. For the production charge component, if metered demand in any given month is 
less than $75 \%$ of the maximum demand in the prior 12 months, billed demand is equal to $75 \%$ of the earlier maximum demand. For the delivery charge component, if metered demand in any given month is less than $39 \%$ of the maximum demand in the prior 18 months, billed demand is equal to $39 \%$ of the earlier maximum demand. Otherwise, the demand charges are based on the actual recorded value for the month.

The NYCHA Brownsville Senior Center is eligible for a net metering agreement. This building is on an area network.

\section{Critical Load Data}

The critical load profile for the NYCHA cooling center was synthesized by adding the individual component loads as specified by Brownsville staff. These components consist of air conditioners, a computer, lighting, fire alarm system, and refrigerator. The air conditioners are estimated to operate 8 hours/day during the grid outage and represent the majority of energy consumption in the critical load ( $\sim 96 \mathrm{kWh} /$ day). See Appendix A for a full list of critical loads and calculations. A graph of the synthesized critical daily load profile used in this analysis is shown in Figure 18. Since the cooling center would only operate during the summer, the critical load profile was developed for the summer season only.

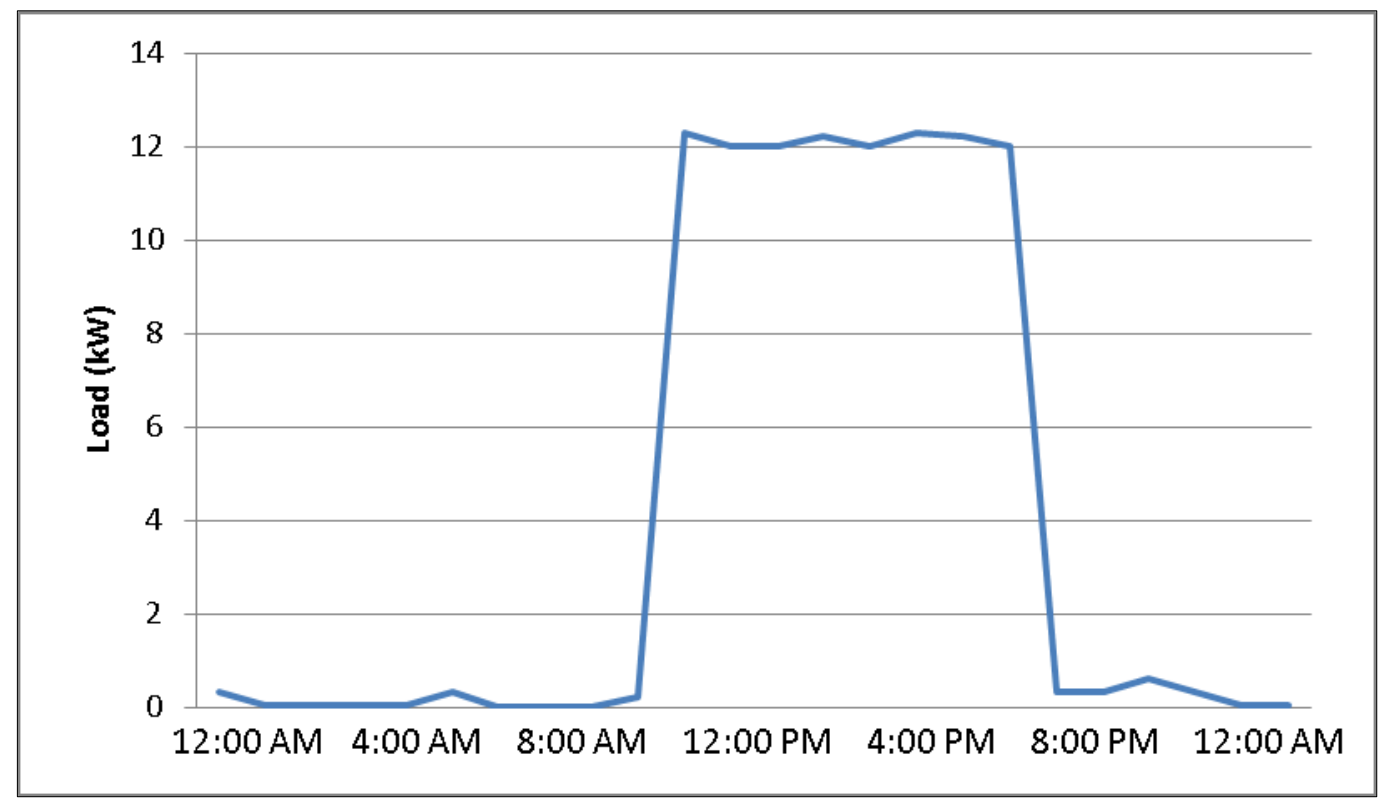

Figure 18. NYCHA Brownsville Senior Center daily critical load profile

\section{Types of Existing Backup Power}

There is no existing backup power at Brownsville Senior Center.

\section{PV Assessment}

We visually inspected the roof areas of the NYCHA Senior Center to measure roof size, presence of rooftop equipment, and potential shading. The Senior Center could accommodate PV systems on the roof areas designated in the figures below. Note that areas on the $6^{\text {th }}$ floor were not 
considered for PV due to shading from the $7^{\text {th }}$ floor and elevator shaft in the center. This building is under 100 linear feet, so it must comply with the New York City fire code ${ }^{24}$ which requires a clear path on the roof of not less than six feet horizontal width from the front of the building to the rear of the building. An aerial view of the roof with space available for PV is shown in Figure 19, and a picture of the roof is shown in Figure 20. Table 6 shows the roof dimensions and PV capacity. This roof can support approximately $9.2 \mathrm{~kW}-\mathrm{DC}$ of PV.

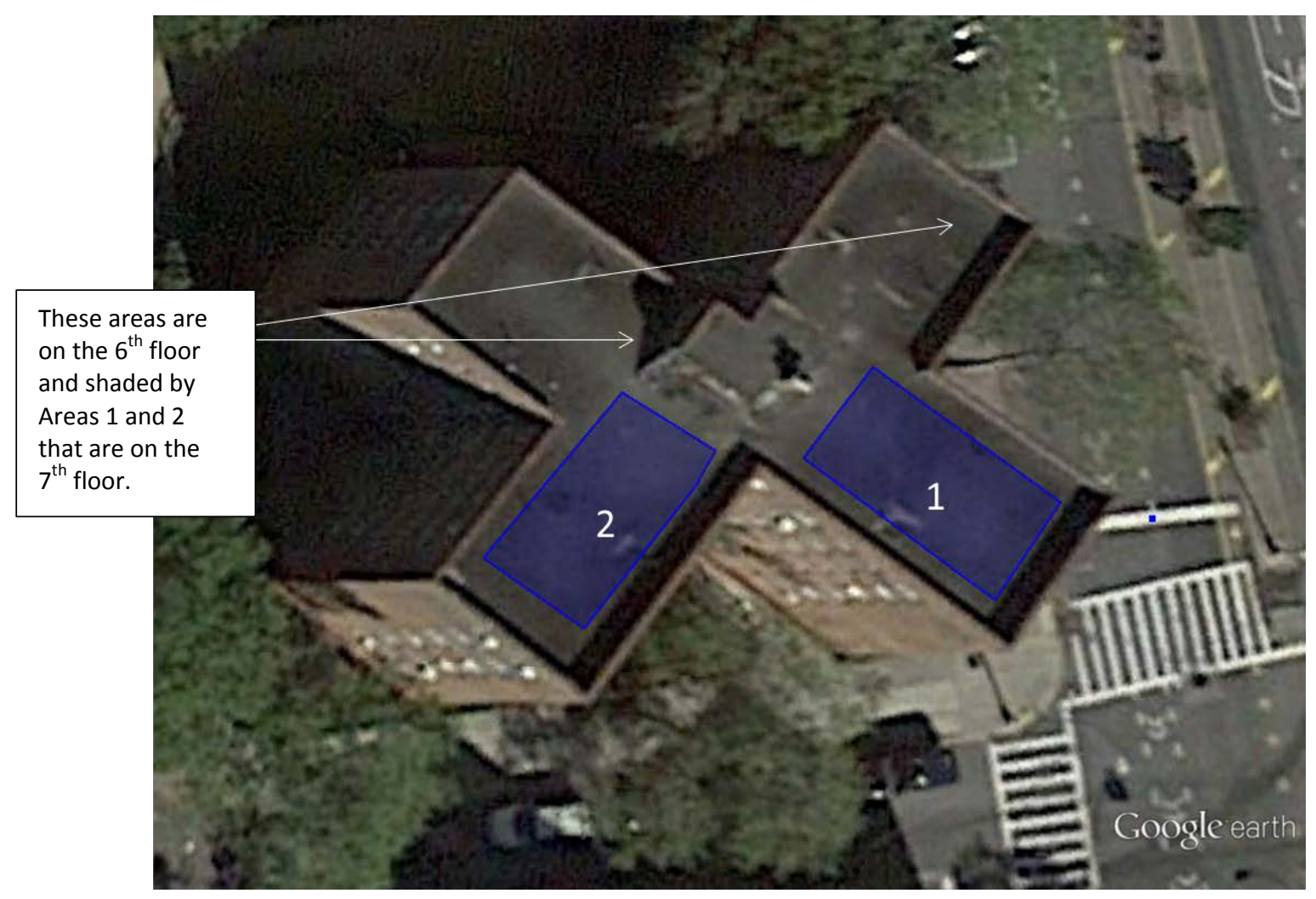

Figure 19. NYCHA Senior Center PV layout

Source: ( 2016 Google Earth, alterations by Kari Burman

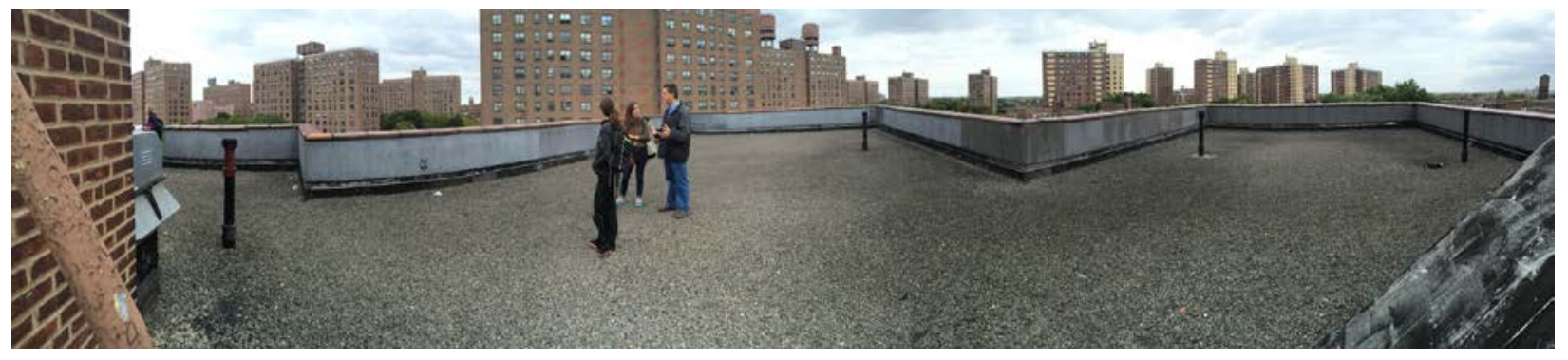

Figure 20. Roof of the NYCHA Senior Center/Cooling Center looking south

Photo by Allison Silverman, CUNY

\footnotetext{
${ }^{24}$ The New York City Fire Code, Chapter 504 and 512. 2014.

http://www.nyc.gov/html/fdny/apps/pdf_viewer/viewer.html?file=firecode_chap_05.pdf\&section=firecode 2014.
} 
Table 6. NYCHA Roof Areas Identified for PV and Associated Details

\begin{tabular}{|c|c|}
\hline \multirow[t]{2}{*}{ Array location and areas $\left(\mathrm{ft}^{2}\right)$} & Area 1: $511 \mathrm{ft}^{2}$ \\
\hline & Area 2: $511 \mathrm{ft}^{2}$ \\
\hline Available roof area $\left(\mathrm{ft}^{2}\right)$ & $1,022 \mathrm{ft}^{2}$ \\
\hline Maximum PV rated capacity (kW DC) & $\begin{array}{l}9.2 \mathrm{~kW}(11,137 \mathrm{kWh} / \mathrm{year} \text {, or } 3.4 \% \text { of annual } \\
\text { energy consumption) }\end{array}$ \\
\hline PV tilt angle & $10^{\circ}$ \\
\hline Roof fall-line azimuth & $\begin{array}{l}\text { Area 1: } 125^{\circ} \\
\text { Area 2: } 212^{\circ}\end{array}$ \\
\hline Roof type & Flat, built up roof \\
\hline Roof condition & Fair \\
\hline Roof installation date & $\begin{array}{l}\text { Brownsville roof replacement is in the Capital Plar } \\
\text { for } 2017 \text { (Design) and } 2018 \text { (Construction) to be } \\
\text { funded from federal capital funds }\end{array}$ \\
\hline Potential obstructions & $\begin{array}{l}\text { No large equipment on the roof areas that are } \\
\text { proposed for PV }\end{array}$ \\
\hline Parapet wall height & 3 feet \\
\hline Solar availability (\%) & $95 \%$ \\
\hline
\end{tabular}

\subsection{Modeling Description and Assumptions}

REopt is NREL's software modeling platform for energy system integration and optimization. ${ }^{26}$

The core of the model consists of a mixed-integer linear program with minimizing life cycle cost of energy as the objective function. The objective of the model is, therefore, to find the combination of energy assets that can supply electricity to the site at lowest cost, including capital, operating, fuel, and maintenance costs, over the analysis period ( 25 years in this case). For the purposes of this analysis, the model could select from among the utility grid, PV, batteries, or a diesel generator to meet the load, though not all technologies were available in every scenario. Each technology had specific operating constraint, capital cost, and operating cost assumptions which are described in the table below.

REopt is a time-series model that determines the optimal operation of each energy asset during every time step. For this analysis, the model was run with 8,760 one-hour time steps per year. Since the model is formulated as a mixed-integer linear program, it does not need to be programmed with a specific dispatch strategy for the dispatchable assets, but can, instead, find the operating strategy that minimizes overall life cycle cost. This dispatch strategy is one of the model outputs, along with the optimal selection and sizing of the components. Components are

\footnotetext{
${ }^{25}$ A 9.2-kW PV system would generate $11,137 \mathrm{kWh} /$ year (estimated using PVWatts). The building's annual energy consumption is $325,138 \mathrm{kWh}$.

${ }^{26}$ Simpkins, T., D. Cutler, K. Anderson, D. Olis, E. Elgqvist, M. Callahan, and A. Walker. 2014. REopt: A Platform for Energy System Integration and Optimization. NREL/CP-7A40-61783.

http://www.nrel.gov/docs/fy14osti/61783.pdf.
} 
sized using continuous variables rather than discrete variables for sizing, so the exact sizes recommended may not be available in the market. For example, an 11-kW, 32-kWh battery may be recommended, but the closest commercially available size may be a $10-\mathrm{kW}, 30-\mathrm{kWh}$ battery.

The table below summarizes the modeling assumptions used at each site.

Table 7. Assumptions for the Analysis

\begin{tabular}{|c|c|}
\hline \multicolumn{2}{|l|}{ PV Assumptions } \\
\hline PV capital costs & $\begin{array}{l}\text { - NYC-DOE School Shelter: } \$ 3.45 / \mathrm{W}-\mathrm{DC} \text { based on projected third party } \\
\text { financing prices for DCAS } \\
\text { - FDNY Fire Station: } \$ 3.88 / \mathrm{W}-\mathrm{DC} \text { based on DCAS historic PV contract } \\
\text { prices } \\
\text { - NYCHA Cooling Center: } \$ 4.64 / \mathrm{W}-\mathrm{DC} \text { based on } 2015 \text { NYC Solarize } \\
\text { contract pricing for } 10-\mathrm{kW} \text { flat roof systems }\end{array}$ \\
\hline PV cost details & $\begin{array}{l}\text { - Costs are total installed costs including engineering, permitting, and } \\
\text { interconnection. Additional potential costs are listed at the end of this } \\
\text { section. } \\
\text { - Costs include a grid-forming inverter that assists with regulation of both } \\
\text { voltage and frequency during a grid outage. } \\
\text { - A cost of } \$ 5,000 \text { is added to the capital cost of systems at the DOE site } \\
\text { (in addition to the } \$ 3.45 / \mathrm{W} \text { PV capital cost) to pay for an RPR to prevent } \\
\text { export to the spot network. }\end{array}$ \\
\hline O\&M cost & $\$ 20 / \mathrm{kW} /$ year \\
\hline PV system specifications & $\begin{array}{l}\text { - Calculations assume standard modules in a fixed roof mount array with } \\
14 \% \text { system losses. } \\
\text { - Systems are modeled with } 10^{\circ} \text { tilt. } \\
\text { - System azimuth varied by site }\left(180^{\circ} \text { is a due-south orientation): }\right. \\
\text { O NYC-DOE: } 173^{\circ} \\
\text { O FDNY: } 175^{\circ} \\
\text { O NYCHA Area } 1: 125^{\circ} \text {, Area } 2: 212^{\circ} \text {. }\end{array}$ \\
\hline
\end{tabular}




\begin{tabular}{|c|c|}
\hline \multicolumn{2}{|l|}{ Storage Assumptions } \\
\hline Battery type & Lithium-ion nickel manganese cobalt oxide ${ }^{21}$ \\
\hline Minimum state of charge & $20 \%{ }^{28}$ \\
\hline $\begin{array}{l}\text { State of charge at time of } \\
\text { outage }\end{array}$ & $100 \%$ \\
\hline Round-Trip AC-AC Efficiency & $92.5 \%^{29}$ \\
\hline Capital cost & Initial Cost: $\$ 520 / \mathrm{kWh}, \$ 1000 / \mathrm{kW}^{30,31}$ \\
\hline Replacement cost & $\begin{array}{l}\text { Assume battery is replaced once at year 12. Estimated replacement } \\
\text { cost in } 2037 \text { is } \$ 200 / \mathrm{kWh}, \$ 200 / \mathrm{kW}\end{array}$ \\
\hline \multicolumn{2}{|l|}{ Diesel Generator Assumptions } \\
\hline Capital cost & $\$ 1.50 / \mathrm{W}$ \\
\hline Non-fuel O\&M cost & $\$ 0.02 / \mathrm{kWh}$ \\
\hline Fuel cost & $\$ 2.52 /$ gallon $^{32}$ \\
\hline Diesel fuel cost escalation rate & $0.4 \% /$ year $^{33}$ \\
\hline Fuel available & 250 gallons \\
\hline Minimum turndown & $30 \%$ \\
\hline Fuel curve slope (gal/kW/hr) & $0.072119^{34}$ \\
\hline Fuel curve intercept (gal/hr) & 0.435884 \\
\hline Availability & $\begin{array}{l}\text { Runs only during grid outages and scheduled maintenance testing. We } \\
\text { assume the generators do not participate in peak load management. }\end{array}$ \\
\hline \multicolumn{2}{|l|}{ Utility Assumptions } \\
\hline Electricity costs & See Appendix C for tariff details. \\
\hline Electricity cost escalation rate & $1.52 \% /$ year $^{35}$ \\
\hline \multicolumn{2}{|l|}{ Ownership and Financing } \\
\hline Ownership model & $\begin{array}{l}\text { NYC-DOE: Third party } \\
\text { FDNY: Direct ownership }\end{array}$ \\
\hline
\end{tabular}

${ }^{27}$ DG HUB. 2015. "Resilient Solar Photovoltaics (PV) Systems."

http://www.cuny.edu/about/resources/sustainability/SmartDGHubEmergencyPower/DecHardwareFactSheet.pdf.

${ }^{28}$ Ibid.

${ }^{29}$ Ibid.

${ }^{30}$ DG Hub Survey. 2015. www.cuny.edu/DGHub

${ }^{31}$ Rocky Mountain Institute. 2015. "Defection Economics: PV, Batteries, and the Grid." Presented May 7, 2015.

${ }^{32} \mathrm{https} / / / \mathrm{www}$. eia.gov/dnav/pet/pet_pri_gnd_dcus_y $35 \mathrm{ny}$ a.htm

${ }_{33}$ National Institute for Standards and Technology (NIST). 2015. "Energy Price Indices and Discount Factors for

Life-Cycle Cost Analysis- 2015." http://energy.gov/eere/femp/downloads/energy-price-indices-and-discount-

factors-life-cycle-cost-analysis-2015

${ }^{34}$ Based on Homer Pro 50-kW generator

${ }^{35}$ National Institute for Standards and Technology (NIST). 2015. "Energy Price Indices and Discount Factors for Life-Cycle Cost Analysis- 2015.” http://energy.gov/eere/femp/downloads/energy-price-indices-and-discount-

factors-life-cycle-cost-analysis-2015 


\begin{tabular}{|c|c|}
\hline & NYCHA: Third party \\
\hline Corporate tax rate & $35 \%$ \\
\hline Developer discount rate & $10 \%$ \\
\hline Off-taker discount rate & $3.1 \%$ \\
\hline \multicolumn{2}{|l|}{ Incentives } \\
\hline Investment Tax Credit (ITC) & $\begin{array}{l}\text { - Third-party ownership scenario: } \\
-\quad 30 \% \text { ITC applied to PV only; not applied to batteries because } \\
\text { they are not charged at least } 75 \% \text { from PV } \\
\text { - Direct ownership scenario: ITC not applied }\end{array}$ \\
\hline $\begin{array}{l}\text { Modified Accelerated Cost } \\
\text { Recovery System (MACRS) }\end{array}$ & $\begin{array}{l}\text { - Third-party ownership scenario: } 5 \text { year MACRS applied to PV } \\
\text { - Direct ownership scenario: MACRS not applied }\end{array}$ \\
\hline Net metering & $\begin{array}{l}\text { NYC-DOE: No } \\
\text { FDNY, NYCHA: Yes }\end{array}$ \\
\hline $\begin{array}{l}\text { NYSERDA NY-Sun incentive } \\
\text { for PV systems under } 200 \mathrm{~kW}\end{array}$ & $\$ 0.80 / \mathrm{W}$ for the first $50 \mathrm{~kW}$ and $\$ 0.50 / \mathrm{W}$ for the next $51-200 \mathrm{~kW}^{36}$ \\
\hline Property tax abatement & None (government property) \\
\hline $\begin{array}{l}\text { Solar Renewable Energy } \\
\text { Credit (SREC) }\end{array}$ & None \\
\hline \multicolumn{2}{|l|}{ Value Streams } \\
\hline Ancillary services & None $^{3 \prime}$ \\
\hline Demand response & $\begin{array}{l}\text { - NYC-DOE: The Susan Wagner High School participates in the DCAS } \\
\text { (NYISO) demand response program. Based on historical data, DCAS } \\
\text { estimates savings of } \$ 100 / \mathrm{kW} \text { reduced in each season (summer and } \\
\text { winter). Because the potential savings from peak demand } \\
\text { management are greater, and participating in the demand response } \\
\text { program would reduce battery availability for peak demand } \\
\text { management, in this analysis the potential demand response } \\
\text { revenues are not included. } \\
\text { - FDNY: No demand response; the system is too small to participate. } \\
\text { - NYCHA: No demand response; the system is too small to participate. }\end{array}$ \\
\hline Grid outage cost & $\begin{array}{l}\text { - FDNY: } \$ 917.43 / \text { hour } \\
\text { - NYCHA: } \$ 87.53 / \text { hour } \\
\text { - NYC-DOE: } \$ 68.97 / \text { hour }\end{array}$ \\
\hline
\end{tabular}

The costs modeled in this analysis include the installed cost of the PV, battery, and/or diesel generator. There may be additional costs associated with integrating these systems that are not included in the analysis. This is due to a lack of validated cost data. These may include:

\footnotetext{
${ }^{36}$ See NY-Sun Nonresidential Block Structure, Block 3: http://ny-sun.ny.gov/For-Installers/Megawatt-BlockIncentive-Structure.

${ }^{37}$ NYISO ancillary services program requires $1 \mathrm{MW}$ minimum. These sites are all $<210 \mathrm{~kW}$ so aggregation to meet this threshold is unlikely.
} 
- Building physical characteristics: Installation costs can vary based on the relative ease or difficulty of installing equipment and communication and controls. For example, ideal locations for electrical or communication and controls equipment may be mechanical and electrical rooms. If these spaces do not have enough room or working clearance, additional conduit runs or trenching may be necessary.

- Structure to house batteries and environmental controls: Environmental controls (cooling, ventilation, and filters) may be required to maintain the batteries within the manufacturer's recommended operating range. A shipping container or other structure to house the batteries may also be required if they cannot be stored inside the buildings.

- Automatic transfer switch: We assume a manual transfer switch would be installed to isolate the facility from the grid during a grid outage. This requires a person to physically flip a switch to transfer to the backup power system. The cost of the switch depends on the building voltage. An automated transfer switch could be included at additional cost. In either case, a brief outage will occur while the facility is switched from grid-connected mode to islanded mode, though in the case of the automated transfer switch, the outage would be of shorter duration (typically a few milliseconds to a few seconds).

- Critical load isolation: We did not include the cost of retrofitting the buildings with critical load panel(s). Depending on the electrical distribution infrastructure of the building, this cost can range from $\$ 10,000$ to $\$ 100,000^{38}$ or more for a building in $\mathrm{NYC}$, including design/permit, electrician's fees for re-wiring, transfer switches, and new critical load panels. It may be more cost-effective to supply the entire building rather than modify the electrical system. In this case, some loads would need to be manually turned off during islanding events. In other cases, the building may have already installed a critical load panel.

- Site controller: Using resilient PV and hybrid systems during grid outages may add cost beyond what is presented in this analysis, depending on the level of system integration that is required. While most bi-directional inverters on the market are already enabled for island operation, they are controlled differently in island mode. Some commercially available microgrid controllers may be easily configured to provide both grid-connected and island functionality while others may require significant system integration engineering and additional hardware for proper islanded operation of all resources. Depending on the out-ofthe-box capabilities of the site controller and the respective front end monitoring and control equipment on the PV inverter, battery, and diesel generator, this might add an additional $\$ 20,000$ or more ${ }^{39}$ in system integration costs to a project. There may also be some additional hardware costs for communication cables and devices on the order of $\$ 5,000-10,000 .^{40}$ If a standalone diesel generator is used to provide backup power, no additional monitoring or control costs are anticipated since controls are already built into the generator.

Additionally, it is important to note that actual demand savings may vary from predicted demand savings based on the actual battery control strategy used at the site. Because actual interval load data were not available for two of the three sites (the fire station and the school), load data were synthesized from models. There is some additional uncertainty in the results for these sites

\footnotetext{
${ }^{38}$ Email with energy company, 12/11/15.

${ }^{39}$ Email with energy company, 12/11/15.

${ }^{40}$ Conversation with Robert Butt, Senior Engineer, NREL, 12/14/15.
} 
because hour-to-hour load variation in actual load profiles may be different from those developed by the models.

There may also be additional value streams not included in this analysis. For example, for systems meeting certain requirements, NYPA's peak load management program offers payments for capacity and energy reductions during demand response events. ${ }^{41}$

\subsection{Value of Resiliency}

Many organizations have trouble quantifying the price they are willing to pay for having a source of continuous, reliable electricity. The challenge of valuing resiliency causes most PV and battery systems to be designed and installed based upon their expected economic return during normal grid-connected operation. Although these systems will provide some measure of added resiliency, often no hard monetary value is assigned to the added resiliency, which is to say that the systems are expected to "pencil-out" before resiliency is considered.

This analysis modeled a resiliency value stream within the REopt model in order to demonstrate how valuing resiliency impacts system sizing and project economics. In this study, we assume that the value of resiliency to a site is equal to the costs they incur during an outage. The cost of power interruptions for a facility is a site-specific cost that depends on a number of factors including frequency, duration, timing of outages, activities that take place in the facility, and availability of backup systems. To calculate a site-specific outage cost, the facility could add up the damages that it will experience as a result of a grid outage. Some facilities such as government organizations involved in life safety may be exposed to other second- and thirdorder damages (i.e., inability to treat wastewater, inability to dispatch firefighters, inability to react to criminal activity).

In general, there are two approaches to determining the cost of a grid interruption: macroscopic or microscopic. In the macroscopic approach, the value is based on national or utility-wide estimates of outage costs that have been experienced in the past. ${ }^{42}$ This method requires relatively little data, but may not capture site-specific values well. In the microscopic approach, the value is based on a survey of the site-specific installation of outage costs. ${ }^{43}$ This may be more accurate, but is much more time-consuming to determine.

To determine the value of resiliency for the facilities in this study, the team selected a macroscopic approach because it is widely applicable, replicable for other facilities, and could be applied without lengthy data collection activities at the site. The U.S. Department of Energy's (DOE) Interruption Cost Estimator (ICE) calculator was used ${ }^{44}$ to calculate outage costs that were used as a proxy for the value of resiliency for grid outages at each site based on utility reliability metrics and site characteristics.

\footnotetext{
${ }^{41}$ See. "The Power of Demand: Peak Load Management Program for Governmental Customers." http://www.nyc.gov/html/dem/downloads/pdf/PLM brochure.pdf.

${ }^{42}$ Sullivan, M., J. Schellenberg, and M. Blundell. 2015. Updated Value of Service Reliability Estimates for Electric Utility Customers in the United States. Berkeley, CA: LBNL. http://eetd.lbl.gov/sites/all/files/lbnl-6941e 0.pdf.

${ }^{43}$ Sullivan, M., and D. Keane. 1995. Outage Cost Estimation Guidebook EPRI. http://www.epri.com/abstracts/Pages/ProductAbstract.aspx?ProductId=TR-106082.

44 “Interruption Cost Estimate (ICE) Calculator." 2015. DOE. http://icecalculator.com/.
} 
The ICE calculator requires several inputs (Figure 21) to calculate outage costs, including reliability data. The New York State Department of Public Service releases a reliability report each year that includes the following values with and without major storms included: ${ }^{45}$

SAIFI is the average number of interruptions a customer experiences in a calendar year.

SAIDI is the average outage duration across all customers served.

CAIDI is the average outage duration per utility customer affected (in hours).

These values are reported by all regulated utilities in the country. A bestfit linear trend line shows that Con Edison grid outage duration and frequency with storms have been increasing over the past 14 years (see Figure 22).

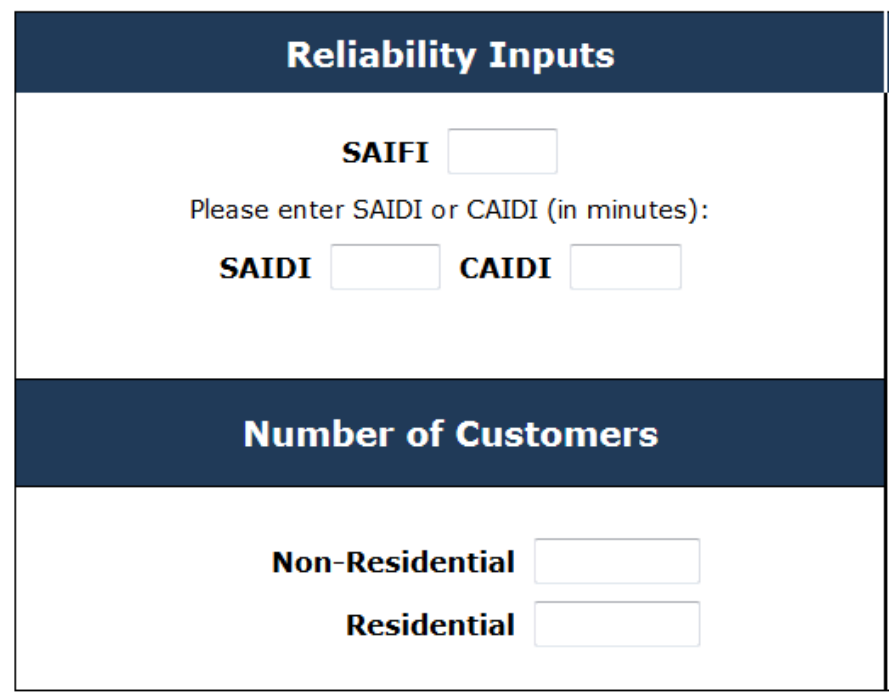

Figure 21. Screenshot of DOE ICE Calculator inputs

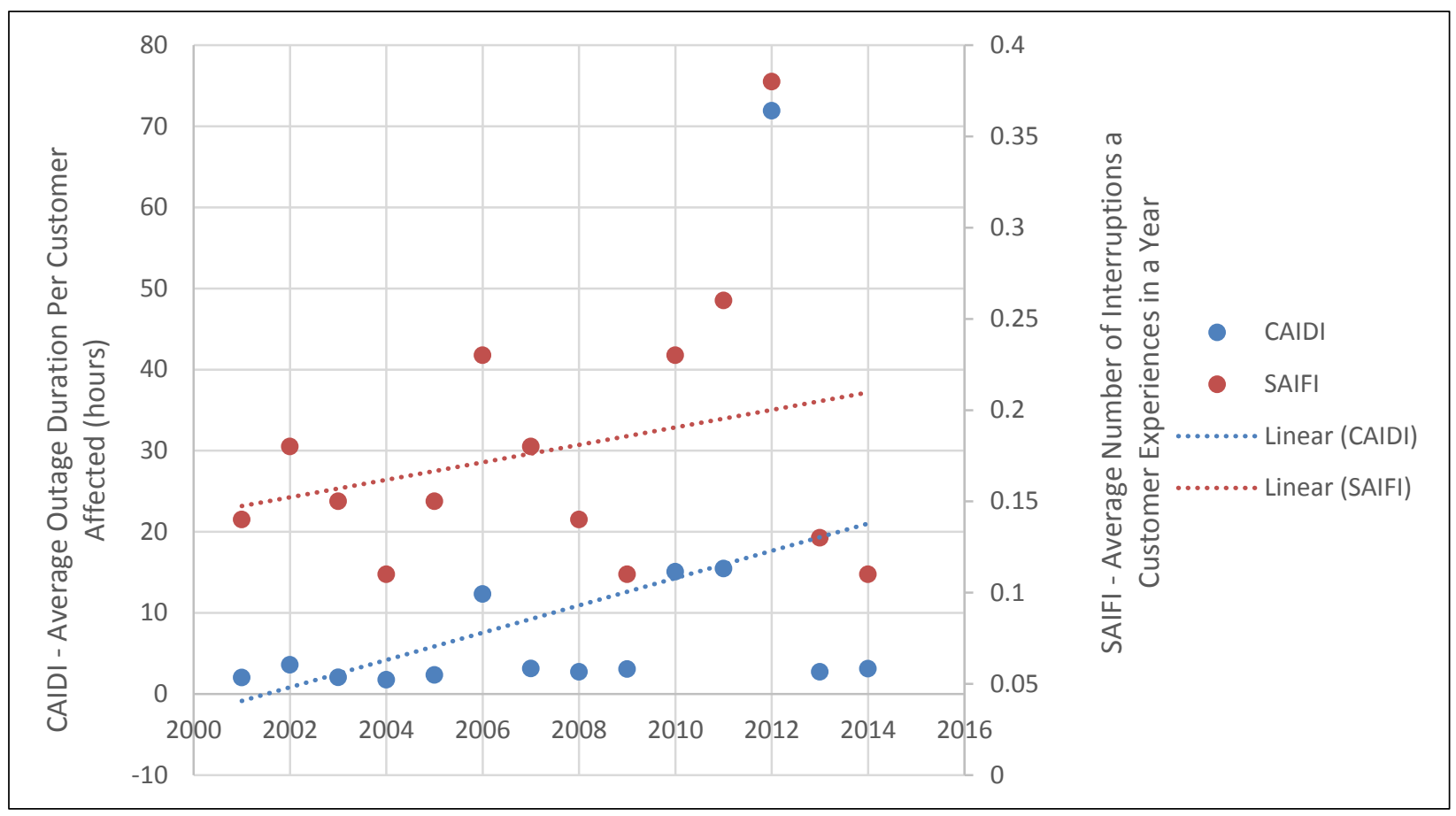

Figure 22. Con Edison system-wide grid reliability with storms

\footnotetext{
45 “Electric Service Reliability Reports.” 2015. New York State Department of Public Service. http://www3.dps.ny.gov/W/PSCWeb.nsf/All/D82A200687D96D3985257687006F39CA?OpenDocument.
} 
To appropriately represent the increasing frequency and duration of outages due to storms, the average reliability metrics from the past five years were used instead of the full 14-year data set. The frequency of outages (SAIFI) depends on if the facility is on the network or the radial grid. The values are summarized in the following table.

Table 8. Con Edison Five-Year Average SAIFI Values for Radial and Network Customers

\begin{tabular}{|l|l|}
\hline Grid Segment & SAIFI \\
\hline Radial & 0.77 \\
\hline Network & 0.04 \\
\hline
\end{tabular}

Two outage duration values (CAIDI) are evaluated: "with storm" grid statistics (hereafter referred to as a long duration outage) and "without storm" grid statistics (hereafter referred to as a short duration outage); they are summarized in Table 9. ${ }^{46}$ This establishes a lower and upper bound for grid outage duration for both the network and the radial grid, and establishes short and long outage cases for the analysis scenarios.

Table 9. Con Edison CAIDI Values for Radial and Network Customers

\begin{tabular}{|l|l|l|}
\hline \multicolumn{2}{|l|}{} & \multicolumn{2}{|l|}{$\begin{array}{l}\text { CAIDI } \\
\text { (hours/year) }\end{array}$} & $\begin{array}{l}\text { Technical } \\
\text { Analysis } \\
\text { Scenario }\end{array}$ \\
\hline Radial & 1.99 & Short \\
\hline Average year without storms (five-year average) & 11.88 & Long \\
\hline Average year with storms (five-year average) & 21 \\
\hline Network & 7.25 & Short \\
\hline Average year without storms (five-year average) & 7.25 & Long \\
\hline Average year with storms (five-year average) & 50.96 & \\
\hline
\end{tabular}

The facility specific costs of interruptions (i.e., annual value of resiliency) are developed using the U.S. DOE ICE Calculator. ${ }^{47}$ The ICE Calculator takes inputs of SAIFI, CAIDI, number of customers, customer class (residential, non-residential), location (state), average energy usage $(\mathrm{MWh})^{48}$, industry type, backup capabilities, and distribution of outages by time of day (percentage). Using the reliability metrics shown above, an outage cost vs. duration table is developed for each of the facilities in the study (see cost curve tables in Appendix B). The "Unit Cost of Interruption" is averaged over the 16-hour range that the ICE Calculator is able to analyze to provide an average hourly cost of interruption.

\footnotetext{
${ }^{46}$ The National Electric Code (NEC) requires that emergency and standby power systems supply power within a specified number of seconds and for a specified amount of time. The outage durations in this analysis are derived from Con Edison historical outage data, rather than from the NEC.

47 "Interruption Cost Estimate (ICE) Calculator." 2015. DOE. http://icecalculator.com/.

${ }^{48}$ Critical load that is supported during a grid outage.
} 
Table 10 summarizes the hourly cost of interruptions, or value of providing resiliency, for the facilities included in the study. Additional information is provided in Appendix B.

Table 10. Value of Resiliency for Study Facilities

\begin{tabular}{|c|c|c|c|c|}
\hline Site & $\begin{array}{l}\text { Value of Resiliency } \\
\text { Provided } \\
\text { (\$/hour/year) }\end{array}$ & & $\begin{array}{l}\text { ual Cost of } \\
\text { rt Duration } \\
\text { age } \\
7 \text { hours) }\end{array}$ & $\begin{array}{l}\text { Annual Cost of } \\
\text { Long Duration } \\
\text { Outage } \\
\text { (22 or } 51 \text { hours) }\end{array}$ \\
\hline NYC-DOE School Shelter (network) & 68.97 & $\$$ & 500.19 & $\$ 3,515.15$ \\
\hline FDNY Fire Station (radial) & 917.43 & $\$$ & $1,823.85$ & $\$ \quad 20,071.51$ \\
\hline NYCHA Cooling Center (network) & 32.02 & $\$$ & 232.15 & $\$ \quad 1631.74$ \\
\hline
\end{tabular}

Due to variation in load, solar resource, and battery state of charge, the amount of time a given resilient PV system can sustain the load during an outage varies by time of day and time of year. For each site, a series of 8760 simulations were performed to calculate the number of hours a resilient PV system could sustain the critical load for outages beginning during every hour of the year. The average number of hours the system can be expected to maintain the load was calculated from the results of these 8,760 simulations, and is defined as a resiliency metric $R$. Parametric sweeps were performed to calculate a range of $R$ values for various PV and storage sizes, and then a multi-variate regression analysis was conducted to calculate regression coefficients for the PV and storage components. For Scenario 1, the value of resiliency was incorporated into the optimization of system size based on the regression coefficients, hourly cost of interruptions, and expected annual outage duration. ${ }^{49}$

\subsection{Analysis Approach}

NREL's REopt model was used to size and dispatch PV, battery, and/or generator systems in four scenarios including both economic and resiliency benefits:

1. Scenario 1: Resilient PV sized for economic savings; no resiliency requirement imposed

The model chose from solar and storage resources to size resilient PV systems that are cost-effectivefor the host site while grid-connected, and then evaluated the resiliency benefits these systems provided.

\section{Scenario 2: Resilient PV sized to meet resiliency needs}

The model chose from solar and storage resources to size resilient PV systems capable of sustaining critical electric loads for short and long outages, and then evaluated the gridconnected economic benefit that these systems provide during normal grid operations.

\section{Scenario 3: Resilient PV and a generator (hybrid system) sized to meet resiliency} needs

The model chose from solar, storage, and diesel generator resources to size hybrid systems capable of sustaining critical electric loads for short and long outages, and then

\footnotetext{
${ }^{49}$ Simpkins, T., K. Anderson, D. Cutler, and D. Olis. 2016. “Optimal Sizing of a Solar-Plus-Storage System For Utility Bill Savings and Resiliency Benefits," accepted for publication in Proc. $7^{\text {th }}$ Conf. on Innovative Smart Grid Technologies, Minneapolis, MN.
} 
evaluated the grid-connected economic benefit that these systems provide during normal grid operations.

\section{Scenario 4: Generator sized to meet resiliency needs}

The model sized a diesel generator to support critical electric loads for short and long outages.

In this analysis, cost-effective means that the modeled system has an NPV that is equal to or greater than zero, and thus provides lifecycle cost savings to the site. Building owners may have other measures of cost-effectiveness such as lowest initial capital cost. While initial cost is presented in our results, systems are selected based on maximizing lifecycle cost savings, not lowest first cost.

Given NYC's commitment to install solar on city-owned buildings in order to reduce emissions, when the cost-optimal system did not include solar as part of the solution in Scenarios 1-3, any positive life cycle cost savings attainable by a battery-only system were used to offset the cost of solar and incorporate it into the recommended system, up to the point that NPV reached zero or all available space for solar was filled. This allows NYC to understand the combined impacts of solar and storage for cost savings and resiliency when installed together, and demonstrates how storage can facilitate implementation of PV systems that would not be cost-effective on their own.

In each scenario, the resilient PV system was able to operate for financial benefits during gridtied operation and was also able to serve the critical loads during grid outages. The generator was only able to operate during the outage. We modeled each scenario both with and without a resiliency value to understand the impact of valuing resiliency has on system sizing (for scenario 1) and economics (for all scenarios). We modeled Scenarios 2-4 with two different outage lengths (a short and long duration outage, described in Section 2.4) to demonstrate how system sizing and economics change with varying outage lengths.

Since the solar resource and critical load are both time-varying, the size of the resilient PV system required to sustain the critical load will be different depending on when the outage begins. For example, an outage occurring in the spring when loads are lower may require a smaller system than one occurring in the summer when loads are higher. To properly account for the stochastic nature of the critical load and the solar resource, the model should be run multiple times with the outage beginning at a different point in the year each time. The largest system required to sustain the critical load during this series of model runs would then represent the worst case, and could be assumed to meet the load during any of the other outages. Given the computational complexity of the model, for the purposes of this analysis we selected the period with the highest load and lowest solar generation to represent the worst case outage.

In this analysis, we assume the battery is fully charged at the time the outage occurs. Some outage events can be forecasted due to extreme weather, and in these cases the building owner may choose to charge the battery prior to the outage. Some outages cannot be predicted, and in this case, the assumption that the battery is fully charged is optimistic. A more thorough stochastic examination of the impact of battery state of charge is recommended for future work, but is not part of the scope of this analysis. 
We also assume that the battery will be replaced once during the 25 year project lifecycle, and the replacement cost is amortized into the upfront capital cost. The lifetime of the battery will depend on number of cycles and depth of discharge. A lithium ion battery may be expected to last ten to twelve years based on calendar degradation. A battery may not last the entire twelve years, however, if it is experiences an excessive number of deep charge / discharge cycles. Rather than include this effect in the model, we simply assume that the battery will last twelve years based on calendar degradation and then post-process the dispatch using the rainflow algorithm to verify the assumption ${ }^{50}$.

Each scenario is described in more detail below.

\section{Scenario 1: Resilient PV Sized for Economic Savings; no Resiliency Requirement Imposed}

In the first scenario, resiliency is not included as a design constraint; the optimal system configuration is based on achieving lowest life cycle cost assuming the grid is always available. In Scenario 1.1, system revenues are the utility savings, incentives, and tax benefits. Scenario 1.2 and 1.3 add a short and long outage resiliency value to the potential economic value streams.

Once the optimal sizes for the PV and/or battery system were determined based upon the revenue streams available, a series of simulations was conducted to assess the added resiliency benefit that such a system could achieve. The length of time for which the critical load could be sustained varies based on the state of charge of the battery, the solar resource, and the size of the critical load during the outage. For this analysis, we evaluated a "best case" and "worst case" outage period to show the maximum and minimum amount of resiliency the system could be expected to provide, where the best case was the period of lowest load and highest solar generation and the worst case was the period of highest load and lowest solar generation.

\section{Scenario 2: Resilient PV Sized to meet Resiliency Needs}

In the second scenario, we introduce resiliency as a design constraint. Rather than designing exclusively to maximize utility savings and policy incentives, we now require that the model identify a system that can sustain the critical load during specified outage lengths. Although the system is explicitly designed to sustain the specified outages, it can also be used for economic gain in normal operation, the same as in the first scenario. This scenario illustrates the incremental cost required when resiliency is added as a design constraint as well as the incremental benefit of avoiding outage costs. We look at a short (Scenario 2.1) and a long (Scenario 2.2) outage length, and evaluate each with and without assigning a value to resiliency.

\section{Scenario 3: Resilient PV and a Generator (Hybrid System) Sized to meet Resiliency Needs}

The third scenario is essentially the same as the second except that the candidate pool of technologies now includes a diesel generator in addition to the PV and battery. The model is constrained to operating the diesel generator only during grid outages while the PV and storage can operate both during outages and when the grid is operational.

\footnotetext{
${ }^{50}$ S.D. Downing, and D.F. Socie, Simple Rainflow Counting Algorithms; International Journal of Fatigue; 1982.
} 


\section{Scenario 4: Generator Sized to meet Resiliency Needs}

The fourth scenario considers a diesel-only case which is essentially the same as the second and third scenarios except that the candidate pool of technologies now includes only a diesel generator. Generators in this analysis were unable to participate in demand response due to small system sizes and the complexities of siting and operating a generator for demand response.

Scenario 4 is included for completeness and to provide a cost comparison of the various options for ensuring resiliency of the site.

The scenarios are summarized in Table 11.

While energy efficiency, natural gas generators, combined heat and power and other distributed generation resources may also offer economic and resiliency benefits, these were not modeled due to time and funding limitations. 
Table 11. Scenarios

\begin{tabular}{|c|c|c|c|}
\hline Scenario & Description & $\begin{array}{l}\text { Outage } \\
\text { Length }\end{array}$ & $\begin{array}{l}\text { Resiliency } \\
\text { Valued }\end{array}$ \\
\hline 1.1 & $\begin{array}{l}\text { Resilient PV sized for economic savings; no resiliency } \\
\text { requirement imposed }\end{array}$ & $\mathrm{N} / \mathrm{A}$ & No \\
\hline 1.2 & $\begin{array}{l}\text { Resilient PV sized for economic savings; no resiliency } \\
\text { requirement imposed }\end{array}$ & $\begin{array}{l}\text { Short }- \text { not } \\
\text { required }\end{array}$ & Yes \\
\hline 1.3 & $\begin{array}{l}\text { Resilient PV sized for economic savings; no resiliency } \\
\text { requirement imposed }\end{array}$ & $\begin{array}{l}\text { Long }- \text { not } \\
\text { required }\end{array}$ & Yes \\
\hline 2.1.a & Resilient PV sized to meet resiliency needs & Short & No \\
\hline 2.1.b & Resilient PV sized to meet resiliency needs & Short & Yes \\
\hline 2.2.a & Resilient PV sized to meet resiliency needs & Long & No \\
\hline 2.2.b & Resilient PV sized to meet resiliency needs & Long & Yes \\
\hline 3.1.a & Resilient PV + generator sized to meet resiliency needs & Short & No \\
\hline 3.1.b & Resilient PV + generator sized to meet resiliency needs & Short & Yes \\
\hline 3.2.a & Resilient PV + generator sized to meet resiliency needs & Long & No \\
\hline 3.2.b & Resilient PV + generator sized to meet resiliency needs & Long & Yes \\
\hline 4.1.a & Generator only sized to meet resiliency needs & Short & No \\
\hline 4.1.b & Generator only sized to meet resiliency needs & Short & Yes \\
\hline 4.2.a & Generator only sized to meet resiliency needs & Long & No \\
\hline 4.2.b & Generator only sized to meet resiliency needs & Long & Yes \\
\hline
\end{tabular}




\section{Results}

A summary of REopt results for each of the four scenarios is presented in this section for all three sites. See Appendix D for comprehensive results for each site.

The costs presented in this section may not include additional integration costs, such as critical load isolation or those that result from physical building characteristics, as outlined in Section 2.3. Any increases in cost would impact project economics.

\subsection{NYC-DOE High School/Coastal Storm Shelter \\ Scenario 1: Resilient PV Sized for Economic Savings; no Resiliency Requirement Imposed}

A high-level summary of system sizing and costs for Scenario 1 are below in Table 12.

Table 12. School Shelter Scenario 1 Results

\begin{tabular}{|l|r|r|r|}
\hline \multicolumn{7}{|c|}{ School Shelter } \\
\hline \multicolumn{7}{|c|}{ Scenario 1: PV + Storage Sized for Economic Savings } \\
\hline & $\begin{array}{l}\text { System 1.1: No } \\
\text { resiliency value } \\
\text { included }\end{array}$ & $\begin{array}{l}\text { System 1.2: Short- } \\
\text { duration resiliency } \\
\text { value included }\end{array}$ & $\begin{array}{l}\text { System 1.3: Long- } \\
\text { duration resiliency } \\
\text { value included }\end{array}$ \\
\hline PV Size (kW-DC) & 50 & 50 & 50 \\
\hline Battery Size (kWh) & 74 & 74 & 74 \\
\hline Battery Size (kW) & 35 & 35 & 35 \\
\hline Total Capital Cost & $\$ 205,716$ & $\$ 205,716$ & $\$ 205,716$ \\
\hline NPV & $\$ 51,560$ & 13.9 & $\$ 58,650$ \\
\hline Simple Payback (years) & 14.3 & & 13.9 \\
\hline
\end{tabular}

System 1.1 is a traditional economic analysis that does not include a resiliency value stream. This system would save the school $\$ 51,000$ over 25 years, which represents about $1 \%$ savings over the base case life cycle cost (see Appendix D). Because the resiliency value for network grid customers is relatively low, allowing the system to capture resiliency benefits in Systems 1.2 and 1.3 does not change the system size, but does reduce the payback period by 0.4 years and increases the NPV by about $14 \%(\$ 7,000)$.

Though this site can accommodate over $200 \mathrm{~kW}$ of solar, the economically optimal size solar array selected by the model is $50 \mathrm{~kW}$-DC due in part to the NY-Sun incentive modeled at $\$ 0.80 / \mathrm{W}$ for the first $50 \mathrm{~kW}$ and $\$ 0.50 / \mathrm{W}$ for the next $51-200 \mathrm{~kW}$. Unlike the other two sites modeled in this analysis, solar at the school shelter was selected as an economically optimal solution without requiring storage savings to offset solar costs. This is due to a lower cost of solar assumed for larger systems at this site and ample roof space. The assumed third-party ownership of the system at this site also allows the school to benefit from the federal tax incentives the developer would capture.

For all three cases, savings are attained by managing demand during peak periods. This is shown in Figure 23 where the battery is strategically discharged to reduce peak loads. 


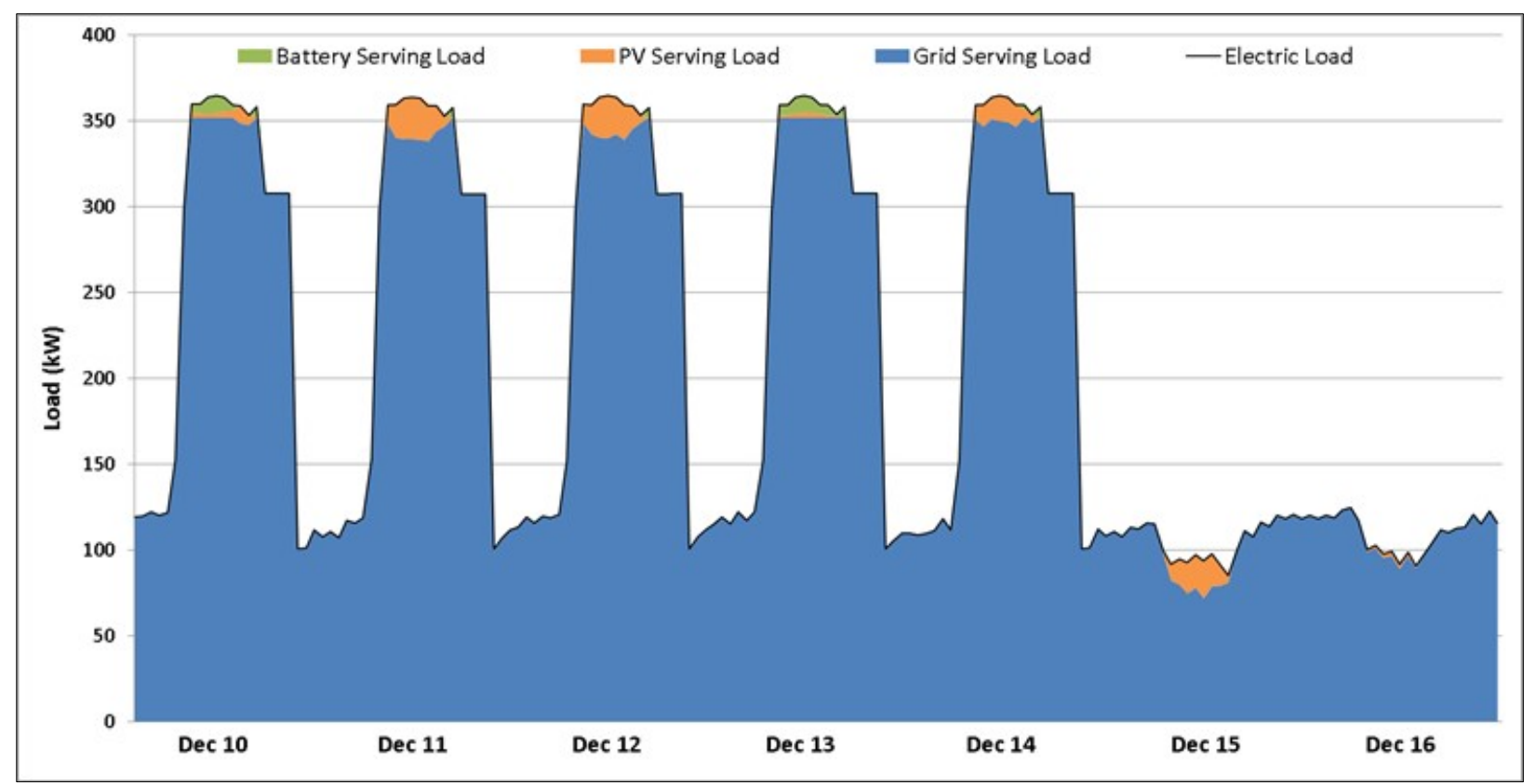

Figure 23. PV and battery combine to reduce peak demand

Because the school is on a spot network ${ }^{51}$, exported energy can be problematic, so net metering savings were not factored into the analysis. A reverse power relay could be installed to prevent export at an estimated cost of $\$ 5,000$. The school could alternatively implement a smart grid solution $^{52}$ to allow export. However, the smart grid solution costs $\$ 50,000-100,000$, and the exported power for the maximum solar array $(210 \mathrm{~kW})$ is only worth about $\$ 500 /$ year $(\$ 12,500$ over 25 years), so in this case, the reverse power relay to prevent export is a better economic choice.

The school participates in both the summer and winter DCAS demand response programs through NYPA. Potential revenues are approximately $\$ 100 / \mathrm{kW}$ of demand reduced in each season. Historically, the school has committed $25 \mathrm{~kW}$ of demand response in the summer (for revenue of approximately $\$ 2,500$ ) and $10 \mathrm{~kW}$ in the winter (for revenue of approximately $\$ 1,000)$.

\footnotetext{
${ }^{51}$ A spot network is a utility installation designed with multiple high-voltage feeders and transformers tied to a common bus to ensure reliable electric service for large electric load users. The network protectors on these transformers are designed with an automatic safety feature where the network protector will open when energy feeds back from the low-voltage bus toward the high-voltage feeder, which is indicative of a fault on the high-voltage cable. If a PV system were installed on a spot network and solar production were to exceed building load at any given time, the network protectors would sense the export of PV power as conditions analogous to those during a high-voltage feeder fault and would open automatically, causing the electricity service to that building to go out. ${ }^{52}$ There are two options when installing PV on a spot network. First, a reverse power relay can be installed to trip solar inverters offline whenever incoming power drops below a certain minimum amount in order to prevent any possibility of back feed of power to the network protectors. This costs approximately $\$ 5,000-10,000$. Second, if export of solar is desired, a smart grid solution including lightening the sensitivity of the network protectors to prevent them from opening under normal PV export conditions, installing SCADA monitoring and communications equipment, and anti-islanding relays can be installed. This costs approximately $\$ 50,000-100,000$.
} 
The school could potentially use the battery to increase its commitment to the demand response program. In theory, if the battery were fully charged each time the demand response call was issued, and the required demand reduction period was short enough that the battery could discharge at full capacity for the whole window, the $35-\mathrm{kW}$ battery could potentially save the school $\$ 3,500$ in the summer and $\$ 3,500$ in the winter for a total of $\$ 7,000 /$ year.

These potential revenues are significant, but less than the savings the battery provides by managing peak demand. The battery saves the school about $\$ 14,000 /$ year through peak demand management. If the battery is being used for peak demand management, it is unlikely the full battery capacity will be available to participate in demand response programs. Some of the battery capacity could be re-allocated away from peak management toward demand response in order to capture demand response revenues, but this would likely reduce peak demand management revenues.

It may be possible to use the battery for peak demand management while also allocating a portion of its capacity to demand response. Optimizing the use of the battery for simultaneous peak demand management and demand response requires detailed modeling of the demand response program, including the expected date and length of demand response calls and the payment available for each of those calls. This is beyond the scope of this analysis. For purposes of this analysis, we assume that the battery will be used for peak demand management rather than demand response since peak demand management provides a higher value stream.

Next, we evaluated the length of time that the 50-kW PV and 35-kW/74-kWh battery system could sustain the critical load during a short outage of 7 hours and a long outage of 51 hours. For the short outage, under the worst case scenario (low PV and high load), the system can support the full critical load for 3.1 hours, or $46 \%$ of the critical load for the entire 7 hours. Under the best case scenario (high PV and low load), the system can power additional loads beyond those designated as critical. For the long outage, under the worst case scenario (low PV and high load), the system can support the full critical load for 6 hours, or $12 \%$ of the critical load for 51 hours. Under the best case scenario (high PV and low load), the system can support the full critical load for 31 hours, or support $50 \%$ of the critical load for 51 hours; see Table 13.

Table 13. Percent of Critical Load System Can Support

\begin{tabular}{|l|r|r|r|}
\hline & $\begin{array}{l}\text { System 1.1: No } \\
\text { resiliency value } \\
\text { captured }\end{array}$ & $\begin{array}{l}\text { System 1.2: Short- } \\
\text { duration resiliency } \\
\text { value captured }\end{array}$ & $\begin{array}{l}\text { System 1.3: Long- } \\
\text { duration resiliency } \\
\text { value captured }\end{array}$ \\
\hline 7-Hour Outage (Worst) & $46 \%$ & $46 \%$ & $46 \%$ \\
\hline 7-Hour Outage (Best) & $285 \%$ & $285 \%$ & $12 \%$ \\
\hline 51-Hour Outage (Worst) & $12 \%$ & $50 \%$ & $50 \%$ \\
\hline 51-Hour Outage (Best) & $50 \%$ & $285 \%$ \\
\hline
\end{tabular}




\section{Scenario 2: Resilient PV Sized to meet Resiliency Needs}

A high-level summary of system sizing and costs for Scenario 2 are below in Table 14 .

Table 14. School Shelter Scenario 2 Results

\begin{tabular}{|l|r|r|r|r|}
\hline \multicolumn{7}{|c|}{ School Shelter } \\
\hline & $\begin{array}{l}\text { System 2.1A: } \\
\text { Short outage; } \\
\text { resiliency not } \\
\text { valued }\end{array}$ & $\begin{array}{l}\text { System 2.1B: } \\
\text { Short outage; } \\
\text { resiliency valued }\end{array}$ & $\begin{array}{l}\text { System 2.2A: } \\
\text { Long outage; } \\
\text { resiliency not } \\
\text { valued }\end{array}$ & $\begin{array}{l}\text { System 2.2B: } \\
\text { Long outage; } \\
\text { resiliency } \\
\text { valued }\end{array}$ \\
\hline PV Size (kW-DC) & 50 & 50 & 200 & 200 \\
\hline $\begin{array}{l}\text { Battery Size } \\
\text { (kWh) }\end{array}$ & 203 & 203 & 985 & 985 \\
\hline Battery Size (kW) & 68 & 68 & 158 & 158 \\
\hline Total Capital Cost & $\$ 306,282$ & $\$ 306,282$ & $\$ 1,244,758$ & $\$ 1,244,758$ \\
\hline NPV & $\$ 21,870$ & $\$ 30,570$ & $-\$ 523,480$ & $-\$ 462,330$ \\
\hline $\begin{array}{l}\text { Simple Payback } \\
\text { (years) }\end{array}$ & 12.0 & 11.7 & 18.4 & 17.5 \\
\hline
\end{tabular}

A cost-effective resilient PV system in Scenario 2 is possible with and without resiliency valued for short outages. Without resiliency valued, a system sized to cover the short outage would save the school $\$ 21,000$ over 25 years. This number increases by $40 \%$ to $\$ 30,000$ when a resiliency value stream is added.

In order to support a long outage, the size of the PV system increases by $300 \%$ and the battery capacity ( $\mathrm{kWh}$ ) increases by $385 \%$. The battery provides most of the energy to sustain the critical load, though the PV system provides some as well (see Figure 24). The NPV for both systems supporting a long outage is negative, again demonstrating that adding a resiliency value does not always have a large impact for network grid customers. 


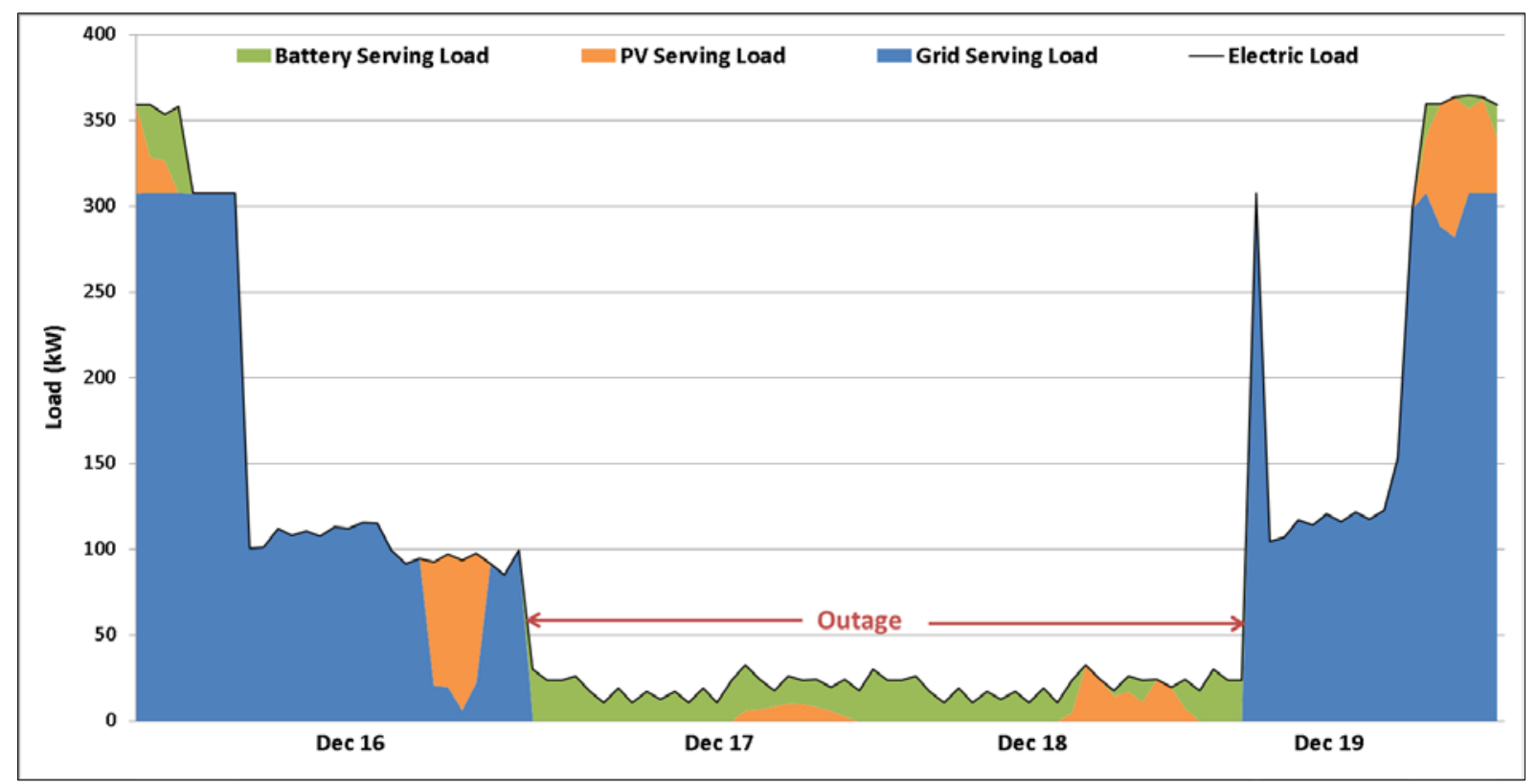

Figure 24. PV and battery support the critical load during a 51-hour outage

\section{Scenario 3: Resilient PV and a Generator (Hybrid System) Sized to meet Resiliency Needs}

A high-level summary of system sizing and costs for Scenario 3 are below in Table 15.

Table 15. School Shelter Scenario 3 Results

\begin{tabular}{|c|c|c|c|c|}
\hline \multicolumn{5}{|c|}{ School Shelter } \\
\hline \multicolumn{5}{|c|}{ Scenario 3: PV + Storage + Generator Sized for Resiliency } \\
\hline & $\begin{array}{l}\text { System 3.1A: } \\
\text { Short outage; } \\
\text { resiliency not } \\
\text { valued }\end{array}$ & $\begin{array}{l}\text { System 3.1B: } \\
\text { Short outage; } \\
\text { resiliency } \\
\text { valued }\end{array}$ & $\begin{array}{l}\text { System } 3.2 A \text { : } \\
\text { Long outage; } \\
\text { resiliency not } \\
\text { valued }\end{array}$ & $\begin{array}{l}\text { System 3.2B: } \\
\text { Long outage; } \\
\text { resiliency valued }\end{array}$ \\
\hline PV Size (kW-DC) & 50 & 50 & 50 & 50 \\
\hline $\begin{array}{l}\text { Battery Size } \\
\text { (kWh) }\end{array}$ & 118 & 118 & 87 & 87 \\
\hline Battery Size (kW) & 48 & 48 & 39 & 39 \\
\hline $\begin{array}{l}\text { Diesel Generator } \\
\text { Size }(\mathbf{k W})\end{array}$ & 10 & 10 & 18 & 18 \\
\hline $\begin{array}{l}\text { Diesel Fuel Used } \\
\text { (gallons/yr) }\end{array}$ & 8 & 8 & 88 & 88 \\
\hline Total Capital Cost & $\$ 255,974$ & $\$ 255,974$ & $\$ 244,331$ & $\$ 244,331$ \\
\hline NPV & $\$ 23,650$ & $\$ 32,350$ & $\$ 17,380$ & $\$ 78,530$ \\
\hline $\begin{array}{l}\text { Simple Payback } \\
\text { (years) }\end{array}$ & 14.5 & 14.1 & 15.5 & 12.7 \\
\hline
\end{tabular}


The results for Scenario 3 demonstrate that all four systems are cost-effective. By integrating a diesel generator into the PV and battery system, the school can sustain a longer outage period at much lower cost than if they were to use a PV and battery system alone. The school can save $\$ 17,000$ - $\$ 78,000$ over the 25 -year life of the system, depending on the length of outage the system is sized for and whether or not resiliency is valued. The resiliency value stream increases the NPV somewhat, especially in the long outage scenario (3.2B).

The size of the PV system remains at $50 \mathrm{~kW}$ across all four systems, again likely due to the reduction in the NY-Sun incentive above $50 \mathrm{~kW}$. However, the battery size decreases and generator increases when moving from the short to long outage. This is because a much larger battery would be required to sustain a long outage (as seen in 2.2.B). Peak demand management provides diminishing returns, and the savings from demand charge management do not offset the costs of a larger battery. The cost of additional fuel for the generator is relatively small (about $\$ 200$ for 80 gallons), so the model elects to use the generator instead. The PV and battery allow a smaller generator to cover the critical load (see Figure 25). The amount of fuel required to support a long outage increases ten-fold over short outage systems.

The capital cost for short-duration systems is slightly higher than long-duration total capital cost due to the larger battery size; however, the payback period is shorter for the short-duration systems. Third-party ownership was modeled for this site since NYC-DOE would likely use a PPA to implement the system, so upfront funding would not likely be a concern.

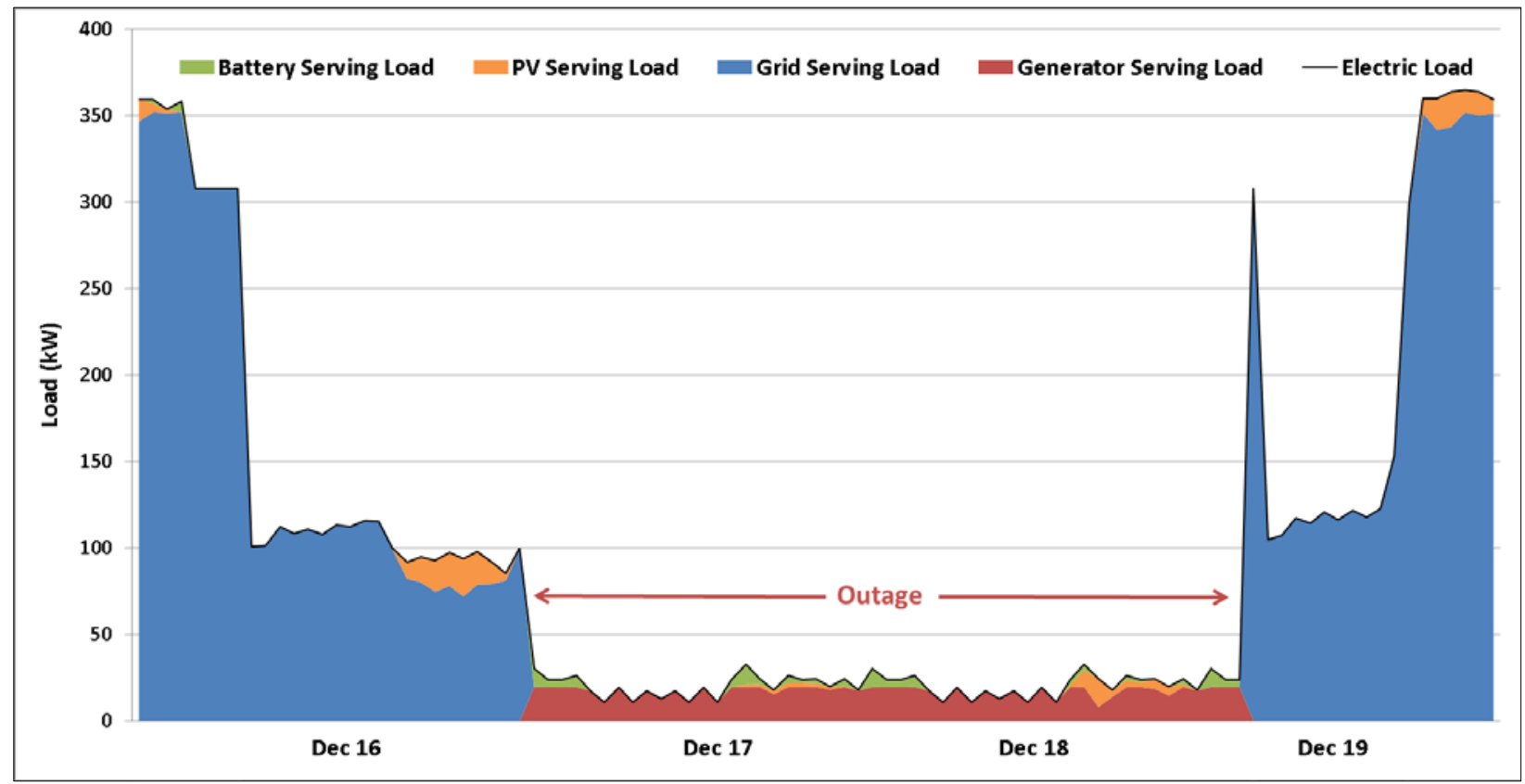

Figure 25. PV and battery reduce the size of generator required to meet the critical load during a 51-hour outage 


\section{Scenario 4: Generator Sized to meet Resiliency Needs}

A high-level summary of system sizing and costs for Scenario 4 are below in Table 16.

Table 16. School Shelter Scenario 4 Results

\begin{tabular}{|c|c|c|c|c|}
\hline \multicolumn{5}{|c|}{ School Shelter } \\
\hline \multicolumn{5}{|c|}{ Scenario 4: Generator Sized for Resiliency } \\
\hline & $\begin{array}{l}\text { System 4.1A: } \\
\text { Short outage; } \\
\text { resiliency not } \\
\text { valued }\end{array}$ & $\begin{array}{l}\text { System 4.1B: } \\
\text { Short outage; } \\
\text { resiliency } \\
\text { valued }\end{array}$ & $\begin{array}{l}\text { System 4.2A: } \\
\text { Long outage; } \\
\text { resiliency not } \\
\text { valued }\end{array}$ & $\begin{array}{l}\text { System 4.2B: } \\
\text { Long outage; } \\
\text { resiliency } \\
\text { valued }\end{array}$ \\
\hline $\begin{array}{l}\text { Diesel Generator } \\
\text { Size (kW) }\end{array}$ & 30 & 30 & 33 & 33 \\
\hline $\begin{array}{l}\text { Diesel Fuel Used } \\
\text { (gallons/yr) }\end{array}$ & 15 & 15 & 98 & 98 \\
\hline Total Capital Cost & $\$ 44,850$ & $\$ 44,850$ & $\$ 48,900$ & $\$ 48,900$ \\
\hline NPV & $-\$ 61,470$ & $-\$ 52,770$ & $-\$ 63,550$ & $-\$ 2,400$ \\
\hline $\begin{array}{l}\text { Simple Payback } \\
\text { (years) }\end{array}$ & None & None & None & 14.9 \\
\hline
\end{tabular}

The NPV for all four systems in Scenario 4 is negative, and only system 4.2B has a simple payback when resiliency is valued. System size and capital cost do not increase much when moving from short to long outages, but the amount of fuel required increases by 83 gallons $(550 \%)$.

\section{Discussion of School Shelter Results Across All Scenarios}

Table 17 compares the NPV and simple payback for the three scenarios (2-4) that size systems for resiliency. The highest NPV and quickest payback in each column is highlighted in green, as is the row with the most green cells, to represent the system with the best economics overall. Looking across all the systems sized to support resiliency needs, Scenario 3 has the highest NPV and shortest payback period for systems designed to support long outages. Scenario 4 has the lowest upfront capital cost of all the scenarios, but NPV is negative in all four cases. 
Table 17. School Shelter NPV and Payback Comparison of Scenarios 2, 3, and 4

\begin{tabular}{|c|c|c|c|c|}
\hline \multicolumn{5}{|c|}{ School Shelter } \\
\hline \multicolumn{5}{|c|}{ Most Cost-Effective Option for Outage Coverage } \\
\hline & $\begin{array}{l}\text { Short outage; } \\
\text { resiliency not } \\
\text { valued }\end{array}$ & $\begin{array}{l}\text { Long outage; } \\
\text { resiliency not } \\
\text { valued }\end{array}$ & $\begin{array}{l}\text { Short outage; } \\
\text { resiliency } \\
\text { valued }\end{array}$ & $\begin{array}{l}\text { Long outage; } \\
\text { resiliency } \\
\text { valued }\end{array}$ \\
\hline $\begin{array}{l}\text { Scenario 2: PV+Storage } \\
\text { NPV }\end{array}$ & $\$ 21,870$ & $-\$ 523,480$ & $\$ 30,570$ & $-\$ 462,330$ \\
\hline $\begin{array}{l}\text { Scenario 2: PV+Storage } \\
\text { Payback }\end{array}$ & 12.0 & 18.4 & 11.7 & 17.5 \\
\hline Scenario 3: Hybrid NPV & $\$ 23,650$ & $\$ 17,380$ & $\$ 32,350$ & $\$ 78,530$ \\
\hline $\begin{array}{l}\text { Scenario 3: Hybrid } \\
\text { Payback }\end{array}$ & 14.5 & 15.5 & 14.1 & 12.7 \\
\hline $\begin{array}{l}\text { Scenario 4: Generator } \\
\text { NPV }\end{array}$ & $-\$ 61,470$ & $-\$ 63,550$ & $-\$ 52,770$ & $-\$ 2,400$ \\
\hline $\begin{array}{l}\text { Scenario 4: Generator } \\
\text { Payback }\end{array}$ & N/A & N/A & N/A & 14.9 \\
\hline
\end{tabular}

\subsection{FDNY EC309}

\section{Scenario 1: Resilient PV Sized for Economic Savings; no Resiliency Requirement Imposed}

A high-level summary of system sizing and costs for Scenario 1 are below in Table 18.

Table 18. Fire Station Scenario 1 Results

\begin{tabular}{|c|c|c|c|}
\hline \multicolumn{4}{|c|}{ Fire Station } \\
\hline \multicolumn{4}{|c|}{ Scenario 1: PV + Storage Sized for Economic Savings } \\
\hline & $\begin{array}{l}\text { System 1.1: No } \\
\text { resiliency value } \\
\text { captured }\end{array}$ & $\begin{array}{l}\text { System 1.2: Short } \\
\text { duration resiliency } \\
\text { value captured }\end{array}$ & $\begin{array}{l}\text { System 1.3: Long } \\
\text { duration resiliency } \\
\text { value captured }\end{array}$ \\
\hline PV Size (kW-DC) & 10 & 10 & 10 \\
\hline Battery Size (kWh) & 43 & 43 & 213 \\
\hline Battery Size (kW) & 16 & 16 & 31 \\
\hline Total Capital Cost & $\$ 69,413$ & $\$ 69,413$ & $\$ 172,741$ \\
\hline NPV & $\$ 22,365$ & $\$ 54,132$ & $\$ 324,250$ \\
\hline Simple Payback (years) & 15.9 & 10.5 & 6.1 \\
\hline
\end{tabular}

System 1.1 is a traditional economic analysis that does not include a resiliency value stream. This system would save the fire station $\$ 22,000$ over 25 years, which represents about $5.1 \%$ savings over the base case life cycle cost. When the system is able to capture a resiliency value for a short duration outage (approximately 2 hours/year in this case), the system size remains the same, but the payback period is reduced by 5.4 years. System 1.3 is able to capture a resiliency value for a long duration outage (approximately 22 hours/year), which increases the battery storage size by $495 \%$ and reduces the payback period by an additional 4.4 years. 
For all three cases, savings are attained by managing demand during peak periods. This is shown in Figure 26, where the battery is strategically discharged to reduce peaks.

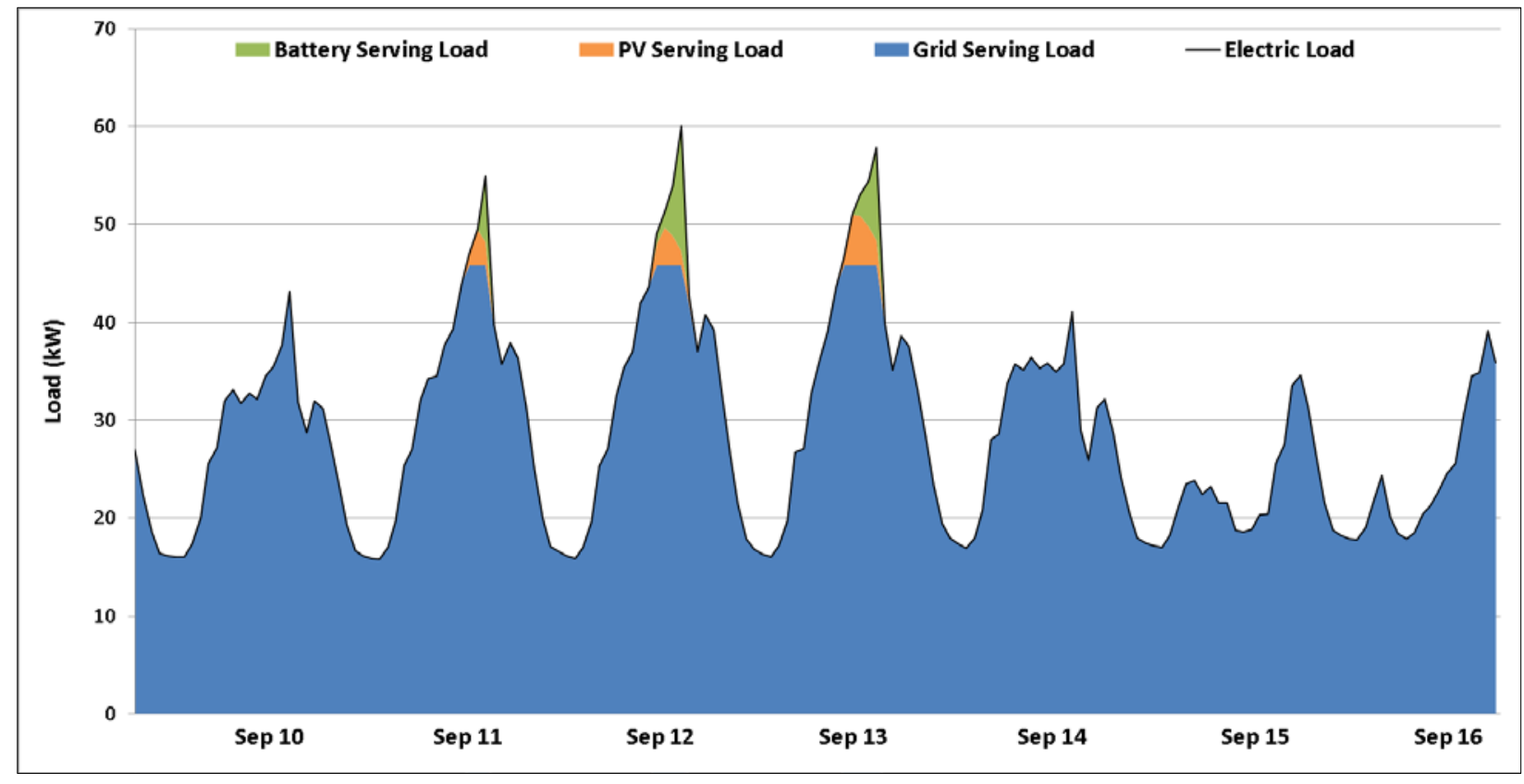

Figure 26. PV and battery combine to reduce peak demand at the fire station

Next, we evaluated the length of time that the PV and battery system could sustain the critical load during a short outage of 2 hours and a long outage of 22 hours. Because the PV and battery in this scenario are relatively small compared to the load, the battery cannot always sustain the full critical load. Systems 1.1 and 1.2 do not have an inverter large enough to support the full critical load in the worst case scenario. However, these systems could support $41 \%$ of the critical load for a 2-hour outage under the worst case scenario (low PV and high load), and could support additional loads (beyond just the critical load) under the best case scenario (high PV and low load). The systems could support $2 \%$ of the critical load for a 22 -hour outage under the worst case scenario and $73 \%$ under the best case scenario. System 1.3 could support $77 \%$ of the load for a 2 hour outage and $47 \%$ for a 22 hour outage under the worst case scenario. Under the best case scenario, additional loads in excess of the critical load can be supported; see Table 19.

Table 19. Percent of Critical Load System Can Support

\begin{tabular}{|l|l|l|l|}
\hline & $\begin{array}{l}\text { System 1.1: No } \\
\text { resiliency value } \\
\text { captured }\end{array}$ & $\begin{array}{l}\text { System 1.2: Short- } \\
\text { duration resiliency } \\
\text { value captured }\end{array}$ & $\begin{array}{l}\text { System 1.3: Long- } \\
\text { duration resiliency } \\
\text { value captured }\end{array}$ \\
\hline 2-Hour Outage (Worst) & $41 \%$ & $41 \%$ & $77 \%$ \\
\hline 2-Hour Outage (Best) & $732 \%$ & $732 \%$ & $1181 \%$ \\
\hline 22-Hour Outage (Worst) & $2.4 \%$ & $2.4 \%$ & $47 \%$ \\
\hline 22-Hour Outage (Best) & $73 \%$ & $73 \%$ & $264 \%$ \\
\hline
\end{tabular}




\section{Scenario 2: Resilient PV Sized to meet Resiliency Needs}

A high-level summary of system sizing and costs for Scenario 2 are below in Table 20.

Table 20. Fire Station Scenario 2 Results

\begin{tabular}{|c|c|c|c|c|}
\hline \multicolumn{5}{|c|}{ Fire Station } \\
\hline \multicolumn{5}{|c|}{ Scenario 2: PV + Storage Sized to Meet Resiliency Needs } \\
\hline & $\begin{array}{l}\text { System 2.1A: } \\
\text { Short outage; } \\
\text { resiliency not } \\
\text { valued }\end{array}$ & $\begin{array}{l}\text { System 2.1B: } \\
\text { Short outage; } \\
\text { resiliency } \\
\text { valued }\end{array}$ & $\begin{array}{l}\text { System 2.2A: } \\
\text { Long outage; } \\
\text { resiliency not } \\
\text { valued }\end{array}$ & $\begin{array}{l}\text { System 2.2B: } \\
\text { Long outage; } \\
\text { resiliency } \\
\text { valued } \\
\end{array}$ \\
\hline PV Size (kW-DC) & 0 & 10 & 10 & 10 \\
\hline $\begin{array}{l}\text { Battery Size } \\
\text { (kWh) }\end{array}$ & 136 & 131 & 613 & 613 \\
\hline Battery Size (kW) & 41 & 40 & 40 & 40 \\
\hline Total Capital Cost & $\$ 111,930$ & $\$ 138,828$ & $\$ 389,706$ & $\$ 389,706$ \\
\hline NPV & $-\$ 12,070$ & $\$ 10,149$ & $-\$ 256,158$ & $\$ 93,118$ \\
\hline $\begin{array}{l}\text { Simple Payback } \\
\text { (years) }\end{array}$ & 20.7 & 16.9 & N/A & 13.6 \\
\hline
\end{tabular}

Cost-effective $\mathrm{PV}+$ storage systems sized to meet resiliency needs were only possible when a resiliency value stream was included. The addition of a resiliency value stream for system $2.1 \mathrm{~B}$ results in a positive NPV of $\$ 10,000$, and allows PV to be incorporated into the solution. Without the resiliency value stream, the system has an NPV of negative $\$ 12,000$ (system 2.1A) and no $\mathrm{PV}$. The impact that valuing resiliency can have is seen even more clearly when the systems are required to support a long outage. The NPV of system $2.2 \mathrm{~A}$ is negative $\$ 256,000$, while the NPV of system $2.2 \mathrm{~B}$ is positive $\$ 93,000$.

A large amount of battery capacity is required because the PV system can only supply on average $14 \%$ of the daily energy required. Therefore, the battery has to store the remaining $86 \%$ of the energy required in advance of the outage. Since solar resources are limited to $10 \mathrm{~kW}$, sustaining a long outage requires a significant increase in battery capacity. Battery sizing for a 2hour outage requires 131-136 kWh of battery capacity while a 22-hour outage requires $613 \mathrm{kWh}$ of battery capacity, representing an increase of approximately $368 \%$; see Figure 27. 


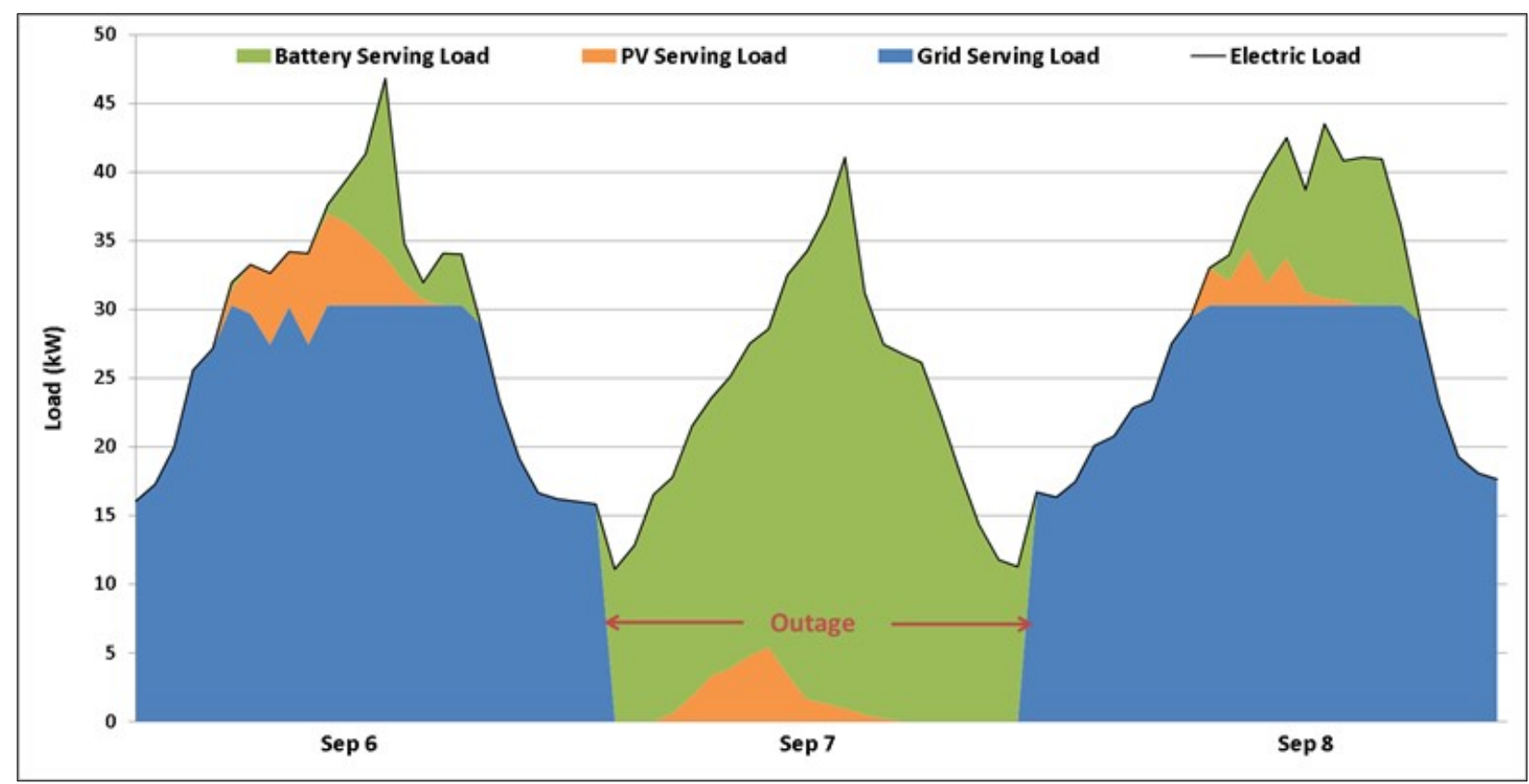

Figure 27. During a 21-hour grid outage on September 7th, the PV (orange) and battery (green) sustain the critical load

\section{Scenario 3: Resilient PV and a Generator (Hybrid System) Sized to meet Resiliency Needs}

A high-level summary of system sizing and costs for Scenario 3 are below in Table 21.

Table 21. Fire Station Scenario 3 Results

\begin{tabular}{|c|c|c|c|c|}
\hline \multicolumn{5}{|c|}{ Fire Station } \\
\hline \multicolumn{5}{|c|}{ Scenario 3: PV + Storage + Generator Sized to Meet Resiliency Needs } \\
\hline & $\begin{array}{l}\text { System 3.1A: } \\
\text { Short outage; } \\
\text { resiliency not } \\
\text { valued } \\
\end{array}$ & $\begin{array}{l}\text { System 3.1B: } \\
\text { Short outage; } \\
\text { resiliency valued }\end{array}$ & $\begin{array}{l}\text { System 3.2A: } \\
\text { Long outage; } \\
\text { resiliency not } \\
\text { valued }\end{array}$ & $\begin{array}{l}\text { System 3.2B: } \\
\text { Long outage; } \\
\text { resiliency valued }\end{array}$ \\
\hline PV Size (kW-DC) & 4 & 10 & 1 & 10 \\
\hline $\begin{array}{l}\text { Battery Size } \\
\text { (kWh) }\end{array}$ & 73 & 74 & 61 & 66 \\
\hline Battery Size (kW) & 18 & 18 & 17 & 20 \\
\hline $\begin{array}{l}\text { Diesel Generator } \\
\text { Size (kW) }\end{array}$ & 23 & 22 & 26 & 24 \\
\hline $\begin{array}{l}\text { Diesel Fuel Used } \\
\text { (gallons/yr) }\end{array}$ & 4 & 4 & 43 & 41 \\
\hline Total Capital Cost & $\$ 102,328$ & $\$ 120,505$ & $\$ 89,381$ & $\$ 121,164$ \\
\hline NPV & $\$ 0$ & $\$ 25,384$ & $-\$ 1,679$ & $\$ 344,848$ \\
\hline $\begin{array}{l}\text { Simple Payback } \\
\text { (years) }\end{array}$ & 19.3 & 15.4 & 19.8 & 4.7 \\
\hline
\end{tabular}


Adding a resiliency value stream provided savings that were used to offset the cost of adding additional solar to the system, increasing the PV system size from $4 \mathrm{~kW}$ to $10 \mathrm{~kW}$ and reducing the generator size by $1 \mathrm{~kW}$ in system 3.1B. When a resiliency value is included in the long outage scenario (3.2B), the payback period drops significantly over all the other systems in Scenario 3 to 4.7 years. This hybrid system is estimated to cost approximately $\$ 121,000$ to install (though there may be additional integration costs, described in Section 2), and would save FDNY approximately $\$ 344,000$ over the 25-year life cycle compared to the base case of doing nothing. When resiliency is not valued for a long outage, system 3.2A would cost FDNY under $\$ 2,000$ over the 25-year life cycle of the system. Assuming FDNY values resiliency at $\$ 2,000$ or more over 25 years, System 3.2A would also be cost-effective. By pairing resilient PV with the generator, the size of generator required to sustain the critical load is reduced from 41 to $24 \mathrm{~kW}$ (see Figure 28).

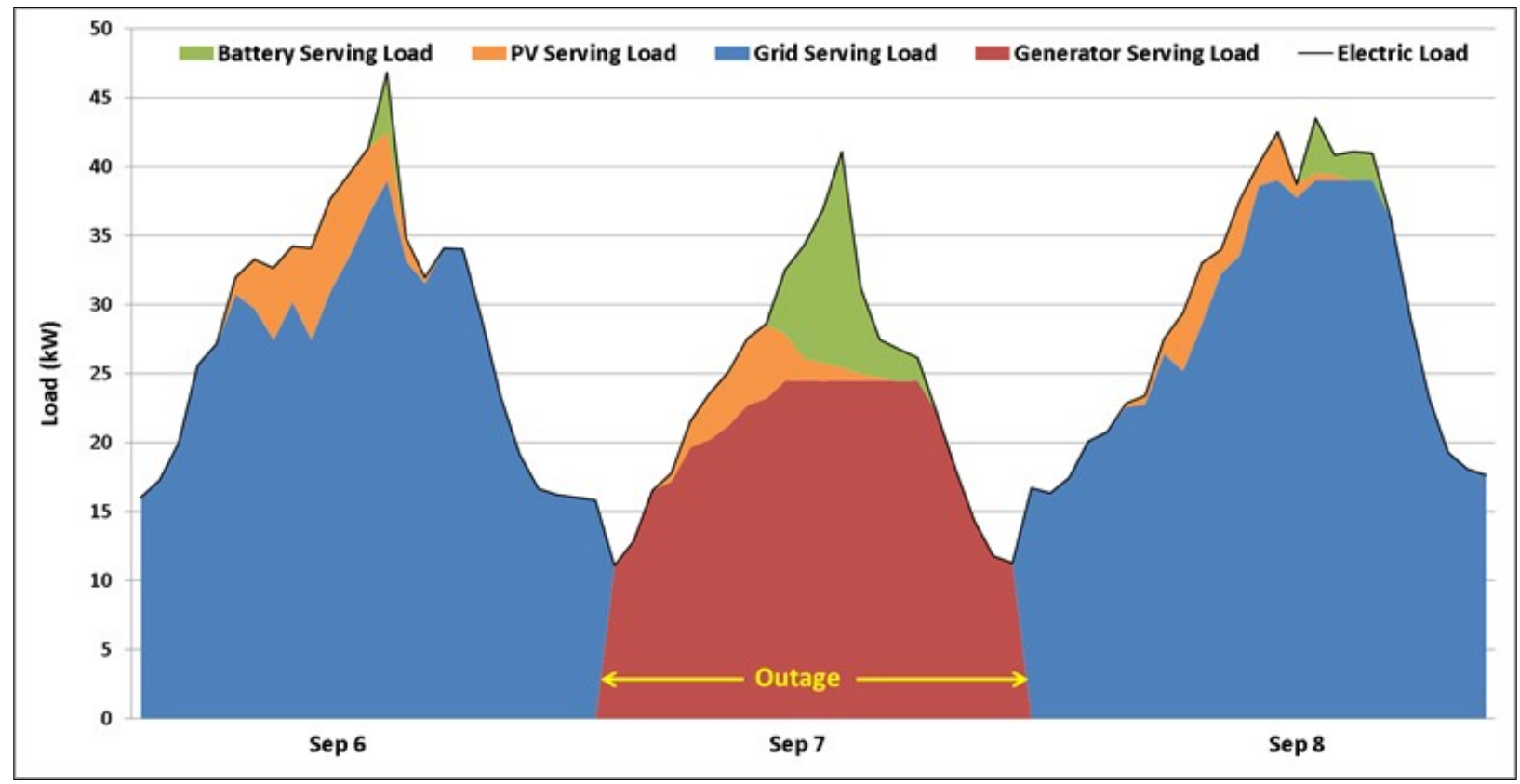

Figure 28. During a 21-hour grid outage on September 7th, the PV (orange) and battery (green) meet peak loads to reduce the size of generator required to sustain the critical load

\section{Scenario 4: Generator Sized to meet Resiliency Needs}

For comparison, we also evaluated the cost of a conventional diesel-only backup system. A highlevel summary of system sizing and costs for Scenario 4 are below in Table 22. 
Table 22. Fire Station Scenario 4 Results

Fire Station

Scenario 4: Generator Sized to Meet Resiliency Needs

\begin{tabular}{|l|r|r|r|r|}
\hline & $\begin{array}{l}\text { System 4.1A: } \\
\text { Short outage; } \\
\text { resiliency not } \\
\text { valued }\end{array}$ & $\begin{array}{l}\text { System 4.1B: } \\
\text { Short outage; } \\
\text { resiliency valued }\end{array}$ & $\begin{array}{l}\text { System 4.2A: } \\
\text { Long outage; } \\
\text { resiliency not } \\
\text { valued }\end{array}$ & $\begin{array}{l}\text { System 4.2B: } \\
\text { Long outage; } \\
\text { resiliency } \\
\text { valued }\end{array}$ \\
\hline $\begin{array}{l}\text { Diesel Generator } \\
\text { Size (kW) }\end{array}$ & 41 & 41 & 41 & 41 \\
\hline $\begin{array}{l}\text { Diesel Fuel Used } \\
\text { (gallons/yr) }\end{array}$ & 7 & 7 & 47 & 47 \\
\hline Total Capital Cost & 61,620 & 61,620 & 61,620 & 61,620 \\
\hline NPV & $-\$ 51,731$ & $-\$ 19,964$ & $-\$ 52,896$ & $\$ 296,380$ \\
\hline $\begin{array}{l}\text { Simple Payback } \\
\text { (years) }\end{array}$ & None & None & None & 3.0 \\
\hline
\end{tabular}

The size of the generator stays consistent at $41 \mathrm{~kW}$ across all 4 systems, but the amount of fuel increases from 7 gallons to 47 gallons when the outage duration is increased from 2 hours to 22 hours. The only system in Scenario 4 that is cost-effective is $4.2 \mathrm{~B}$, which includes a resiliency value for a long duration outage.

\section{Discussion of Fire Station Results Across All Scenarios}

Table 23 compares the NPV and simple payback for the three scenarios that size systems for resiliency. The highest NPV and quickest payback in each column is highlighted in green, as is the row with the most green cells, to represent the system with the best economics overall. With and without resiliency valued, and for both short and long outages, the hybrid system consistently resulted in the highest NPV and typically, the shortest payback.

Table 23. Fire Station NPV and Payback Comparison of Scenarios 2, 3, and 4

\begin{tabular}{|l|r|r|r|r|}
\hline \multicolumn{5}{|c|}{ Fire Station } \\
\hline & $\begin{array}{l}\text { Most Cost-Effective Option for Outage Coverage } \\
\text { Short outage; } \\
\text { resiliency not } \\
\text { valued }\end{array}$ & $\begin{array}{l}\text { Long outage; } \\
\text { resiliency not } \\
\text { valued }\end{array}$ & $\begin{array}{l}\text { Short outage; } \\
\text { resiliency } \\
\text { valued }\end{array}$ & $\begin{array}{l}\text { Long outage; } \\
\text { resiliency } \\
\text { valued }\end{array}$ \\
\hline & $-\$ 12,070$ & $-\$ 256,158$ & $\$ 10,149$ & $\$ 93,118$ \\
\hline $\begin{array}{l}\text { Scenario 2: } \\
\text { PV+Storage NPV }\end{array}$ & 20.7 & N/A & 16.9 & 13.6 \\
\hline $\begin{array}{l}\text { Scenario 2: } \\
\text { PV+Storage Payback }\end{array}$ & $\$ 0$ & $-\$ 1,679$ & $\$ 25,384$ & $\$ 344,848$ \\
\hline $\begin{array}{l}\text { Scenario 3: Hybrid } \\
\text { NPV }\end{array}$ & 19.3 & 19.8 & 15.4 & 4.7 \\
\hline $\begin{array}{l}\text { Scenario 3: Hybrid } \\
\text { Payback }\end{array}$ & $-\$ 51,713$ & $-\$ 51,713$ & $-\$ 19,964$ & $\$ 296,380$ \\
\hline $\begin{array}{l}\text { Scenario 4: Generator } \\
\text { NPV }\end{array}$ & N/A & N/A & N/A & 3.0 \\
\hline $\begin{array}{l}\text { Scenario 4: Generator } \\
\text { Payback }\end{array}$ & & & & \\
\hline
\end{tabular}


In the hybrid systems, the PV and battery provide demand savings during normal grid-tied operation and also sustain part of the critical load during outages, reducing the size of the generator required. The generator-only scenarios all required a $41-\mathrm{kW}$ generator while the generator sizing for the hybrid systems ranged from $22-26 \mathrm{~kW}$. Compared to the resilient PV systems in Scenario 2, the hybrid systems in Scenario 3 use a significantly reduced battery size $(131-613 \mathrm{kWh}$ vs. $61-74 \mathrm{kWh})$. Reliance on diesel fuel is reduced only minimally between Scenario 4 and Scenario 3; however, there is no reliance on diesel fuel in Scenario 2.

\subsection{NYCHA Cooling Center}

\section{Scenario 1: Resilient PV Sized for Economic Savings; no Resiliency Requirement Imposed}

A high-level summary of system sizing and costs for Scenario 1 are below in Table 24 .

Table 24. Cooling Center Scenario 1 Results

\begin{tabular}{|l|r|r|r|}
\hline \multicolumn{5}{|c|}{ Cooling Center } \\
\hline \multicolumn{5}{|c|}{ Scenario 1: PV + Storage Sized for Economic Savings } \\
\hline & $\begin{array}{l}\text { System 1.1: No } \\
\text { resiliency value } \\
\text { captured }\end{array}$ & $\begin{array}{l}\text { System 1.2: Short } \\
\text { duration resiliency } \\
\text { value captured }\end{array}$ & $\begin{array}{l}\text { System 1.3: Long } \\
\text { duration resiliency } \\
\text { value captured }\end{array}$ \\
\hline PV Size (kW-DC) & 7 & 8 & 8 \\
\hline Battery Size (kWh) & 25 & 25 & 25 \\
\hline Battery Size (kW) & 7 & 7 & 7 \\
\hline Total Capital Cost & $\$ 46,286$ & $\$ 50,120$ & $\$ 50,538$ \\
\hline NPV & $\$ 413$ & 15,683 & 11.1 \\
\hline Simple Payback (years) & 15.6 & 14.1 & \\
\hline
\end{tabular}

System 1.1 is a traditional economic analysis that does not include a resiliency value stream. This system would save the cooling center $\$ 413$ over 25 years, which presents essentially a breakeven case over the life of the system. When the system is able to capture a resiliency value for a short outage (approximately 7 hours/year in this case), the size of the battery remains the same and the additional revenue is used to offset the costs of a slightly larger 8-kW PV system. NPV increases and payback period is shortened by approximately one year. System 1.3 is able to capture a resiliency value for a long outage (approximately 51 hours/year), which results in a slight increase in battery size (less than $1 \mathrm{kWh}$ ) and reduces the payback period by an additional 3 years.

These savings are attained primarily by managing demand during peak periods. This is shown in Figure 29, where the battery is strategically discharged to reduce peaks. 


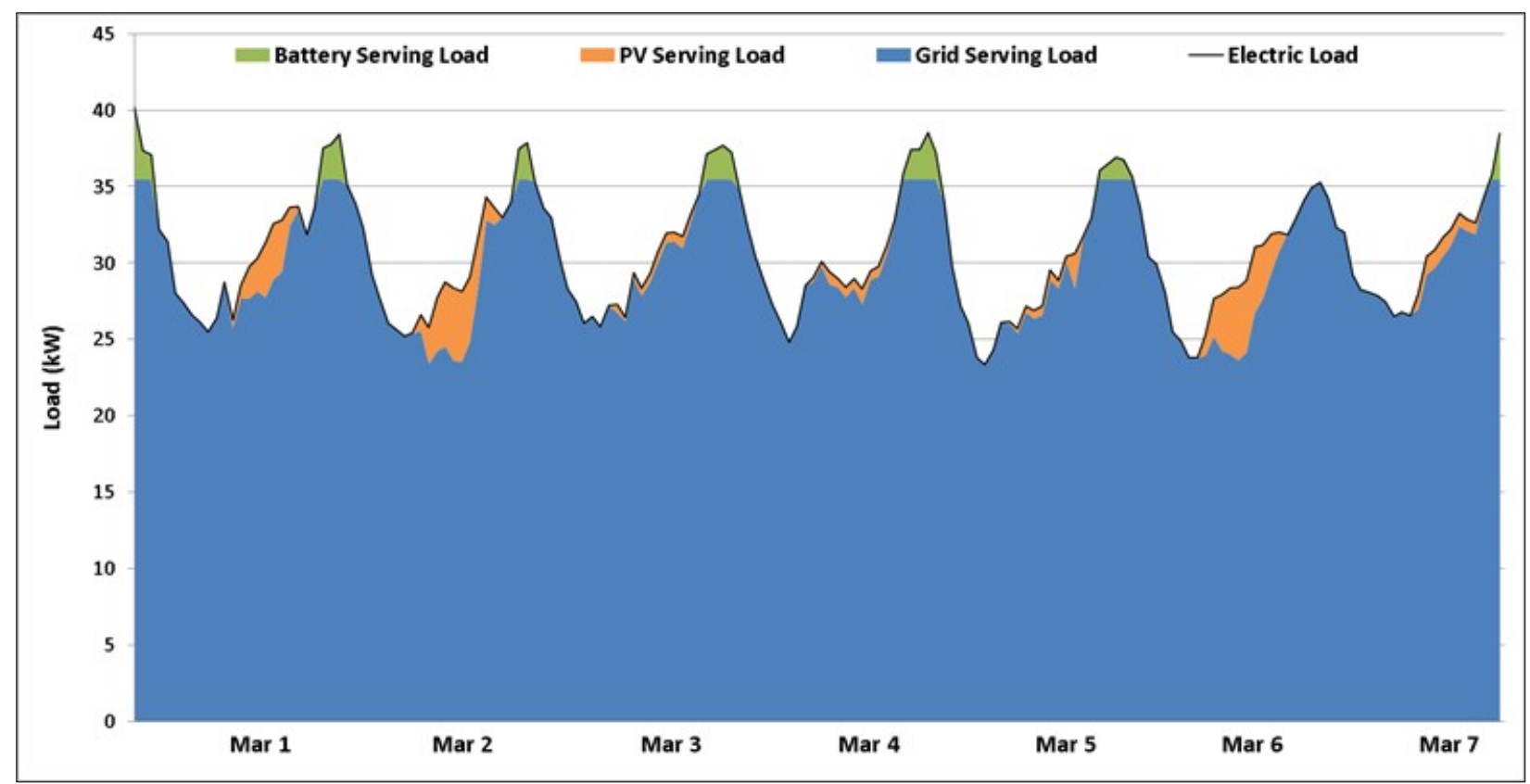

Figure 29. The battery (green) is discharged in the evening to shave the peak demand

Next, we evaluated the length of time that the PV and battery system could sustain the critical load during a short outage of 7 hours and a long outage of 51 hours. Because the PV and battery in this scenario are relatively small compared to the load, the battery cannot always sustain the full critical load. The best case outage scenarios assume that the outage starts in the evening when the air conditioners are off. In this case, the systems can power the lights, computer, fire alarm, and refrigerator through the night. However, they are too small to support the four air conditioners, which each draw $3 \mathrm{~kW}$ and together consume $12 \mathrm{~kW}$ each hour. The systems could, at most, support two air conditioners for four hours, or one air conditioner for eight hours.

Under the worst case scenario (low PV and high load), these systems do not have an inverter large enough to support the full critical load. However, they could support $31-32 \%$ of the critical load for a 7-hour outage. Under the best case scenario (high PV and low load), the systems could support additional load beyond the critical load during a 7-hour outage. During a 51-hour outage, the systems could support $13 \%$ of the critical load under the worst case scenario and $20-22 \%$ under the best case scenario; see Table 25. 
Table 25. Percent of Critical Load System Can Support

\begin{tabular}{|l|l|l|l|}
\hline & $\begin{array}{l}\text { System 1.1: No } \\
\text { resiliency value } \\
\text { captured }\end{array}$ & $\begin{array}{l}\text { System 1.2: Short- } \\
\text { duration resiliency } \\
\text { value captured }\end{array}$ & $\begin{array}{l}\text { System 1.3: Long- } \\
\text { duration resiliency } \\
\text { value captured }\end{array}$ \\
\hline 7-Hour Outage (Worst) & $31 \%$ & $32 \%$ & $32 \%$ \\
\hline $\mathbf{7 2 - H o u r ~ O u t a g e ~ ( B e s t ) ~}$ & $2996 \%$ & $3138 \%$ & $5138 \%$ \\
\hline $\begin{array}{l}\mathbf{5 1 - H o u r ~ O u t a g e} \\
\text { (Worst) }\end{array}$ & $13 \%$ & $13 \%$ & $26 \%$ \\
\hline $\mathbf{5 1 - H o u r ~ O u t a g e ~ ( B e s t ) ~}$ & $20 \%$ & $22 \%$ & $22 \%$ \\
\hline
\end{tabular}

\section{Scenario 2: Resilient PV Sized to meet Resiliency Needs}

A high-level summary of system sizing and costs for Scenario 2 are below in Table 26.

Table 26. Cooling Center Scenario 2 Results

\begin{tabular}{|l|l|l|l|r|}
\hline \multicolumn{7}{|c|}{ Cooling Center } \\
\hline & $\begin{array}{l}\text { System 2.1A: } \\
\text { Short outage; } \\
\text { resiliency not } \\
\text { valued }\end{array}$ & $\begin{array}{l}\text { System 2.1B: } \\
\text { Short outage; } \\
\text { resiliency } \\
\text { valued }\end{array}$ & $\begin{array}{l}\text { System 2.2A: } \\
\text { Long outage; } \\
\text { resiliency not } \\
\text { valued }\end{array}$ & $\begin{array}{l}\text { System 2.2B: } \\
\text { Long outage; } \\
\text { resiliency } \\
\text { valued }\end{array}$ \\
\hline PV Size (kW-DC) & 2 & 2 & 9 & 230 \\
\hline Battery Size (kWh) & 104 & 104 & 12 & 12 \\
\hline Battery Size (kW) & 12 & 12 & $\$ 167,006$ & $\$ 167,006$ \\
\hline Total Capital Cost & $\$ 74,907$ & $\$ 74,907$ & $-\$ 181,636$ & $-\$ 153,244$ \\
\hline NPV & $-\$ 45,555$ & $-\$ 41,516$ & 230 & 20.4 \\
\hline $\begin{array}{l}\text { Simple Payback } \\
\text { (years) }\end{array}$ & 14.9 & 14.3 & 25.5 & 9 \\
\hline
\end{tabular}

None of the systems in Scenario 2 are cost-effective. This site has a relatively high cost of PV and a low value of resiliency. The larger systems required to sustain the longer network outages cannot capture enough savings to cover their higher capital cost.

The battery size remains consistent at $12 \mathrm{~kW}$ for all four systems because the peak critical load at this site is $12 \mathrm{~kW}$. Battery capacity varies across the four systems, with much more battery storage required for the long outage. The large battery is required because the PV system can only supply about $36 \mathrm{kWh}$ of the $124 \mathrm{kWh}$ of energy required each day (29\%). Therefore, the battery has to provide most of the energy required (see Figure 30 ). 


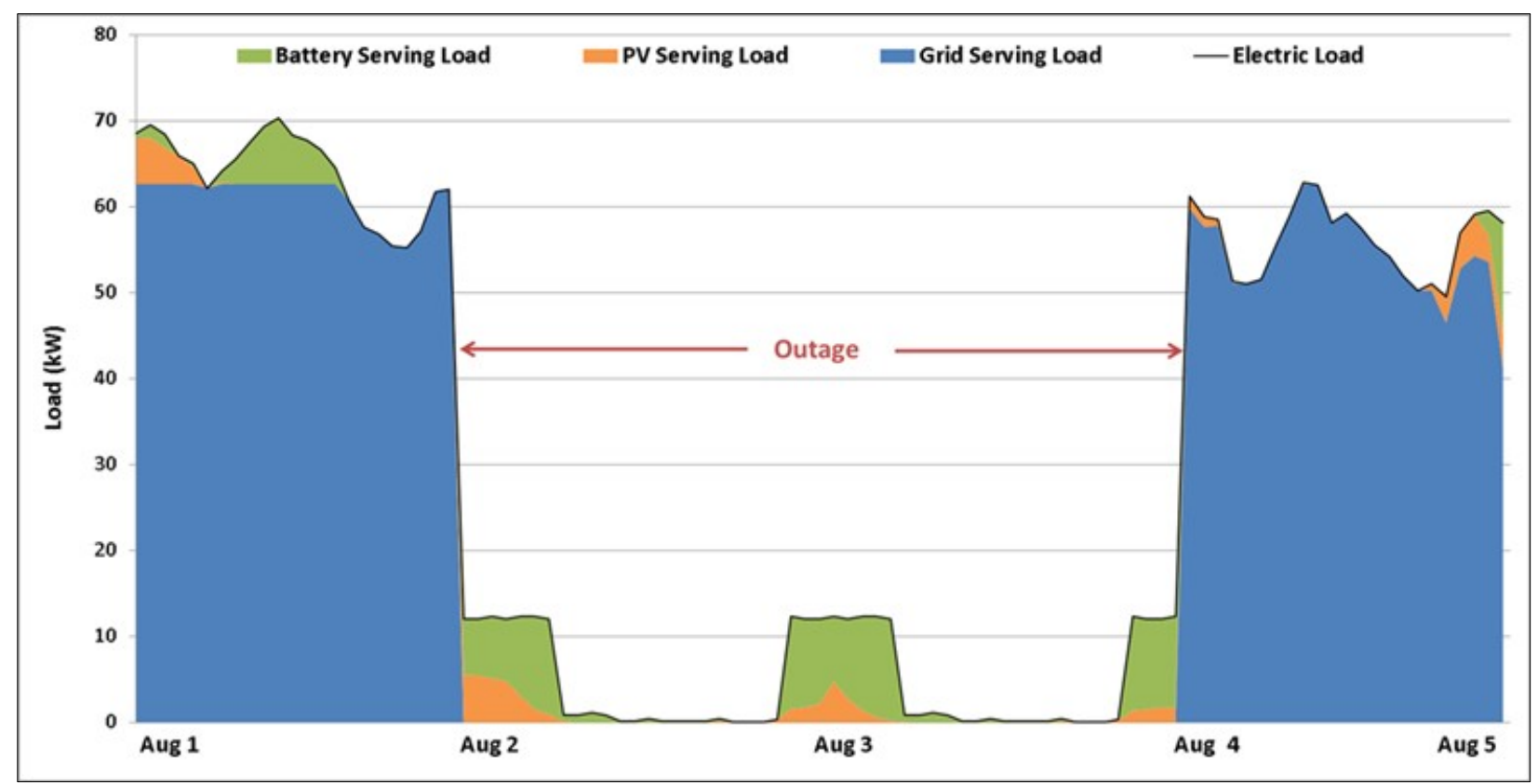

Figure 30. During a 51-hour grid outage in August, PV production is marginal and the battery (green) sustains most of the critical load

\section{Scenario 3: Resilient PV and a Generator (Hybrid System) Sized to meet Resiliency Needs}

A high-level summary of system sizing and costs for Scenario 3 are below in Table 27.

Table 27. Cooling Center Scenario 3 Results

\begin{tabular}{|c|c|c|c|c|}
\hline \multicolumn{5}{|c|}{ Cooling Center } \\
\hline \multicolumn{5}{|c|}{ Scenario 3: PV+Storage+Generator Sized to Meet Resiliency Needs } \\
\hline & $\begin{array}{l}\text { System 3.1A: } \\
\text { Short outage; } \\
\text { resiliency not } \\
\text { valued }\end{array}$ & $\begin{array}{l}\text { System 3.1B: } \\
\text { Short outage; } \\
\text { resiliency } \\
\text { valued } \\
\end{array}$ & $\begin{array}{l}\text { System } 3.2 A \text { : } \\
\text { Long outage; } \\
\text { resiliency not } \\
\text { valued } \\
\end{array}$ & $\begin{array}{l}\text { System 3.2B: } \\
\text { Long outage; } \\
\text { resiliency valued }\end{array}$ \\
\hline PV Size (kW-DC) & 0 & 2 & 0 & 9 \\
\hline Battery Size (kWh) & 25 & 28 & 25 & 35 \\
\hline Battery Size (kW) & 7 & 7 & 7 & 8 \\
\hline $\begin{array}{l}\text { Diesel Generator } \\
\text { Size (kW) }\end{array}$ & 9 & 9 & 10 & 7 \\
\hline $\begin{array}{l}\text { Diesel Fuel Used } \\
\text { (gallons/yr) }\end{array}$ & 8 & 7 & 41 & 30 \\
\hline Total Capital Cost & $\$ 33,798$ & $\$ 42,261$ & $\$ 34,376$ & $\$ 70,893$ \\
\hline NPV & $\$ 430$ & $\$ 0$ & $\$ 1,008$ & $\$ 9,329$ \\
\hline $\begin{array}{l}\text { Simple Payback } \\
\text { (years) }\end{array}$ & 11.4 & 12.2 & 11.3 & 12.3 \\
\hline
\end{tabular}


All of the systems in scenario 3 were cost-effective. Solar is only cost-effective when a resiliency value is included. Adding in a resiliency value stream allows for the addition of a small PV system in System 3.1B and a larger PV system in 3.2B. It also increases the NPV by $\$ 8,000$ for a long outage.

The PV and battery are synergistic, and adding a larger PV system results in a larger battery. Adding solar in System 3.2.B reduces diesel fuel use by $25 \%$ during the long duration outage, compared to the battery-generator system in System 3.2.A.

The battery provides demand savings during normal grid-tied operation and also sustains part of the critical load during the outage to reduce the size of diesel generator required and reduce runtime of the diesel generator; see Figure 31. In summary, the hybrid scenario consistently outperforms scenario 2 and 4 in economics, while achieving the desired resiliency for both short and long duration.

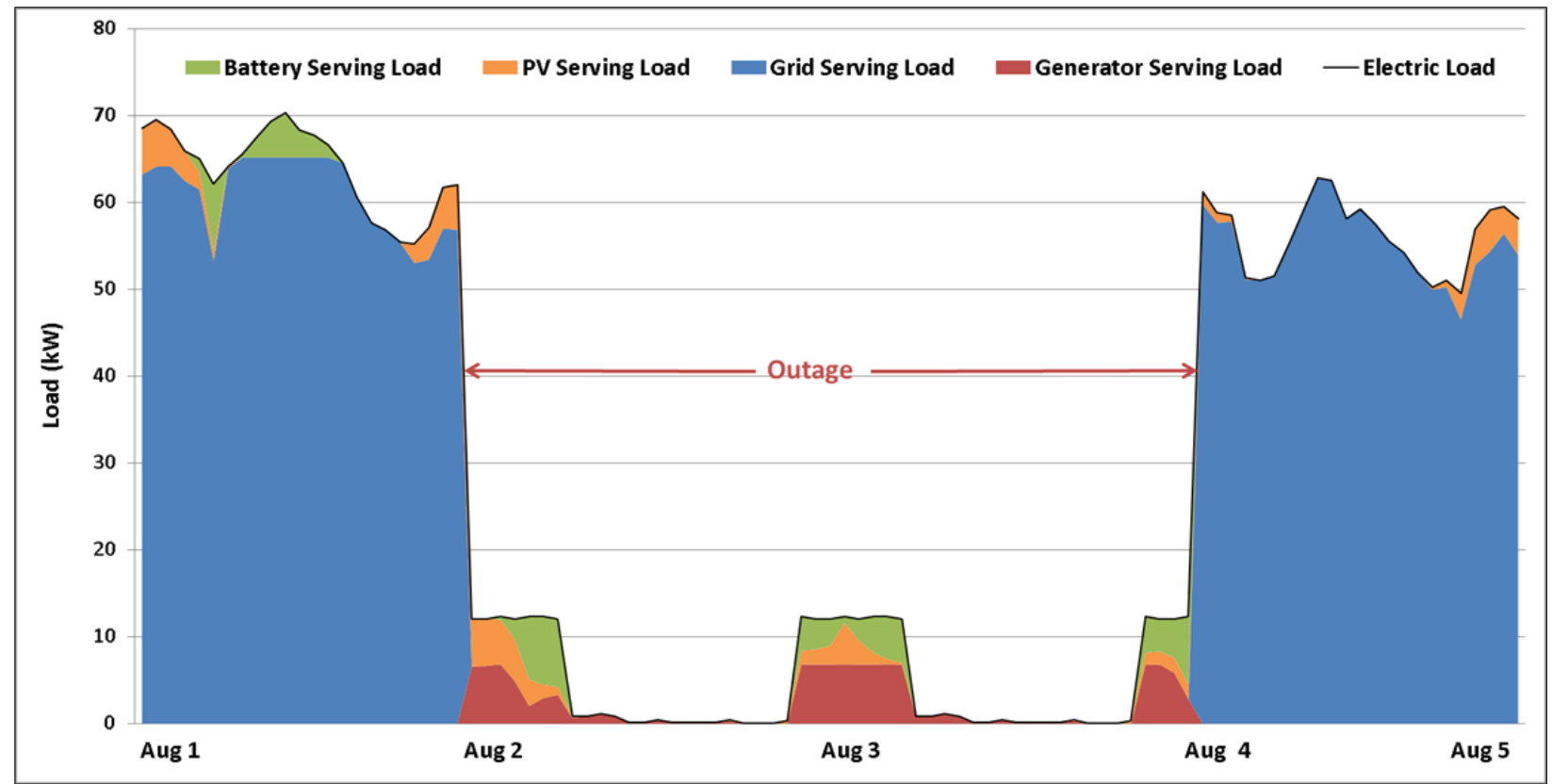

Figure 31. During the 51-hour outage in August, the PV and battery reduce the size of diesel generator required to meet the critical load, as well as reducing run-time of the diesel generator

Scenario 4: Generator Sized to meet Resiliency Needs

A high-level summary of system sizing and costs for Scenario 4 are below in Table 28. 
Table 28. Cooling Center Scenario 4 Results

\begin{tabular}{|l|r|r|r|r|}
\hline \multicolumn{5}{|c|}{ Cooling Center } \\
\hline \multicolumn{5}{|c|}{ Scenario 4: Generator Sized to Meet Resiliency Needs } \\
\hline & $\begin{array}{l}\text { System 4.1A: } \\
\text { Short outage; } \\
\text { resiliency not } \\
\text { valued }\end{array}$ & $\begin{array}{l}\text { System 4.1B: } \\
\text { Short outage; } \\
\text { resiliency } \\
\text { valued }\end{array}$ & $\begin{array}{l}\text { System 4.2A: } \\
\text { Long outage; } \\
\text { resiliency not } \\
\text { valued }\end{array}$ & $\begin{array}{l}\text { System 4.2B: } \\
\text { Long outage; } \\
\text { resiliency } \\
\text { valued }\end{array}$ \\
\hline $\begin{array}{l}\text { Diesel Generator Size } \\
\text { (kW) }\end{array}$ & 12 & 12 & 12 & 12 \\
\hline $\begin{array}{l}\text { Diesel Fuel Used } \\
\text { (gallons/yr) }\end{array}$ & 9 & 9 & 48 & 48 \\
\hline Total Capital Cost & $\$ 18,600$ & $\$ 18,600$ & $\$ 18,600$ & $\$ 18,600$ \\
\hline NPV & $-\$ 25,411$ & $-\$ 21,372$ & $-\$ 24,246$ & $\$ 2,562$ \\
\hline Simple Payback (years) & None & None & None & 11.0 \\
\hline
\end{tabular}

For comparison, we also evaluated the cost of a conventional diesel-only backup system. A diesel generator is only cost-effective in Scenario 4 for a long outage when resiliency is valued. The NPV of $\$ 2600$ is relatively low and the payback period is 11 years.

The size of the generator remains consistent across all four systems at $12 \mathrm{~kW}$, so the capital cost is the same for all four systems as well. When resiliency is not valued, the cost of a system that supports a short and long outage is equivalent, but the amount of fuel required increases from 9 to 48 gallons.

\section{Discussion of Cooling Center Results Across All Scenarios}

To compare cost-effectiveness across the systems designed primarily to support resiliency needs (Scenarios 2, 3, and 4), the NPV and payback periods are listed in Table 29. The cells highlighted in green represent the best NPV and best payback period for each column. Scenario 3 again presents the best economic system option to cover both short and long outages. 
Table 29. Cooling Center NPV and Payback Comparison of Scenarios 2, 3, and 4

\begin{tabular}{|l|r|r|r|r|}
\hline \multicolumn{5}{|c|}{ Cooling Center } \\
\hline & $\begin{array}{l}\text { Short outage; } \\
\text { resiliency not } \\
\text { valued }\end{array}$ & $\begin{array}{l}\text { Long outage; } \\
\text { resiliency not } \\
\text { valued }\end{array}$ & $\begin{array}{l}\text { Short outage; } \\
\text { resiliency } \\
\text { valued }\end{array}$ & $\begin{array}{l}\text { Long outage; } \\
\text { resiliency } \\
\text { valued }\end{array}$ \\
\hline & $-\$ 45,555$ & $-\$ 181,636$ & $-\$ 41,516$ & $-\$ 153,244$ \\
\hline $\begin{array}{l}\text { Scenario 2: PV+Storage } \\
\text { NPV }\end{array}$ & 14.9 & 25.5 & 14.3 & 20.4 \\
\hline $\begin{array}{l}\text { Scenario 2: PV+Storage } \\
\text { Payback }\end{array}$ & $\$ 430$ & $-\$ 1,008$ & $\$ 0$ & $\$ 9,329$ \\
\hline Scenario 3: Hybrid NPV & 11.4 & 11.3 & 12.2 & 12.3 \\
\hline $\begin{array}{l}\text { Scenario 3: Hybrid } \\
\text { Payback }\end{array}$ & $-\$ 25,411$ & $-\$ 24,246$ & $-\$ 21,372$ & $\$ 2,562$ \\
\hline Scenario 4: Generator NPV & N/A & N/A & N/A & 11.0 \\
\hline $\begin{array}{l}\text { Scenario 4: Generator } \\
\text { Payback }\end{array}$ & & & & \\
\hline
\end{tabular}

\section{Recommendations}

Currently, there is no established resiliency value stream; therefore, it is up to the individual facility and its larger agency to determine how resiliency is valued. The level at which resiliency is valued will influence the type of emergency power system that the facility should implement. Whether or not these three facilities assign an economic value to resiliency, if they want to deploy an emergency power system, a hybrid system (Scenario 3) is recommended. If emergency power is viewed as a secondary benefit to the economic benefits that a resilient PV system can provide, a Scenario 1 system is recommended. Scenario 1 systems will allow the host site to see a return on its investment while receiving some degree of emergency power in the event of an outage, depending on when the outage occurs. 


\section{Conclusion}

This analysis modeled resilient PV systems designed for economic savings and examined the amount of emergency power these systems are capable of providing. The analysis also modeled resilient PV and hybrid systems designed to support emergency power needs, which could then be used for economic savings during normal grid operations. Finally, the analysis looked at generator-only systems designed to support emergency power needs in order to compare this traditional resiliency solution with resilient PV and hybrid solutions. The results for these sites indicate that:

- Resilient PV and hybrid systems can be NPV-positive with and without a resiliency value stream included.

- For NYPA customers, the economics of resilient PV are better than standalone solar PV, primarily due to the battery's ability to reduce utility demand charges.

- Project economics for all modeled systems are greatly improved for radial customers when a resiliency value stream is included due to higher frequency of outages that occur on radial systems vs. network grids.

- Project economics for all modeled systems are moderately improved for network customers when a resiliency value stream is included.

- Resilient PV sized for cost savings (i.e., not for resiliency) will provide limited resiliency benefits.

- The level of resiliency provided by resilient PV systems sized for utility cost savings depends on when the outage occurs, state of charge of the battery, and load size.

- Resilient PV and hybrid systems designed to support short long outages result in systems that are larger and more costly than systems sized for cost savings.

- In some cases, inclusion of a value for avoiding utility power outages can more than offset the additional costs incurred by sizing resilient PV for resiliency rather than utility cost savings alone.

- Generators as a resiliency solution are not NPV-positive except when resiliency is valued for long outages.

- Though generators are the most widely used form of emergency and stand-by power, solarplus-storage and hybrid systems can offer the same benefits at a better lifecycle cost. However, generators have a lower initial cost.

Scenario 1 results show that a modestly sized battery system can be strategically charged and discharged such that it shaves the peak loads and, therefore, captures significant demand savings. Since the capacity of these batteries is small, they can generally only support the critical load for a few hours, much less than the five-day outage period desired by many of the onsite staff interviewed for this project. Similarly, small roof space at two of the sites offered nominal energy savings during grid operations, and extended the duration of outage that could be served by a battery by a few hours. When resiliency isn't prioritized or valued, a Scenario 1 system can support emission reduction targets and lower electricity costs. 
The results from the second scenario show that it would take a battery of considerable size and increased solar resources to sustain the critical load for an extended outage. Inclusion of a resiliency value stream can make resilient PV economically viable, but without it, the increased system size can push the NPV negative. The results from the third scenario indicate that a hybrid system is generally the more economical system configuration for sustaining outages. The battery and PV reduce the size of the diesel generator required, and the diesel generator provides the extra energy and power required during long outage periods. The savings the battery and PV provide during normal grid-connected operation make the hybrid system more economical than a diesel generator alone, as seen in the fourth scenario. However, hybrid systems are a more complex solution with a higher first cost compared to a stand-alone diesel generator.

The size of resilient PV systems that these three sites - and other critical infrastructure sites in NYC - should deploy will depend on the priorities of the site and the degree to which resiliency is or is not valued. For city-owned buildings, solar deployment for emissions reductions is a priority. Knowing that $100 \mathrm{MW}$ of solar will be installed on city buildings, it is worth noting that this analysis finds adding storage can improve project economics for NYPA customers by reducing demand charges. The incorporation of storage into NYC's solar deployment goals will add resiliency benefits that standalone solar can not otherwise provide. Adding storage to city solar deployments could also be an opportunity to align the city's sustainability and resiliency goals.

For critical infrastructure, interest in resilient PV may be driven by resiliency benefits rather than emissions reductions. Following Hurricane Sandy, the Mayor's generator and boiler task force deemed restoring power to NYCHA's 80,000 affected residents was the next-highest priority after meeting immediate life safety needs. Rather than relying solely on generators to supply emergency power needs, hybrid systems can offer NYCHA (and other sites) an option that is more cost-effective and reduces reliance on a single technology. Regulatory changes may be necessary in order to permit resilient PV as a code-compliant option for emergency power, similar to how Local Law 111 removed barriers to the use of natural gas generators for emergency power. ${ }^{53}$ In addition to resiliency, cost savings are a priority across critical infrastructure. Unlike commercial buildings that generally require quick payback, public facilities may invest in solutions that offer long-term savings when upfront capital or third-party financing is available.

For commercial buildings on Con Edison's SC 9 tariff, demand charges range from \$26 $\$ 31 / \mathrm{kW}$, which is slightly lower than the demand charges for the NYPA customers modeled in this analysis (13\% - 50\% lower depending on the site and season). However, energy rates for SC 9 customers average around $\$ 0.085 / \mathrm{kWh}$ while NYPA customers average around half that at $\$ 0.044 / \mathrm{kWh}$. If the sites used in this study were analyzed on Con Edison rates, it is expected that the resulting recommended systems would have smaller battery systems, and larger PV systems. The facilities that are space-constrained would likely see all available space used for solar, and smaller storage systems. Improved project economics for a Con Edison customer would be more likely at a location with ample roof space for solar.

\footnotetext{
${ }^{53}$ Building Resiliency Task Force, 2016. "Remove Barriers to Backup \& Natural Gas Generators." Urban Green Council. http://urbangreencouncil.org/content/remove-barriers-backup-natural-gas-generators.
} 
Overall, results of this analysis show that pairing these systems with storage (and generators when resiliency is a priority) may be economical depending on payback requirements, site suitability, and other factors. As a next step, obtaining more granular cost assumption data on resilient PV projects would help fill in any gaps on integration, critical load isolation, and other additional costs. Improved cost assumptions would yield more accurate estimates to inform investment decisions, but these are difficult to obtain in a young market. However, as the solar and storage markets mature and prices decline, and as utilities adopt rates that are more advantageous to distributed generation ${ }^{54}$, project economics will also improve for both NYPA and Con Edison customers. The question of how resiliency is valued for critical infrastructure also needs to be answered in order to truly understand the economics of emergency power investments.

In order to start a conversation about the value of resiliency, this analysis presents a potential resiliency value in order to compare results to systems that do not value resiliency. These values do not capture the full complexity of valuing resiliency. For example, power outages have real costs which are often borne by federal agencies that are less involved in local resiliency investments. The Federal Emergency Management Agency (FEMA) typically covers $75 \%$ or more of recovery costs when a local event is declared a national disaster. How to value resiliency will require local, state, and national conversations with the public, government agencies, and private companies that bear the brunt of outage costs.

${ }^{54}$ This is expected under New York State's Reforming the Energy Vision. 


\section{Appendix A. Critical Load Calculations}

Table A-1. NYCHA Cooling Center Daily Critical Load During the Summer

\begin{tabular}{|c|c|c|c|c|c|c|c|}
\hline Equipment & Quantity & Power (W) & Total (W) & $\begin{array}{l}\text { Day hours } \\
(7: 00-5: 00)\end{array}$ & $\begin{array}{c}\text { Evening } \\
(6: 00-10: 00)\end{array}$ & $\begin{array}{c}\text { Night } \\
(11: 00-6: 00)\end{array}$ & $\begin{array}{c}\text { Total } \\
\text { (kWh/day) }\end{array}$ \\
\hline Air conditioner & 4 & 3000 & 12000 & 8 & & & 96 \\
\hline Desktop computer & 1 & 230 & 230 & 2 & 1 & & 0.69 \\
\hline Tube-Fluorescents (T-8) & 10 & 32 & 320 & & 4 & & 1.28 \\
\hline CFL & 3 & 16 & 48 & & & 8 & 0.38 \\
\hline Refrigerator & 1 & 300 & 300 & 2 & 2 & 1 & 1.50 \\
\hline Total & & & & 97.11 & 2.11 & 0.68 & 99.85 \\
\hline
\end{tabular}


Table A-2. NYC-DOE School Shelter Daily Critical Load During the Summer and Winter

\begin{tabular}{|c|c|c|c|c|c|c|c|c|c|}
\hline & & \multicolumn{4}{|c|}{ Summer } & \multicolumn{4}{|c|}{ Winter } \\
\hline & & \multicolumn{4}{|c|}{ Hours used per day } & \multicolumn{4}{|c|}{ Hours used per day } \\
\hline Room Equipment & $\begin{array}{c}\text { Total } \\
\text { (W) }\end{array}$ & $\begin{array}{c}\text { Day } \\
\text { (7am-5pm) }\end{array}$ & $\begin{array}{c}\text { Evening } \\
(6 \mathrm{pm}-10 \mathrm{pm})\end{array}$ & $\begin{array}{c}\text { Night } \\
\text { (10pm-6am) }\end{array}$ & $\begin{array}{c}\text { Total } \\
\text { kWh/da } \\
y\end{array}$ & $\begin{array}{c}\text { Day } \\
\text { (7am-5pm) }\end{array}$ & $\begin{array}{c}\text { Evening } \\
\text { (6pm- } \\
10 \mathrm{pm})\end{array}$ & $\begin{array}{c}\text { Night } \\
\text { (10pm-6am) }\end{array}$ & $\begin{array}{c}\text { Total } \\
\text { kWh/day }\end{array}$ \\
\hline Window AC units & 6000 & 9 & 3 & 0 & 72 & 0 & 0 & 0 & 0 \\
\hline Desktop computer & 460 & 4 & 0 & 0 & 2 & 4 & 0 & 0 & 2 \\
\hline LED lamps & 2016 & 10 & 4 & 0 & 28 & 10 & 4 & 0 & 28 \\
\hline Tube-Fluorescents (T-8) & 4544 & 10 & 4 & 0 & 64 & 10 & 4 & 0 & 64 \\
\hline Electrical outlets & 48 & 10 & 4 & 0 & 1 & 10 & 4 & 0 & 1 \\
\hline \multicolumn{10}{|l|}{ Boiler Room Equipment } \\
\hline Fuel oil pump & 1167 & 4 & 4 & & 9 & 10 & 4 & 8 & 26 \\
\hline Vacuum pump & 2691 & 4 & 4 & & 22 & 10 & 4 & 8 & 59 \\
\hline Feed water pump & 2725 & 4 & 4 & & 22 & 10 & 4 & 8 & 60 \\
\hline Condensate pump & 4248 & 4 & 4 & & 34 & 10 & 4 & 8 & 93 \\
\hline Sewage ejector pump & 2691 & 1 & & & 3 & 1 & & & 3 \\
\hline air compressors & 4021 & 2 & & & 8 & 2 & & & 8 \\
\hline Sump pump & 2043 & 3 & 2 & 3 & 16 & 3 & 2 & 3 & 16 \\
\hline Freezer (Walk-in) & 3664 & 8 & 4 & 4 & 59 & 8 & 4 & 4 & 59 \\
\hline Refrigerator (Walk-in) & 2774 & 2 & 1 & 2 & 14 & 2 & 1 & 2 & 14 \\
\hline Totals & & & & & 352.57 & & & & 432.20 \\
\hline
\end{tabular}




\section{Appendix B. Resiliency Calculations}

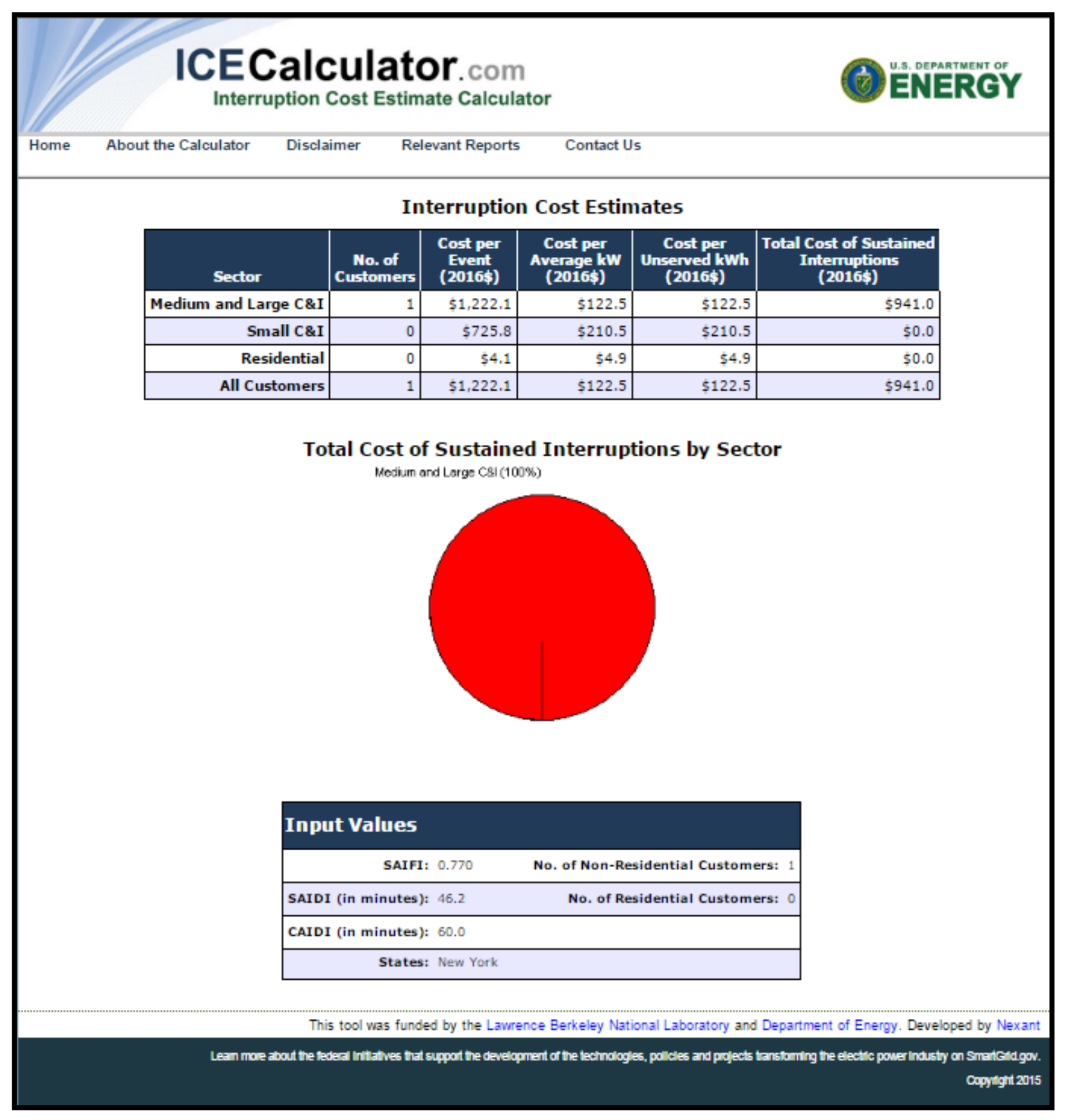

Figure B-1. Outputs from the ICE Calculator for the Fire Station 
Table B-1. Outputs from the ICE Calculator for 1-16 Hour Outages (in 60-Minute Increments) for the Fire Station

\begin{tabular}{|c|c|cc|cr|}
\hline \multicolumn{7}{|c|}{ Fire Station Outage Cost Curve (radial customer) } \\
\hline \multicolumn{2}{|c|}{ CAIDI I } & \multicolumn{2}{c|}{ Cost } & \multicolumn{2}{l|}{ Unit Cost } \\
\hline Hours & Minutes & \multicolumn{2}{c|}{ Interruption Cost } & \multicolumn{2}{l|}{ Cost of Interruption } \\
\hline 1 & 60 & $\$$ & 941 & $\$$ & 941.00 \\
\hline 2 & 120 & $\$$ & 1,447 & $\$$ & 723.70 \\
\hline 3 & 180 & $\$$ & 2,110 & $\$$ & 703.30 \\
\hline 4 & 240 & $\$$ & 2,935 & $\$$ & 733.70 \\
\hline 5 & 300 & $\$$ & 3,918 & $\$$ & 783.64 \\
\hline 6 & 360 & $\$$ & 5,044 & $\$$ & 840.70 \\
\hline 7 & 420 & $\$$ & 6,287 & $\$$ & 898.09 \\
\hline 8 & 480 & $\$$ & 7,608 & $\$$ & 951.04 \\
\hline 9 & 540 & $\$$ & 8,963 & $\$$ & 995.89 \\
\hline 10 & 600 & $\$$ & 10,298 & $\$$ & $1,029.77$ \\
\hline 11 & 660 & $\$$ & 11,554 & $\$$ & $1,050.38$ \\
\hline 12 & 720 & $\$$ & 12,674 & $\$$ & $1,056.17$ \\
\hline 13 & 780 & $\$$ & 13,601 & $\$$ & $1,046.24$ \\
\hline 14 & 840 & $\$$ & 14,287 & $\$$ & $1,020.52$ \\
\hline 15 & 900 & $\$$ & 14,695 & $\$$ & 979.67 \\
\hline 16 & 960 & $\$$ & 14,801 & $\$$ & 925.06 \\
\hline Average & & & & $\$$ & 917.43 \\
\hline & & & & & \\
\hline
\end{tabular}

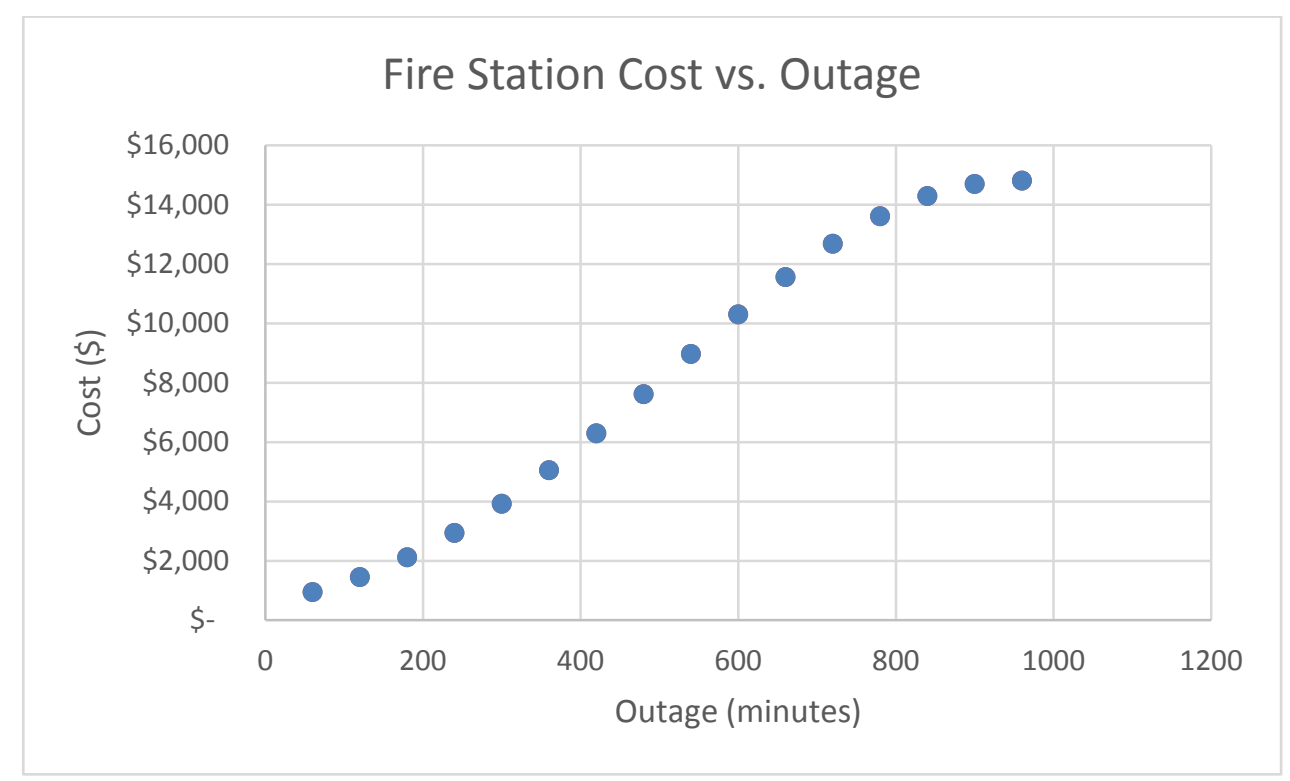

Figure B-2. Cost vs. Outage Length from the ICE Calculator for the Fire Station 


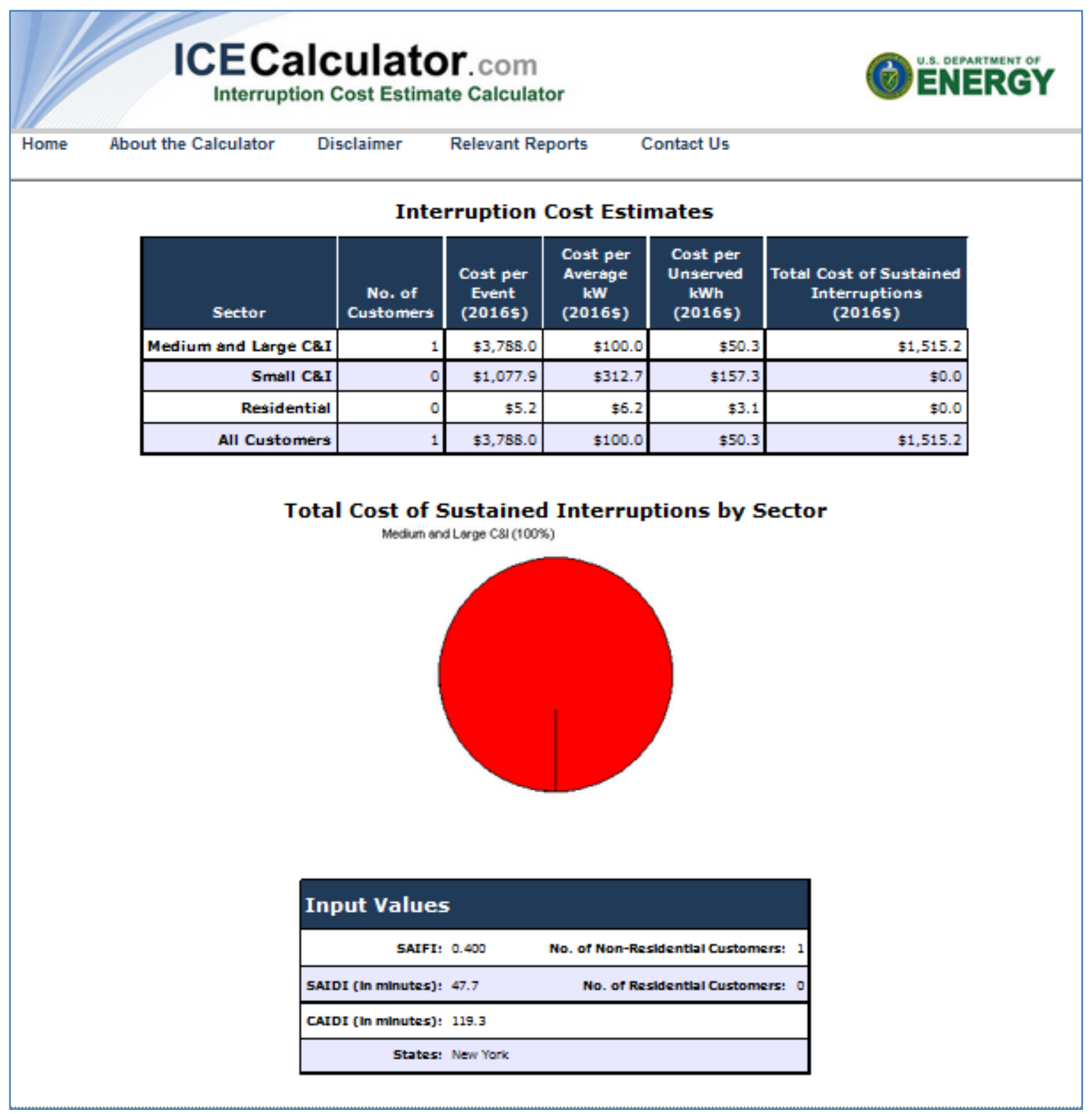

Figure B-3. Outputs from the ICE Calculator for the NYCHA Cooling Center 
Table B-2. Outputs from the ICE Calculator for 1-16 Hour Outages (in 60-Minute Increments) for the Cooling Center

\begin{tabular}{|c|c|c|c|}
\hline \multicolumn{4}{|c|}{ NYCHA Cooling Center Outage Cost Curve (network customer) } \\
\hline \multicolumn{2}{|c|}{ CAIDI } & \multirow{2}{*}{$\frac{\text { Cost }}{\text { Interruption Cost }}$} & \multirow{2}{*}{$\begin{array}{l}\text { Unit Cost } \\
\text { Cost of Interruption }\end{array}$} \\
\hline Hours & Minutes & & \\
\hline 1 & 60 & $\$ 30$ & $\$ 29.70$ \\
\hline 2 & 120 & $\$ 47$ & $\$ 23.60$ \\
\hline 3 & 180 & $\$ 71$ & $\$ 23.53$ \\
\hline 4 & 240 & $\$ 100$ & $\$ 25.03$ \\
\hline 5 & 300 & $\$ 136$ & $\$ 27.12$ \\
\hline 6 & 360 & $\$ 177$ & $\$ 29.43$ \\
\hline 7 & 420 & $\$ 222$ & $\$ 31.69$ \\
\hline 8 & 480 & $\$ 270$ & $\$ 33.75$ \\
\hline 9 & 540 & $\$ 319$ & $\$ 35.48$ \\
\hline 10 & 600 & $\$ 368$ & $\$ 36.76$ \\
\hline 11 & 660 & $\$ 413$ & $\$ 37.53$ \\
\hline 12 & 720 & $\$ 453$ & $\$ 37.73$ \\
\hline 13 & 780 & $\$ 485$ & $\$ 37.32$ \\
\hline 14 & 840 & $\$ 508$ & $\$ 36.31$ \\
\hline 15 & 900 & $\$ 521$ & $\$ 34.74$ \\
\hline 16 & 960 & $\$ 523$ & $\$ 32.67$ \\
\hline Average & & & $\$ 32.02$ \\
\hline
\end{tabular}

\section{Cost vs Outage}

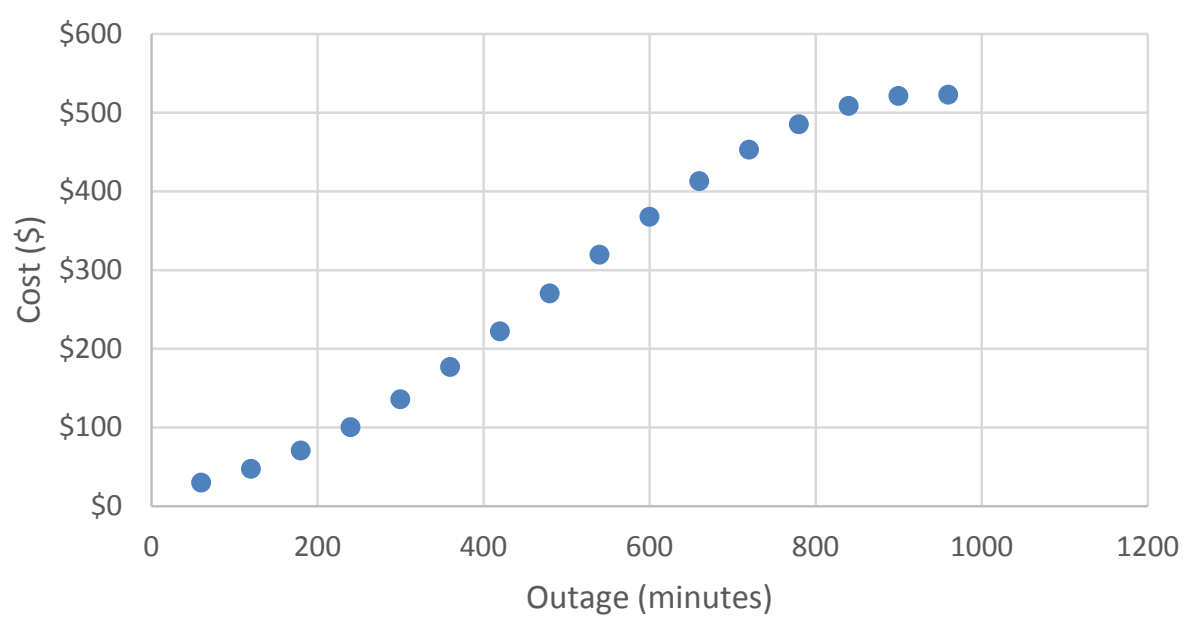

Figure B-4. Cost vs. Outage Length from the ICE Calculator for the Cooling Center 


\section{ICECalculator.com}

Interruption Cost Estimate Calculator

Home About the Calculator Disclaimer Relevant Reports Contact Us

Interruption Cost Estimates

\begin{tabular}{|c|c|c|c|c|c|}
\hline Sector & $\begin{array}{c}\text { No. of } \\
\text { Customers }\end{array}$ & $\begin{array}{l}\text { Cost per } \\
\text { Event } \\
\text { (2016\$) }\end{array}$ & $\begin{array}{l}\text { Cost per } \\
\text { Average kW } \\
\text { (2016\$) }\end{array}$ & $\begin{array}{c}\text { Cost per } \\
\text { Unserved kWh } \\
\text { (2016\$) }\end{array}$ & $\begin{array}{l}\text { Total Cost of Sustained } \\
\text { Interruptions } \\
\text { (2016\$) }\end{array}$ \\
\hline Medium and Large C\&I & 1 & $\$ 1,931.8$ & $\$ 86.0$ & $\$ 86.0$ & $\$ 77.3$ \\
\hline Small C\&I & 0 & $\$ 725.8$ & $\$ 210.5$ & $\$ 210.5$ & $\$ 0.0$ \\
\hline Residential & 0 & $\$ 4.1$ & $\$ 4.9$ & $\$ 4.9$ & $\$ 0.0$ \\
\hline All Customers & 1 & $\$ 1,931.8$ & $\$ 86.0$ & $\$ 86.0$ & $\$ 77.3$ \\
\hline
\end{tabular}

Total Cost of Sustained Interruptions by Sector Mediun and Large Csi (100\%)

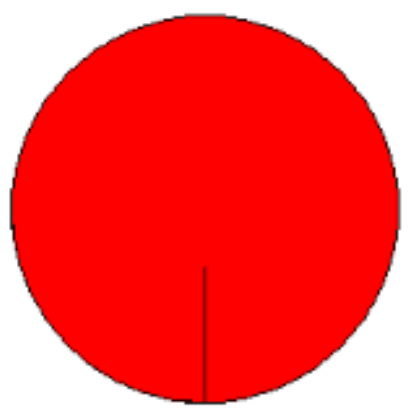

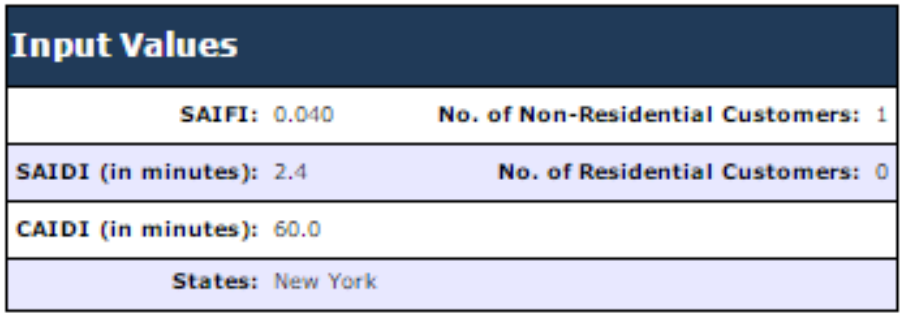

This tool was funded by the Lawrence Berkeley National Laboratory and Department of Energy. Developed by Nexant

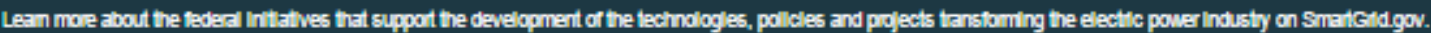

Figure B-5. Outputs from the ICE Calculator for the School Shelter 
Table B-3. Outputs from the ICE Calculator for 1-16 Hour Outages (in 60-Minute Increments) for the School Shelter

\begin{tabular}{|c|c|cc|ll|}
\hline \multicolumn{6}{|l|}{ School Shelter Outage Cost Curve (network customer) } \\
\hline \multicolumn{2}{|c|}{ CAIDI } & \multicolumn{2}{c|}{ Cost } & Unit Cost \\
\hline Hours & Minutes & \multicolumn{1}{c|}{ Interruption Cost } & Cost of Interruption \\
\hline 1 & 60 & $\$$ & 77 & $\$$ & 77.30 \\
\hline 2 & 120 & $\$$ & 116 & $\$$ & 57.75 \\
\hline 3 & 180 & $\$$ & 165 & $\$$ & 54.90 \\
\hline 4 & 240 & $\$$ & 225 & $\$$ & 56.30 \\
\hline 5 & 300 & $\$$ & 297 & $\$$ & 59.34 \\
\hline 6 & 360 & $\$$ & 378 & $\$$ & 63.02 \\
\hline 7 & 420 & $\$$ & 468 & $\$$ & 66.83 \\
\hline 8 & 480 & $\$$ & 563 & $\$$ & 70.39 \\
\hline 9 & 540 & $\$$ & 661 & $\$$ & 73.44 \\
\hline 10 & 600 & $\$$ & 758 & $\$$ & 75.78 \\
\hline 11 & 660 & $\$$ & 850 & $\$$ & 77.23 \\
\hline 12 & 720 & $\$$ & 932 & $\$$ & 77.68 \\
\hline 13 & 780 & $\$$ & 1,002 & $\$$ & 77.04 \\
\hline 14 & 840 & $\$$ & 1,054 & $\$$ & 75.31 \\
\hline 15 & 900 & $\$$ & 1,088 & $\$$ & 72.52 \\
\hline 16 & 960 & $\$$ & 1,100 & $\$$ & 68.74 \\
\hline Average & & & & $\$$ & 68.97 \\
\hline & & & & & \\
\hline
\end{tabular}

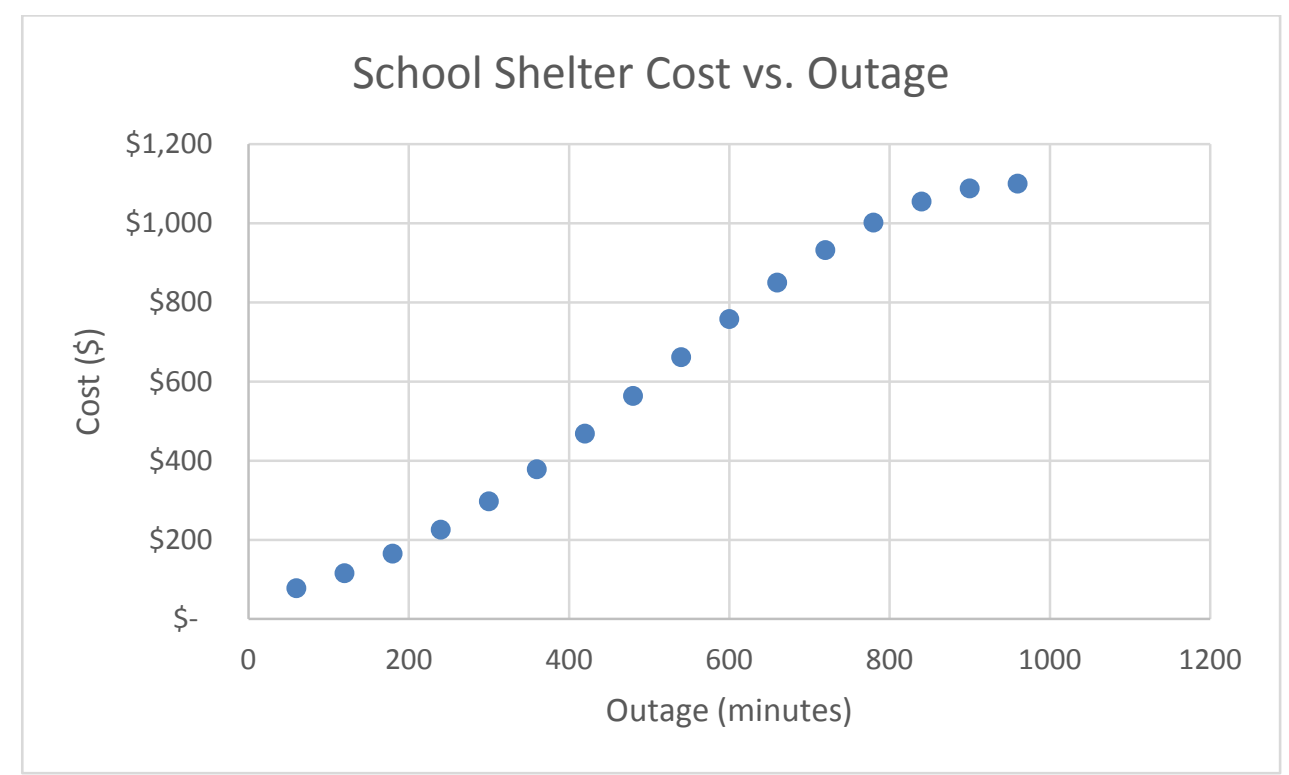

Figure B-6. Cost vs. Outage Length from the ICE Calculator for the School Shelter 


\title{
Appendix C. Utility Rate Tariffs
}

\author{
New York Power Authority \\ First Revised Service Tariff No. 100

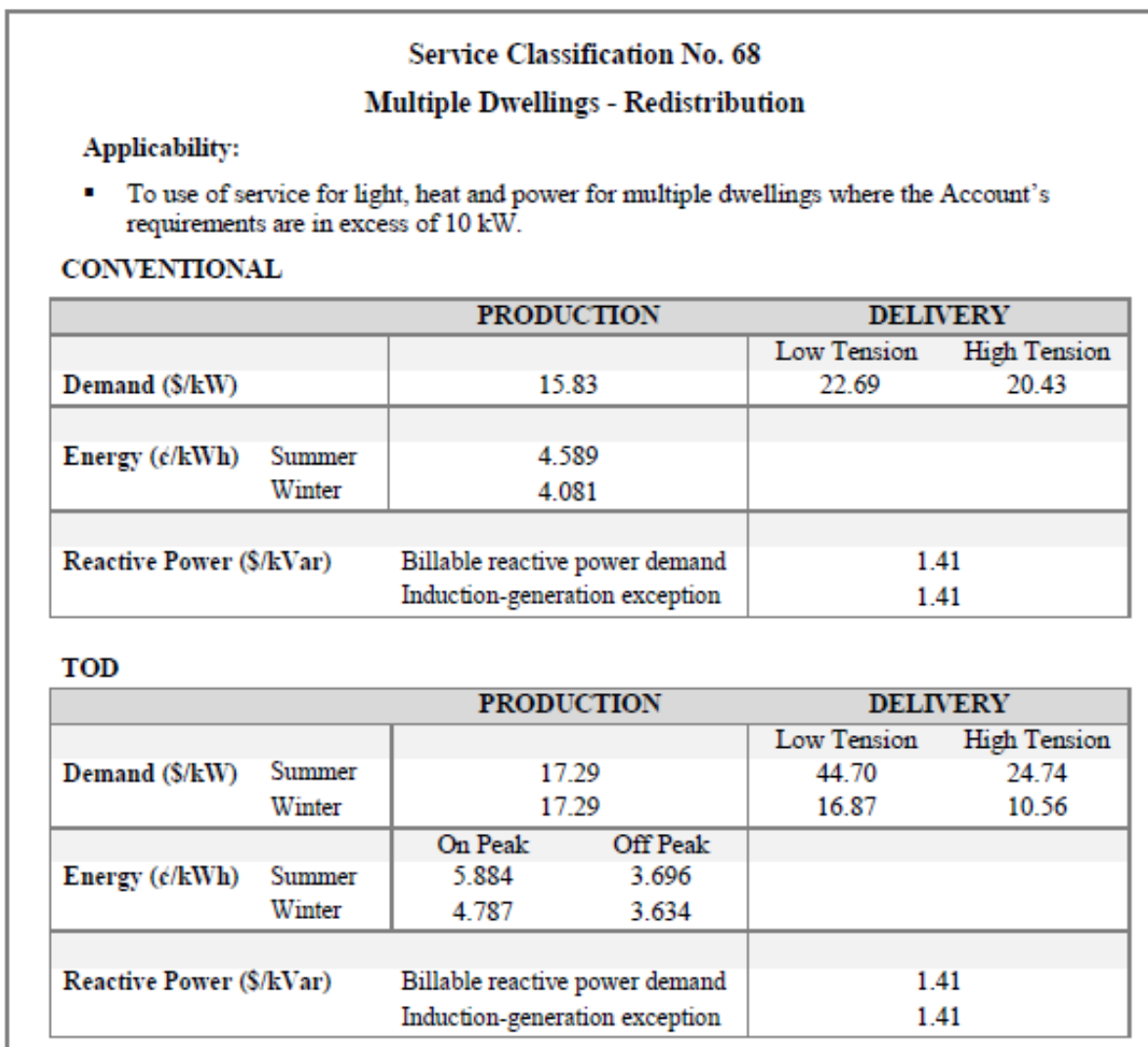

Time Period Conventional:

- All hours, all days

Time Period TOD:

- Demand Charge:

On-Peak: 8:00 a.m. to 6:00 p.m. weekdays (including holidays)

Off-Peak: All other times

- Energy Charge:

On-Peak: $8: 00 \mathrm{a} . \mathrm{m}$ to $10 \mathrm{p} . \mathrm{m}$. weekdays (including holidays)

Off-Peak: All other times

(SC 68 - Continued on Leaf No. 17)

Date of Issue: March 26, 2015

Date Effective: March 2015 Bill Period

Modified to be consistent with Con Edison PSC No. 12, Case 13-E-0030

Is sued by James F. Pasquale, Senior Vice President

Power Authority of the State of New York

30 South Pearl Street, Albany, NY 12207

Figure C-1. Service Classification No. 68 


\section{Service Classification No. 91 \\ New York City Public Buildings}

Applicability:

- To use of service for light, heat and power for the City of New York's public buildings, offices and structures, or parts thereof, used by the City of New York for public purposes.

CONVENTIONAL

\begin{tabular}{|ll|c|c|}
\hline \multicolumn{2}{|c}{ PRODUCTION } & \multicolumn{2}{c|}{ DELIVERY } \\
\hline \multirow{2}{*}{ Demand (\$/kW) } & & 22.69 & High Tension \\
\hline \multirow{2}{*}{ Energy (c/kWh) } & Summer & 4.84 & \\
& Winter & 4.335 & \\
\hline \multirow{2}{*}{ Reactive Power (\$/kVar) } & Billable reactive power demand & 1.41 \\
& Induction-generation exception & 1.41 \\
\hline
\end{tabular}

TOD

\begin{tabular}{|c|c|c|c|c|c|}
\hline & & PRO & IION & DEI & ERY \\
\hline & & & & Low Tension & High Tension \\
\hline Demand $(\$ / k W)$ & Summer & & & 44.70 & 24.74 \\
\hline & Winter & & & 16.87 & 10.56 \\
\hline & & On Peak & Off Peak & & \\
\hline Energy (c/kWh) & Summer & 5.940 & 3.752 & & \\
\hline & Winter & 4.843 & 3.690 & & \\
\hline Reactive Power ( & (kVar) & Billable reac & wer demand & & \\
\hline & & Induction-ge & n exception & & \\
\hline
\end{tabular}

\section{UNMETERED FIRE ALARM AND SIGNAL SYSTEMS}

- For the operation of interior fire alarm or signal systems not connected to the metered supply for the building and where separate service is supplied

\begin{tabular}{|lcc|}
\hline For service connection & (\$ per month) & 119.79 \\
\hline $\begin{array}{l}\text { For each gong or signal circuit or combination of gong or signal } \\
\text { circuits, in which there is a continuous flow of current of not over }\end{array}$ & & \\
$\begin{array}{l}125 \text { milliamperes, the voltage of the supply being approximately } \\
120 \text { volts or the equivalent (taken as 15 volt-amperes) at other }\end{array}$ & & \\
$\begin{array}{l}\text { supply voltages } \\
\text { For each additional 125 milliamperes (or equivalent) of } \\
\text { continuous flow, or traction thereof, an additional charge of }\end{array}$ & (\$ per month) & 8.23 \\
\hline
\end{tabular}

(SC 91 - Continued on Leaf No. 28) 


\section{Appendix D. Additional Results}

NYC-DOE

Table D-1. School Shelter Baseline: No Resilient PV

\begin{tabular}{|c|c|c|c|}
\hline Scenario Number & 0.1 & 0.2 & 0.3 \\
\hline Description & $\begin{array}{l}\text { Without cost of grid } \\
\text { interruptions }\end{array}$ & $\begin{array}{l}\text { With cost of } 2 \\
\text { hours/year grid } \\
\text { interruptions }\end{array}$ & $\begin{array}{c}\text { With cost of } 22 \\
\text { hours/year grid } \\
\text { interruptions }\end{array}$ \\
\hline Outage START (hour of year) & - & - & - \\
\hline Outage STOP (hour of year) & - & - & - \\
\hline Resiliency Value (\$/hour) & 0 & $68.97,7.25$ hours & $68.97,50.96$ hours \\
\hline Outage Duration (hours) & 0 & 0 & 0 \\
\hline PV Size (kW-DC) & 0 & 0 & 0 \\
\hline Battery Size (kWh) & 0 & 0 & 0 \\
\hline Battery Size (kW) & 0 & 0 & 0 \\
\hline Diesel Generator Size (kW) & 0 & 0 & 0 \\
\hline PV Cost (\$) & 0 & 0 & 0 \\
\hline PV Cost Less NY Sun incentive (\$) & 0 & 0 & 0 \\
\hline Battery Cost (\$) & 0 & 0 & 0 \\
\hline Generator Cost (\$) & 0 & 0 & 0 \\
\hline Total Capital Cost (\$) & 0 & 0 & 0 \\
\hline Year 1 Electric Cost (\$) & 69,920 & 69,920 & 69,920 \\
\hline Year 1 Demand Cost (\$) & 191,751 & 191,751 & 191,751 \\
\hline Year 1 Electric Savings (\$) & 0 & 0 & 0 \\
\hline Year 1 Demand Savings (\$) & 0 & 0 & 0 \\
\hline Annual Resiliency Savings (\$) & 0 & 0 & 0 \\
\hline LCC (\$) & $5,385,190$ & $5,393,890$ & $5,446,340$ \\
\hline NPV (\$) & 0 & 0 & 0 \\
\hline SPP (years) & 0 & 0 & 0 \\
\hline Diesel Fuel Used (gallons) & 0 & 0 & 0 \\
\hline Incentive Required to get to NPV=0 (\%) & 0 & 0 & 0 \\
\hline
\end{tabular}


Table D-2. School Shelter Scenario 1: Resilient PV Sized for Economic Savings

\begin{tabular}{|c|c|c|c|}
\hline Scenario Number & 1.1 & 1.2 & 1.3 \\
\hline Description & No resiliency value & $\begin{array}{l}2 \text { hour resiliency } \\
\text { value }\end{array}$ & $\begin{array}{l}22 \text { hour resiliency } \\
\text { value }\end{array}$ \\
\hline Outage START (hour of year) & - & - & - \\
\hline Outage STOP (hour of year) & - & - & - \\
\hline Resiliency Value (\$/hour) & 0 & $68.97,7.25$ hours & $68.97,7.25$ hours \\
\hline Outage Duration (hours) & 0 & 0 & 0 \\
\hline PV Size (kW-DC) & 50 & 50 & 50 \\
\hline Battery Size (kWh) & 73.76 & 73.76 & 73.76 \\
\hline Battery Size (kW) & 34.86 & 34.86 & 34.86 \\
\hline Diesel Generator Size (kW) & 0 & 0 & 0 \\
\hline PV Cost (\$) & 172,500 & 172,500 & 172,500 \\
\hline PV Cost Less NY Sun incentive (\$) & 132,500 & 132,500 & 132,500 \\
\hline Battery Cost (\$) & 73,216 & 73,216 & 73,216 \\
\hline Generator Cost (\$) & 0 & 0 & 0 \\
\hline Total Capital Cost (\$) & 205,716 & 205,716 & 205,716 \\
\hline Year 1 Electric Cost (\$) & 69,652 & 69,652 & 69,652 \\
\hline Year 1 Demand Cost (\$) & 177,620 & 177,620 & 177,620 \\
\hline Year 1 Electric Savings (\$) & 268 & 268 & 268 \\
\hline Year 1 Demand Savings (\$) & 14,131 & 14,131 & 14,131 \\
\hline Annual Resiliency Savings (\$) & - & 413 & 413 \\
\hline $\operatorname{LCC}(\$)$ & $5,333,630$ & $5,335,240$ & $5,335,240$ \\
\hline NPV (\$) & 51,560 & 58,650 & 58,650 \\
\hline SPP (years) & 14.29 & 13.89 & 13.89 \\
\hline Diesel Fuel Used (gallons) & 0 & 0 & 0 \\
\hline Incentive Required to get to NPV=0 (\%) & 0 & 0 & 0 \\
\hline \multicolumn{4}{|c|}{ Size of Critical Load that Can Be Supported for Full Length of Outage (\%) } \\
\hline 7 Hour Outage- Worst & $46 \%$ & $46 \%$ & $46 \%$ \\
\hline 7 Hour Outage- Best & $285 \%$ & $285 \%$ & $285 \%$ \\
\hline 51 Hour Outage- Worst & $12 \%$ & $12 \%$ & $12 \%$ \\
\hline 51 Hour Outage- Best & $50 \%$ & $50 \%$ & $50 \%$ \\
\hline
\end{tabular}


Table D-3. School Shelter Scenario 2: Resilient PV Sized to Meet Resiliency Needs

\begin{tabular}{|c|c|c|c|c|}
\hline Scenario Number & 2.1.a & 2.1.b & 2.2.a & $2.2 . b$ \\
\hline Description & $\begin{array}{r}2 \text { hour } \\
\text { outage, no } \\
\text { resiliency } \\
\text { value }\end{array}$ & $\begin{array}{r}2 \text { hour } \\
\text { outage, with } \\
\text { resiliency } \\
\text { value }\end{array}$ & $\begin{array}{r}22 \text { hour } \\
\text { outage, no } \\
\text { resiliency } \\
\text { value }\end{array}$ & $\begin{array}{r}22 \text { hour } \\
\text { outage, with } \\
\text { resiliency } \\
\text { value }\end{array}$ \\
\hline Outage START (hour of year) & 8584 & 8584 & 8394 & 8394 \\
\hline Outage STOP (hour of year) & 8590 & 8590 & 8444 & 8444 \\
\hline Resiliency Value (\$/hour) & 0 & 68.97 & 0 & 68.97 \\
\hline Outage Duration (hours) & 7.25 & 7.25 & 50.96 & 50.96 \\
\hline PV Size (kW-DC) & 50 & 50 & 200 & 200 \\
\hline Battery Size (kWh) & 202.71 & 202.71 & 984.93 & 984.93 \\
\hline Battery Size (kW) & 68.38 & 68.38 & 157.60 & 157.60 \\
\hline Diesel Generator Size (kW) & 0 & 0 & 0 & 0 \\
\hline PV Cost (\$) & 172,500 & 172,500 & 690,000 & 690,000 \\
\hline PV Cost Less NY Sun incentive (\$) & 132,500 & 132,500 & 575,000 & 575,000 \\
\hline Battery Cost (\$) & 173,782 & 173,782 & 669,758 & 669,758 \\
\hline Generator Cost (\$) & - & - & - & - \\
\hline Total Capital Cost (\$) & 306,282 & 306,282 & $1,244,758$ & $1,244,758$ \\
\hline Year 1 Electric Cost (\$) & 67,235 & 67,235 & 64,644 & 64,644 \\
\hline Year 1 Demand Cost (\$) & 168,837 & 168,837 & 129,225 & 129,225 \\
\hline Year 1 Electric Savings (\$) & 2,685 & 2,685 & 5,276 & 5,276 \\
\hline Year 1 Demand Savings (\$) & 22,914 & 22,914 & 62,526 & 62,526 \\
\hline Annual Resiliency Savings (\$) & 0 & 500 & 0 & 3,515 \\
\hline LCC (\$) & $5,363,320$ & $5,363,320$ & $5,908,670$ & $5,908,670$ \\
\hline NPV (\$) & 21,870 & 30,570 & $(523,480)$ & $(462,330)$ \\
\hline SPP (years) & 11.96 & 11.74 & 18.36 & 17.45 \\
\hline Diesel Fuel Used (gallons) & 0 & 0 & 0 & 0 \\
\hline Incentive Required to get to NPV=0 (\%) & 0 & 0 & $42 \%$ & $37 \%$ \\
\hline
\end{tabular}


Table D-4. School Shelter Scenario 3: Resilient PV and Generator (Hybrid System) Sized to Meet Resiliency Needs

\begin{tabular}{|c|c|c|c|c|}
\hline Scenario Number & 3.1.a & 3.1.b & 3.2.a & 3.2.b \\
\hline Description & $\begin{array}{r}2 \text { hour outage, } \\
\text { no resiliency } \\
\text { value }\end{array}$ & $\begin{array}{r}2 \text { hour outage, } \\
\text { with resiliency } \\
\text { value }\end{array}$ & $\begin{array}{r}22 \text { hour } \\
\text { outage, no } \\
\text { resiliency value }\end{array}$ & $\begin{array}{r}22 \text { hour } \\
\text { outage, with } \\
\text { resiliency value }\end{array}$ \\
\hline Outage START (hour of year) & 8584 & 8584 & 8394 & 8394 \\
\hline Outage STOP (hour of year) & 8590 & 8590 & 8444 & 8444 \\
\hline Resiliency Value (\$/hour) & 0 & 68.97 & 0 & 68.97 \\
\hline Outage Duration (hours) & 7.25 & 7.25 & 50.96 & 50.96 \\
\hline PV Size (kW-DC) & 50 & 50 & 50 & 50 \\
\hline Battery Size (kWh) & 117.93 & 117.93 & 87.03 & 87.03 \\
\hline Battery Size (kW) & 47.62 & 47.62 & 39.38 & 39.38 \\
\hline Diesel Generator Size (kW) & 9.69 & 9.69 & 18.13 & 18.13 \\
\hline PV Cost (\$) & 172,500 & 172,500 & 172,500 & 172,500 \\
\hline PV Cost Less NY Sun incentive (\$) & 132,500 & 132,500 & 132,500 & 132,500 \\
\hline Battery Cost (\$) & 108,939 & 108,939 & 84,636 & 84,636 \\
\hline Generator Cost (\$) & 14,535 & 14,535 & 27,195 & 27,195 \\
\hline Total Capital Cost (\$) & 255,974 & 255,974 & 244,331 & 244,331 \\
\hline Year 1 Electric Cost (\$) & 69,635 & 69,635 & 69,447 & 69,447 \\
\hline Year 1 Demand Cost (\$) & 174,330 & 174,330 & 176,492 & 176,492 \\
\hline Year 1 Electric Savings (\$) & 285 & 285 & 473 & 473 \\
\hline Year 1 Demand Savings (\$) & 17,421 & 17,421 & 15,259 & 15,259 \\
\hline Annual Resiliency Savings (\$) & - & 500 & - & 3,515 \\
\hline LCC (\$) & $5,361,540$ & $5,361,540$ & $5,367,810$ & $5,367,810$ \\
\hline NPV (\$) & 23,650 & 32,350 & 17,380 & 78,530 \\
\hline SPP (years) & 14.46 & 14.06 & 15.53 & 12.69 \\
\hline Diesel Fuel Used (gallons) & 7.94 & 7.94 & 88.42 & 88.42 \\
\hline $\begin{array}{l}\text { Incentive Required to get to } \\
\mathrm{NPV}=0 \text { (\%) }\end{array}$ & 0 & 0 & 0 & 0 \\
\hline
\end{tabular}


Table D-5. School Shelter Scenario 4: Generator Sized to Meet Resiliency Needs

\begin{tabular}{|c|c|c|c|c|}
\hline Scenario Number & 4.1.a & 4.1.b & 4.2.a & 4.2.b \\
\hline Description & $\begin{array}{r}2 \text { hour outage, } \\
\text { no resiliency } \\
\text { value }\end{array}$ & $\begin{array}{r}2 \text { hour outage, } \\
\text { with resiliency } \\
\text { value }\end{array}$ & $\begin{array}{r}22 \text { hour } \\
\text { outage, no } \\
\text { resiliency value }\end{array}$ & $\begin{array}{r}22 \text { hour outage, } \\
\text { with resiliency } \\
\text { value }\end{array}$ \\
\hline Outage START (hour of year) & 8584 & 8584 & 8394 & 8394 \\
\hline Outage STOP (hour of year) & 8590 & 8590 & 8444 & 8444 \\
\hline Resiliency Value (\$/hour) & 0 & 68.97 & 0 & 68.97 \\
\hline Outage Duration (hours) & 7.25 & 7.25 & 50.96 & 50.96 \\
\hline PV Size (kW-DC) & 0 & 0 & 0 & 0 \\
\hline Battery Size (kWh) & 0 & 0 & 0 & 0 \\
\hline Battery Size (kW) & 0 & 0 & 0 & 0 \\
\hline Diesel Generator Size (kW) & 29.9 & 29.9 & 32.6 & 32.6 \\
\hline PV Cost (\$) & 0 & 0 & 0 & 0 \\
\hline PV Cost Less NY Sun incentive (\$) & 0 & 0 & 0 & 0 \\
\hline Battery Cost (\$) & 0 & 0 & 0 & 0 \\
\hline Generator Cost (\$) & 44,850 & 44,850 & 48,900 & 48,900 \\
\hline Total Capital Cost (\$) & 44,850 & 44,850 & 48,900 & 48,900 \\
\hline Year 1 Electric Cost (\$) & 69,920 & 69,920 & 70,158 & 70,158 \\
\hline Year 1 Demand Cost (\$) & 191,751 & 191,751 & 191,751 & 191,751 \\
\hline Year 1 Electric Savings (\$) & (1) & (1) & (239) & (239) \\
\hline Year 1 Demand Savings (\$) & 0 & 0 & 0 & 0 \\
\hline Annual Resiliency Savings (\$) & 0 & 500 & 0 & 3,515 \\
\hline LCC (\$) & $5,446,660$ & $5,446,660$ & $5,448,740$ & $5,448,740$ \\
\hline NPV (\$) & $(61,470)$ & $(52,770)$ & $(63,550)$ & $(2,400)$ \\
\hline SPP (years) & N/A & $\mathrm{N} / \mathrm{A}$ & N/A & 14.93 \\
\hline Diesel Fuel Used (gallons) & 14.78 & 14.78 & 97.67 & 97.67 \\
\hline $\begin{array}{l}\text { Incentive Required to get to NPV=0 } \\
\text { (\%) }\end{array}$ & $\mathrm{N} / \mathrm{A}$ & $\mathrm{N} / \mathrm{A}$ & N/A & N/A \\
\hline
\end{tabular}




\section{FDNY}

Table D-6. Fire Station Baseline: No Resilient PV

\begin{tabular}{|c|c|c|c|}
\hline Scenario Number & 0.1 & 0.2 & 0.3 \\
\hline Description & $\begin{array}{l}\text { Without cost of grid } \\
\text { interruptions }\end{array}$ & $\begin{array}{c}\text { With cost of } 2 \\
\text { hours/year grid } \\
\text { interruptions }\end{array}$ & $\begin{array}{c}\text { With cost of } 22 \\
\text { hours/year grid } \\
\text { interruptions }\end{array}$ \\
\hline Outage START (hour of year) & - & - & - \\
\hline \multicolumn{4}{|l|}{ Outage STOP (hour of year) } \\
\hline Resiliency Value (\$/hour) & 0 & $\begin{array}{l}\$ 917.43 / \mathrm{hr} \\
2 \text { hours }\end{array}$ & $\begin{array}{r}917.43 / \mathrm{hr} \\
22 \text { hours }\end{array}$ \\
\hline Outage Duration (hours) & 0 & 0 & 0 \\
\hline PV Size (kW-DC) & 0 & 0 & 0 \\
\hline Battery Size (kWh) & 0 & 0 & 0 \\
\hline Battery Size (kW) & 0 & 0 & 0 \\
\hline Diesel Generator Size (kW) & 0 & 0 & 0 \\
\hline PV Cost (\$) & 0 & 0 & 0 \\
\hline PV Cost Less NY Sun incentive (\$) & 0 & 0 & 0 \\
\hline Battery Cost (\$) & 0 & 0 & 0 \\
\hline Generator Cost (\$) & 0 & 0 & 0 \\
\hline Total Capital Cost (\$) & 0 & 0 & 0 \\
\hline Year 1 Electric Cost (\$) & 6,092 & 6,092 & 6,092 \\
\hline Year 1 Demand Cost (\$) & 15,214 & 15,214 & 15,214 \\
\hline Year 1 Electric Savings (\$) & 0 & 0 & 0 \\
\hline Year 1 Demand Savings (\$) & 0 & 0 & 0 \\
\hline Annual Resiliency Savings (\$) & 0 & 0 & 0 \\
\hline LCC (\$) & 438,478 & 470,245 & 787,754 \\
\hline NPV (\$) & 0 & 0 & 0 \\
\hline SPP (years) & 0 & 0 & 0 \\
\hline Diesel Fuel Used (gallons) & 0 & 0 & 0 \\
\hline Incentive Required to get to NPV=0 (\%) & 0 & 0 & 0 \\
\hline
\end{tabular}


Table D-7. Fire Station Scenario 1: Resilient PV Sized for Economic Savings

\begin{tabular}{|c|c|c|c|c|c|c|}
\hline Scenario Number & 1.1 & 1.1 Solar & 1.2 & 1.2 Solar & 1.3 & 1.3 Solar \\
\hline Description & $\begin{array}{l}\text { No } \\
\text { resiliency } \\
\text { value }\end{array}$ & $\begin{array}{l}\text { No } \\
\text { resiliency } \\
\text { value, } \\
\text { require PV }\end{array}$ & $\begin{array}{l}2 \text { hour } \\
\text { resiliency } \\
\text { value }\end{array}$ & $\begin{array}{l}2 \text { hour } \\
\text { resiliency } \\
\text { value, } \\
\text { require PV }\end{array}$ & $\begin{array}{l}22 \text { hour } \\
\text { resiliency } \\
\text { value }\end{array}$ & $\begin{array}{l}\mathbf{2 2} \text { hour } \\
\text { resiliency } \\
\text { value, } \\
\text { require PV }\end{array}$ \\
\hline Outage START (hour of year) & - & - & - & - & - & - \\
\hline Outage STOP (hour of year) & - & - & - & - & - & - \\
\hline Resiliency Value (\$/hour) & 0 & 0 & $\$ 917.43 / \mathrm{hr}$ & $\$ 917.43 / \mathrm{hr}$ & $\$ 917.43 / \mathrm{hr}$ & $\$ 917.43 / \mathrm{hr}$ \\
\hline & & & $2 \mathrm{hrs}$ & $2 \mathrm{hrs}$ & $22 \mathrm{hrs}$ & $22 \mathrm{hrs}$ \\
\hline Outage Duration (hours) & 0 & 0 & 0 & 0 & 0 & 0 \\
\hline PV Size (kW-DC) & 0 & 10.0 & 0 & 10.0 & 0 & 10.0 \\
\hline Battery Size (kWh) & 60.1 & 42.5 & 60.1 & 42.5 & 214.3 & 213.0 \\
\hline Battery Size (kW) & 18.7 & 16.5 & 18.7 & 16.5 & 29.8 & 31.2 \\
\hline Diesel Generator Size (kW) & 0 & 0 & 0 & 0 & 0 & 0 \\
\hline PV Cost (\$) & 0 & 38,800 & 0 & 38,800 & 0 & 38,800 \\
\hline PV Cost Less NY Sun incentive (\$) & 0 & 30,800 & 0 & 30,800 & 0 & 30,800 \\
\hline Battery Cost (\$) & 49,945 & 38,613 & 49,945 & 38,613 & 141,226 & 141,941 \\
\hline Generator Cost (\$) & 0 & 0 & 0 & 0 & 0 & 0 \\
\hline Total Capital Cost (\$) & 49,945 & 69,413 & 49,945 & 69,413 & 141,226 & 172,741 \\
\hline Year 1 Electric Cost (\$) & 6,095 & 5,987 & 6,095 & 5,576 & 6,122 & 5,590 \\
\hline Year 1 Demand Cost (\$) & 10,888 & 10,943 & 10,888 & 10,943 & 8,240 & 7,263 \\
\hline Year 1 Electric Savings (\$) & (3) & 105 & (3) & 516 & (30) & 502 \\
\hline Year 1 Demand Savings (\$) & 4,327 & 4,271 & 4,327 & 4,271 & 6,974 & 7,951 \\
\hline Annual Resiliency Savings (\$) & 0 & 0 & 1,826 & 1,826 & 20,073 & 20,073 \\
\hline $\operatorname{LCC}(\$)$ & 404,498 & 416,113 & 404,498 & 416,113 & 452,415 & 463,504 \\
\hline NPV (\$) & 33,980 & 22,365 & 65,747 & 54,132 & 335,339 & 324,250 \\
\hline SPP (years) & 11.55 & 15.86 & 8.12 & 10.50 & 5.23 & 6.06 \\
\hline Diesel Fuel Used (gallons) & 0 & 0 & 0 & 0 & 0 & 0 \\
\hline Incentive Required to get to NPV=0 (\%) & 0 & 0 & 0 & 0 & 0 & 0 \\
\hline \multicolumn{7}{|c|}{ Size of Critical Load that Can Be Supported for Full Length of Outage (\%) } \\
\hline 2 Hour Outage- Worst & & $41 \%$ & & $41 \%$ & & $77 \%$ \\
\hline 2 Hour Outage- Best & & $732 \%$ & & $732 \%$ & & $1181 \%$ \\
\hline 22 Hour Outage- Worst & & $2.4 \%$ & & $2.4 \%$ & & $47 \%$ \\
\hline 22 Hour Outage- Best & & $73 \%$ & & $73 \%$ & & $264 \%$ \\
\hline
\end{tabular}


Table D-8. Fire Station Scenario 2: Resilient PV Sized to Meet Resiliency Needs

\begin{tabular}{|c|c|c|c|c|c|}
\hline Scenario Number & 2.1.a & 2.1.b & 2.1.b Solar & 2.2.a & $2.2 . b$ \\
\hline Description & $\begin{array}{r}2 \text { hour } \\
\text { outage, no } \\
\text { resiliency } \\
\text { value }\end{array}$ & $\begin{array}{r}2 \text { hour } \\
\text { outage, with } \\
\text { resiliency } \\
\text { value }\end{array}$ & $\begin{array}{r}2 \text { hour outage, } \\
\text { with resiliency } \\
\text { value, require } \\
\text { PV }\end{array}$ & $\begin{array}{r}22 \text { hour } \\
\text { outage, no } \\
\text { resiliency } \\
\text { value }\end{array}$ & $\begin{array}{r}22 \text { hour } \\
\text { outage, with } \\
\text { resiliency } \\
\text { value }\end{array}$ \\
\hline Outage START (hour of year) & 6015 & 6015 & 6015 & 6004 & 6004 \\
\hline Outage STOP (hour of year) & 6016 & 6016 & 6016 & 6025 & 6025 \\
\hline Resiliency Value (\$/hour) & 0 & 917.43 & 917.43 & 0 & 917.43 \\
\hline Outage Duration (hours) & 1.99 & 1.99 & 1.99 & 21.88 & 21.88 \\
\hline PV Size (kW-DC) & 0.0 & 0.0 & 10.0 & 10.0 & 10.0 \\
\hline Battery Size (kWh) & 136.3 & 136.3 & 130.5 & 613.0 & 613.0 \\
\hline Battery Size (kW) & 41.1 & 41.1 & 40.2 & 40.2 & 40.2 \\
\hline Diesel Generator Size (kW) & 0 & 0 & 0 & 0 & 0 \\
\hline PV Cost (\$) & 0 & 0 & 38,800 & 38,800 & 38,800 \\
\hline $\begin{array}{l}\text { PV Cost Less NY Sun incentive } \\
\text { (\$) }\end{array}$ & 0 & 0 & 30,800 & 30,800 & 30,800 \\
\hline Battery Cost (\$) & 111,930 & 111,930 & 108,028 & 358,906 & 358,906 \\
\hline Generator Cost (\$) & 0 & 0 & 0 & 0 & 0 \\
\hline Total Capital Cost (\$) & 111,930 & 111,930 & 138,828 & 389,706 & 389,706 \\
\hline Year 1 Electric Cost (\$) & 6,099 & 6,099 & 5,575 & 5,584 & 5,584 \\
\hline Year 1 Demand Cost (\$) & 9,802 & 9,802 & 9,356 & 7,038 & 7,038 \\
\hline Year 1 Electric Savings (\$) & (7) & (7) & 517 & 508 & 508 \\
\hline Year 1 Demand Savings (\$) & 5,412 & 5,412 & 5,858 & 8,176 & 8,176 \\
\hline Annual Resiliency Savings (\$) & 0 & 1,826 & 1,826 & 0 & 20,073 \\
\hline LCC (\$) & 450,548 & 450,548 & 460,096 & 694,636 & 694,636 \\
\hline NPV (\$) & $(12,070)$ & 19,697 & 10,149 & $(256,158)$ & 93,118 \\
\hline SPP (years) & 20.71 & 15.48 & 16.93 & 44.88 & 13.55 \\
\hline Diesel Fuel Used (gallons) & 0.00 & 0.00 & 1.00 & 0.00 & 0.00 \\
\hline $\begin{array}{l}\text { Incentive Required to get to } \\
\mathrm{NPV}=0 \text { (\%) }\end{array}$ & $11 \%$ & 0 & 0 & $66 \%$ & 0 \\
\hline
\end{tabular}

Note: We did not run a separate "Solar" case requiring PV for Scenario 2.1.a because there are not positive NPV savings to subsidize the cost of PV. Solar is already part of the cost-optimal solution in Scenario 2.2.a and 2.2.b, so we did not run a separate "Solar" case requiring PV for these two scenarios. 
Table D-9. Fire Station Scenario 3: Resilient PV and Generator (Hybrid System) Sized to Meet Resiliency Needs

\begin{tabular}{|c|c|c|c|c|c|c|}
\hline Scenario Number & 3.1.a & 3.1.a SOLAR & 3.1.b & 3.1.b Solar & 3.2.a & 3.2.b \\
\hline Description & $\begin{array}{r}2 \text { hour } \\
\text { outage, no } \\
\text { resiliency } \\
\text { value }\end{array}$ & $\begin{array}{r}2 \text { hour } \\
\text { outage, no } \\
\text { resiliency } \\
\text { value, require } \\
\text { PV }\end{array}$ & $\begin{array}{r}2 \text { hour } \\
\text { outage, } \\
\text { with } \\
\text { resiliency } \\
\text { value }\end{array}$ & $\begin{array}{r}2 \text { hour } \\
\text { outage, with } \\
\text { resiliency } \\
\text { value, require } \\
\text { PV }\end{array}$ & $\begin{array}{r}22 \text { hour } \\
\text { outage, no } \\
\text { resiliency } \\
\text { value }\end{array}$ & $\begin{array}{r}22 \text { hour } \\
\text { outage, with } \\
\text { resiliency } \\
\text { value }\end{array}$ \\
\hline Outage START (hour of year) & 6015 & 6015 & 6015 & 6015 & 6004 & 6004 \\
\hline Outage STOP (hour of year) & 6016 & 6016 & 6016 & 6016 & 6025 & 6025 \\
\hline Resiliency Value (\$/hour) & 0 & 0 & 917.43 & 917.43 & 0 & 917.43 \\
\hline Outage Duration (hours) & 1.99 & 1.99 & 1.99 & 1.99 & 21.88 & 21.88 \\
\hline PV Size (kW-DC) & 0.0 & 4.0 & 0.0 & 10.0 & 0.6 & 0.6 \\
\hline Battery Size (kWh) & 74.1 & 73.2 & 74.1 & 74.3 & 60.5 & 60.5 \\
\hline Battery Size (kW) & 19.0 & 18.2 & 19.0 & 18.3 & 16.5 & 16.5 \\
\hline Diesel Generator Size (kW) & 22.11 & 22.51 & 22.11 & 21.86 & 26.30 & 26.30 \\
\hline PV Cost (\$) & 0 & 15,520 & 0 & 38,800 & 2,483 & 2,483 \\
\hline PV Cost Less NY Sun incentive (\$) & 0 & 12,320 & 0 & 30,800 & 1,971 & 1,971 \\
\hline Battery Cost (\$) & 57,466 & 56,243 & 57,466 & 56,915 & 47,960 & 47,960 \\
\hline Generator Cost (\$) & 33,165 & 33,765 & 33,165 & 32,790 & 39,450 & 39,450 \\
\hline Total Capital Cost (\$) & 90,631 & 102,328 & 90,631 & 120,505 & 89,381 & 89,381 \\
\hline Year 1 Electric Cost (\$) & 6,118 & 5,908 & 6,118 & 5,594 & 6,122 & 6,122 \\
\hline Year 1 Demand Cost (\$) & 10,392 & 10,085 & 10,392 & 9,729 & 10,673 & 10,673 \\
\hline Year 1 Electric Savings (\$) & (26) & 184 & (26) & 498 & (30) & (30) \\
\hline Year 1 Demand Savings (\$) & 4,822 & 5,129 & 4,822 & 5,485 & 4,541 & 4,541 \\
\hline Annual Resiliency Savings (\$) & 0 & 0 & 1,826 & 1,826 & 0 & 20,073 \\
\hline LCC (\$) & 436,052 & 438,478 & 436,052 & 444,861 & 440,157 & 440,157 \\
\hline NPV (\$) & 2,426 & 0 & 34,193 & 25,384 & $(1,679)$ & 347,597 \\
\hline SPP (years) & 18.90 & 19.26 & 13.69 & 15.43 & 19.81 & 3.64 \\
\hline Diesel Fuel Used (gallons) & 4.06 & 4.12 & 4.06 & 4.03 & 43.30 & 43.30 \\
\hline $\begin{array}{l}\text { Incentive Required to get to } \\
\mathrm{NPV}=0 \text { (\%) }\end{array}$ & 0 & 0 & 0 & 0 & 0 & 0 \\
\hline
\end{tabular}

Note: Solar is already part of the cost-optimal solution in Scenario 3.2.a and 3.2.b, so we did not run a separate

"Solar" case requiring PV for these two scenarios. 
Table D-10. Fire Station Scenario 4: Generator Sized to Meet Resiliency Needs

\begin{tabular}{|c|c|c|c|c|}
\hline Scenario Number & 4.1.a & 4.1.b & 4.2.a & 4.2.b \\
\hline Description & $\begin{array}{r}2 \text { hour outage, } \\
\text { no resiliency } \\
\text { value }\end{array}$ & $\begin{array}{r}2 \text { hour outage, } \\
\text { with resiliency } \\
\text { value }\end{array}$ & $\begin{array}{r}22 \text { hour } \\
\text { outage, no } \\
\text { resiliency value }\end{array}$ & $\begin{array}{r}22 \text { hour outage, } \\
\text { with resiliency } \\
\text { value }\end{array}$ \\
\hline Outage START (hour of year) & 6015 & 6015 & 6004 & 6004 \\
\hline Outage STOP (hour of year) & 6016 & 6016 & 6025 & 6025 \\
\hline Resiliency Value (\$/hour) & - & 917.43 & - & 917.43 \\
\hline Outage Duration (hours) & 1.99 & 1.99 & 21.88 & 21.88 \\
\hline PV Size (kW-DC) & 0.0 & 0.0 & 0.0 & 0.0 \\
\hline Battery Size (kWh) & 0.0 & 0.0 & 0.0 & 0.0 \\
\hline Battery Size (kW) & 0.0 & 0.0 & 0.0 & 0.0 \\
\hline Diesel Generator Size (kW) & 41.08 & 41.08 & 41.08 & 41.08 \\
\hline PV Cost (\$) & 0 & 0 & 0 & 0 \\
\hline PV Cost Less NY Sun incentive (\$) & 0 & 0 & 0 & 0 \\
\hline Battery Cost (\$) & 0 & 0 & 0 & 0 \\
\hline Generator Cost (\$) & 61,620 & 61,620 & 61,620 & 61,620 \\
\hline Total Capital Cost (\$) & 61,620 & 61,620 & 61,620 & 61,620 \\
\hline Year 1 Electric Cost (\$) & 6,100 & 6,100 & 6,157 & 6,157 \\
\hline Year 1 Demand Cost (\$) & 14,725 & 14,725 & 14,725 & 14,725 \\
\hline Year 1 Electric Savings (\$) & (8) & (8) & (65) & (65) \\
\hline Year 1 Demand Savings (\$) & 489 & 489 & 489 & 489 \\
\hline Annual Resiliency Savings (\$) & - & 1,826 & - & 20,073 \\
\hline LCC (\$) & 490,209 & 490,209 & 491,374 & 491,374 \\
\hline NPV (\$) & $(51,731)$ & $(19,964)$ & $(52,896)$ & 296,380 \\
\hline SPP (years) & 128.15 & 26.72 & 145.38 & 3.01 \\
\hline Diesel Fuel Used (gallons) & 6.50 & 6.50 & 47.20 & 47.20 \\
\hline $\begin{array}{l}\text { Incentive Required to get to NPV=0 } \\
\text { (\%) }\end{array}$ & N/A & $\mathrm{N} / \mathrm{A}$ & $\mathrm{N} / \mathrm{A}$ & $\mathrm{N} / \mathrm{A}$ \\
\hline
\end{tabular}




\section{NYCHA}

Table D-11. Cooling Center Baseline: No Resilient PV

\begin{tabular}{|c|c|c|c|}
\hline Scenario Number & 0.1 & 0.2 & 0.3 \\
\hline Description & $\begin{array}{l}\text { Without cost of grid } \\
\text { interruptions }\end{array}$ & $\begin{array}{l}\text { With cost of } 7 \\
\text { hours/year grid } \\
\text { interruptions }\end{array}$ & $\begin{array}{c}\text { With cost of } 51 \\
\text { hours/year grid } \\
\text { interruptions }\end{array}$ \\
\hline Outage START (hour of year) & - & - & - \\
\hline Outage STOP (hour of year) & - & - & - \\
\hline Resiliency Value (\$/hour) & 0 & $32.02,7.25$ hours & $32.02,50.96$ hours \\
\hline Outage Duration (hours) & 0 & 0 & 0 \\
\hline PV Size (kW-DC) & 0 & 0 & 0 \\
\hline Battery Size (kWh) & 0 & 0 & 0 \\
\hline Battery Size (kW) & 0 & 0 & 0 \\
\hline Diesel Generator Size (kW) & 0 & 0 & 0 \\
\hline PV Cost (\$) & 0 & 0 & 0 \\
\hline PV Cost Less NY Sun incentive (\$) & 0 & 0 & 0 \\
\hline Battery Cost (\$) & 0 & 0 & 0 \\
\hline Generator Cost (\$) & 0 & 0 & 0 \\
\hline Total Capital Cost (\$) & 0 & 0 & 0 \\
\hline Year 1 Electric Cost (\$) & 14,047 & 14,047 & 14,047 \\
\hline Year 1 Demand Cost (\$) & 31,736 & 31,736 & 31,736 \\
\hline Year 1 Electric Savings (\$) & 0 & 0 & 0 \\
\hline Year 1 Demand Savings (\$) & 0 & 0 & 0 \\
\hline Annual Resiliency Savings (\$) & 0 & 0 & 0 \\
\hline LCC (\$) & 942,194 & 946,233 & 970,586 \\
\hline NPV (\$) & 0 & 0 & 0 \\
\hline SPP (years) & 0 & 0 & 0 \\
\hline Diesel Fuel Used (gallons) & 0 & 0 & 0 \\
\hline Incentive Required to get to NPV=0 (\%) & 0 & 0 & 0 \\
\hline
\end{tabular}


Table D-12. Cooling Center Scenario 1: Resilient PV Sized for Economic Savings

\begin{tabular}{|c|c|c|c|c|c|c|}
\hline Scenario Number & 1.1 & 1.1 Solar & 1.2 & 1.2 Solar & 1.3 & 1.3 Solar \\
\hline Description & $\begin{array}{l}\text { No } \\
\text { resiliency } \\
\text { value }\end{array}$ & $\begin{array}{l}\text { No } \\
\text { resiliency } \\
\text { value, } \\
\text { require } \\
\text { PV }\end{array}$ & $\begin{array}{l}7 \text { hour } \\
\text { resiliency } \\
\text { value }\end{array}$ & $\begin{array}{l}7 \text { hour } \\
\text { resiliency } \\
\text { value, } \\
\text { require } \\
\text { PV }\end{array}$ & $\begin{array}{l}51 \text { hour } \\
\text { resiliency } \\
\text { value }\end{array}$ & $\begin{array}{l}51 \text { hour } \\
\text { resiliency } \\
\text { value, } \\
\text { require } \\
\text { PV }\end{array}$ \\
\hline Outage START (hour of year) & - & - & - & - & - & \\
\hline Outage STOP (hour of year) & - & - & - & - & - & - \\
\hline Resiliency Value (\$/hour) & 0 & 0 & $\begin{array}{r}32.02 \\
7.25 \text { hours }\end{array}$ & $\begin{array}{r}32.02 \\
7.25 \text { hours }\end{array}$ & $\begin{array}{r}32.02 \\
50.96 \\
\text { hours }\end{array}$ & $\begin{array}{r}32.02, \\
50.96 \\
\text { hours }\end{array}$ \\
\hline Outage Duration (hours) & 0 & 0 & 0 & 0 & 0 & 0 \\
\hline PV Size (kW-DC) & 0 & 7 & 0 & 9 & 0 & 9 \\
\hline Battery Size (kWh) & 23.88 & 24.75 & 24.75 & 24.75 & 24.75 & 25.38 \\
\hline Battery Size (kW) & 6.44 & 6.54 & 6.56 & 6.53 & 6.56 & 6.62 \\
\hline Diesel Generator Size (kW) & 0 & 0 & 0 & 0 & 0 & 0 \\
\hline PV Cost (\$) & 0 & 32,480 & 0 & 37,120 & 0 & 37,120 \\
\hline PV Cost Less NY Sun incentive (\$) & 0 & 26,880 & 0 & 30,720 & 0 & 30,720 \\
\hline Battery Cost (\$) & 18,857 & 19,406 & 19,430 & 19,400 & 19,430 & 19,818 \\
\hline Generator Cost (\$) & 0 & 0 & 0 & 0 & 0 & 0 \\
\hline Total Capital Cost (\$) & 18,857 & 46,286 & 19,430 & 50,120 & 19,430 & 50,538 \\
\hline Year 1 Electric Cost (\$) & 14,039 & 14,034 & 14,039 & 13,627 & 14,039 & 13,628 \\
\hline Year 1 Demand Cost (\$) & 28,877 & 28,771 & 28,818 & 28,767 & 28,818 & 28727 \\
\hline Year 1 Electric Savings (\$) & 8 & 13 & 8 & 420 & 8 & 419 \\
\hline Year 1 Demand Savings (\$) & 2,859 & 2,965 & 2,918 & 2,969 & 2,918 & 3,009 \\
\hline Annual Resiliency Savings (\$) & - & - & 187 & 174 & 187 & 1,142 \\
\hline LCC (\$) & 922,673 & 941,781 & 923,456 & 944,550 & 947,809 & 968,724 \\
\hline NPV (\$) & 19,521 & 413 & 22,777 & 1,683 & 22,777 & 1,862 \\
\hline SPP (years) & 6.58 & 15.55 & 6.24 & 14.07 & 6.24 & 11.06 \\
\hline Diesel Fuel Used (gallons) & - & - & 0 & 0 & 0 & 0 \\
\hline $\begin{array}{l}\text { Incentive Required to get to NPV=0 } \\
\text { (\%) }\end{array}$ & 0 & 0 & 0 & 0 & 0 & 0 \\
\hline \multicolumn{7}{|c|}{ Size of Critical Load that Can Be Supported for Full Length of Outage (\%) } \\
\hline 2 Hour Outage- Worst & & $31 \%$ & & $32 \%$ & & $32 \%$ \\
\hline 2 Hour Outage- Best & & $2996 \%$ & & $3138 \%$ & & $3138 \%$ \\
\hline 22 Hour Outage- Worst & & $13 \%$ & & $13 \%$ & & $13 \%$ \\
\hline 22 Hour Outage- Best & & $20 \%$ & & $22 \%$ & & $22 \%$ \\
\hline
\end{tabular}


Table D-13. Cooling Center Scenario 2: Resilient PV Sized to Meet Resiliency Needs

\begin{tabular}{|c|c|c|c|c|}
\hline Scenario Number & 2.1.a & 2.1.b & 2.2.a & 2.2.b \\
\hline Description & $\begin{array}{r}7 \text { hour outage, no } \\
\text { resiliency value }\end{array}$ & $\begin{array}{r}7 \text { hour outage, } \\
\text { with resiliency } \\
\text { value }\end{array}$ & $\begin{array}{r}51 \text { hour outage, } \\
\text { no resiliency } \\
\text { value }\end{array}$ & $\begin{array}{r}51 \text { hour outage, } \\
\text { with resiliency } \\
\text { value }\end{array}$ \\
\hline Outage START (hour of year) & 5220 & 5220 & 5172 & 5172 \\
\hline Outage STOP (hour of year) & 5226 & 5226 & 5222 & 5222 \\
\hline Resiliency Value (\$/hour) & 0 & 32.02 & 0 & 32.02 \\
\hline Outage Duration (hours) & 7.25 & 7.25 & 50.96 & 50.96 \\
\hline PV Size (kW-DC) & 2.27 & 2.27 & 9 & 9 \\
\hline Battery Size (kWh) & 104.00 & 104.00 & 230.30 & 230.30 \\
\hline Battery Size (kW) & 12.11 & 12.11 & 12.69 & 12.69 \\
\hline Diesel Generator Size (kW) & 0 & 0 & 0 & 0 \\
\hline PV Cost (\$) & 10,533 & 10,533 & 41,760 & 41,760 \\
\hline PV Cost Less NY Sun incentive (\$) & 8,717 & 8,717 & 34,560 & 34,560 \\
\hline Battery Cost (\$) & 66,190 & 66,190 & 132,446 & 132,446 \\
\hline Generator Cost (\$) & 0 & 0 & 0 & 0 \\
\hline Total Capital Cost (\$) & 74,907 & 74,907 & 167,006 & 167,006 \\
\hline Year 1 Electric Cost (\$) & 13,893 & 13,893 & 13,399 & 13,399 \\
\hline Year 1 Demand Cost (\$) & 26,874 & 26,874 & 25,834 & 25,834 \\
\hline Year 1 Electric Savings (\$) & 154 & 154 & 648 & 648 \\
\hline Year 1 Demand Savings (\$) & 4,862 & 4,862 & 5,902 & 5,902 \\
\hline Annual Resiliency Savings (\$) & 0 & 232 & 0 & 1,632 \\
\hline LCC (\$) & 987,749 & 987,749 & $1,123,830$ & $1,123,830$ \\
\hline NPV (\$) & $(45,555)$ & $(41,516)$ & $(181,636)$ & $(153,244)$ \\
\hline SPP (years) & 14.94 & 13.26 & 25.50 & 15.17 \\
\hline Diesel Fuel Used (gallons) & 0 & 0 & 0 & 0 \\
\hline $\begin{array}{l}\text { Incentive Required to get to NPV=0 } \\
\text { (\%) }\end{array}$ & $61 \%$ & $55 \%$ & $109 \%$ & $92 \%$ \\
\hline
\end{tabular}

Note: We did not run separate "Solar" cases because solar is already part of the cost-optimal solutions. 
Table D-14. Cooling Center Scenario 3: Resilient PV and Generator (Hybrid System) Sized to Meet Resiliency Needs

\begin{tabular}{|c|c|c|c|c|c|c|}
\hline \multirow[t]{2}{*}{ Scenario Number } & 3.1.a & 3.1.b & 3.1.b & 3.2.a & 3.2.b & \multirow{2}{*}{$\begin{array}{l}3.2 . b \\
\text { SOLAR }\end{array}$} \\
\hline & & & SOLAR & & & \\
\hline Description & $\begin{array}{r}7 \text { hour } \\
\text { outage, no } \\
\text { resiliency } \\
\text { value }\end{array}$ & $\begin{array}{r}7 \text { hour } \\
\text { outage, } \\
\text { with } \\
\text { resiliency } \\
\text { value }\end{array}$ & $\begin{array}{r}7 \text { hour } \\
\text { outage, with } \\
\text { resiliency } \\
\text { value, } \\
\text { require PV }\end{array}$ & $\begin{array}{r}51 \text { hour } \\
\text { outage, } \\
\text { no } \\
\text { resiliency } \\
\text { value }\end{array}$ & $\begin{array}{r}51 \text { hour } \\
\text { outage, } \\
\text { with } \\
\text { resiliency } \\
\text { value }\end{array}$ & $\begin{array}{r}51 \text { hour } \\
\text { outage, } \\
\text { with } \\
\text { resiliency } \\
\text { value }\end{array}$ \\
\hline Outage START (hour of year) & 5220 & 5220 & 5220 & 5172 & 5172 & 5172 \\
\hline Outage STOP (hour of year) & 5226 & 5226 & 5226 & 5222 & 5222 & 5222 \\
\hline Resiliency Value (\$/hour) & 0 & 32.02 & 32.02 & 0 & 32.02 & 32.02 \\
\hline Outage Duration (hours) & 7.25 & 7.25 & 7.25 & 50.96 & 50.96 & 50.96 \\
\hline PV Size (kW-DC) & 0 & 0 & 2 & 0 & 0 & 9 \\
\hline Battery Size (kWh) & 25.38 & 25.38 & 27.80 & 25.38 & 25.38 & 35.13 \\
\hline Battery Size (kW) & 6.65 & 6.65 & 7.00 & 6.65 & 6.65 & 7.85 \\
\hline Diesel Generator Size (kW) & 9.30 & 9.30 & 8.75 & 9.69 & 9.69 & 6.81 \\
\hline PV Cost (\$) & 0 & 0 & 9,280 & 0 & 0 & 41,760 \\
\hline PV Cost Less NY Sun incentive (\$) & 0 & 0 & 7,680 & 0 & 0 & 34,560 \\
\hline Battery Cost (\$) & 19,848 & 19,848 & 21,456 & 19,845 & 19,845 & 26,118 \\
\hline Generator Cost (\$) & 13,950 & 13,950 & 13,125 & 14,531 & 14,531 & 10,215 \\
\hline Total Capital Cost (\$) & 33,798 & 33,798 & 42,261 & 34,376 & 34,376 & 70,893 \\
\hline Year 1 Electric Cost (\$) & 14,034 & 14,034 & 13,927 & 13,967 & 13,967 & 13,467 \\
\hline Year 1 Demand Cost (\$) & 28,780 & 28,780 & 28,618 & 28,780 & 28,780 & 28,164 \\
\hline Year 1 Electric Savings (\$) & 13 & 13 & 120 & 80 & 80 & 580 \\
\hline Year 1 Demand Savings (\$) & 2,956 & 2,956 & 3,118 & 2,956 & 2,956 & 3,572 \\
\hline Annual Resiliency Savings (\$) & - & 232 & 232 & - & 1,632 & 1,632 \\
\hline LCC (\$) & 941,764 & 934,415 & 946,233 & 941,186 & 942,942 & 961,257 \\
\hline NPV (\$) & 430 & 11,818 & 0.00 & 1,008 & 27,644 & 9,329 \\
\hline SPP (years) & 11.39 & 9.38 & 12.18 & 11.32 & 7.37 & 12.26 \\
\hline Diesel Fuel Used (gallons) & 7.75 & 7.75 & 7.47 & 41.28 & 18.11 & 30.22 \\
\hline $\begin{array}{l}\text { Incentive Required to get to } \\
\mathrm{NPV}=0(\%)\end{array}$ & $0 \%$ & $0 \%$ & $0 \%$ & $0 \%$ & $0 \%$ & $0 \%$ \\
\hline
\end{tabular}


Table D-15. Cooling Center Scenario 4: Generator Sized to Meet Resiliency Needs

\begin{tabular}{|c|c|c|c|c|}
\hline Scenario Number & 4.1.a & 4.1.b & 4.2.a & 4.2.b \\
\hline Description & $\begin{array}{r}2 \text { hour outage, } \\
\text { no resiliency } \\
\text { value }\end{array}$ & $\begin{array}{r}2 \text { hour outage, } \\
\text { with resiliency } \\
\text { value }\end{array}$ & $\begin{array}{r}22 \text { hour } \\
\text { outage, no } \\
\text { resiliency value }\end{array}$ & $\begin{array}{r}22 \text { hour outage, } \\
\text { with resiliency } \\
\text { value }\end{array}$ \\
\hline Outage START (hour of year) & 5220 & 5220 & 5172 & 5172 \\
\hline Outage STOP (hour of year) & 5226 & 5226 & 5222 & 5222 \\
\hline Resiliency Value (\$/hour) & 0 & 32.02 & 0 & 32.02 \\
\hline Outage Duration (hours) & 7.25 & 7.25 & 50.96 & 50.96 \\
\hline PV Size (kW-DC) & 0 & 0 & 0 & 0 \\
\hline Battery Size (kWh) & 0.00 & 0.00 & 0.00 & 0.00 \\
\hline Battery Size (kW) & 0.00 & 0.00 & 0.00 & 0.00 \\
\hline Diesel Generator Size (kW) & 12.40 & 12.40 & 12.40 & 12.40 \\
\hline PV Cost (\$) & 0 & 0 & 0 & 0 \\
\hline PV Cost Less NY Sun incentive (\$) & 0 & 0 & 0 & 0 \\
\hline Battery Cost (\$) & 0 & 0 & 0 & 0 \\
\hline Generator Cost (\$) & 18,600 & 18,600 & 18,600 & 18,600 \\
\hline Total Capital Cost (\$) & 18,600 & 18,600 & 18,600 & 18,600 \\
\hline Year 1 Electric Cost (\$) & 14,043 & 14,043 & 13,986 & 13,986 \\
\hline Year 1 Demand Cost (\$) & 31,735 & 31,735 & 31,735 & 31,735 \\
\hline Year 1 Electric Savings (\$) & 4 & 4 & 61 & 61 \\
\hline Year 1 Demand Savings (\$) & 1 & 1 & 1 & 1 \\
\hline Annual Resiliency Savings (\$) & - & 232 & - & 1,632 \\
\hline LCC (\$) & 967,605 & 967,605 & 966,440 & 968,024 \\
\hline NPV (\$) & $(25,411)$ & $(21,372)$ & $(24,246)$ & 2,562 \\
\hline SPP (years) & 4133.33 & 78.60 & 302.44 & 10.98 \\
\hline Diesel Fuel Used (gallons) & 9.2 & 9.2 & 47.55 & 47.55 \\
\hline $\begin{array}{l}\text { Incentive Required to get to NPV=0 } \\
\text { (\%) }\end{array}$ & N/A & N/A & $\mathrm{N} / \mathrm{A}$ & $\mathrm{N} / \mathrm{A}$ \\
\hline
\end{tabular}

